\title{
System Study: \\ Residual Heat Removal 1998-2014
}

\author{
John A. Schroeder
}

December 2015

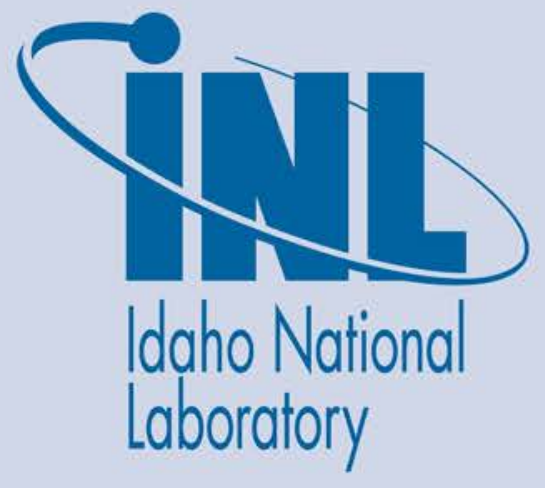

The INL is a U.S. Department of Energy National Laboratory operated by Battelle Energy Alliance 
NOTICE

This information was prepared as an account of work sponsored by an agency of the U.S. Government. Neither the U.S. Government nor any agency thereof, nor any of their employees, makes any warranty, express or implied, or assumes any legal liability or responsibility for any third party's use, or the results of such use, of any information, apparatus, product, or process disclosed herein, or represents that its use by such third party would not infringe privately owned rights. The views expressed herein are not necessarily those of the U.S. Nuclear Regulatory Commission. 


\title{
System Study: Residual Heat Removal 1998-2014
}

\author{
John A. Schroeder
}

Update Completed December 2015

Idaho National Laboratory

Risk Assessment and Management Services Department Idaho Falls, Idaho 83415

http://www.inl.gov

Prepared for the Division of Risk Assessment Office of Nuclear Regulatory Research

U.S. Nuclear Regulatory Commission NRC Agreement Number NRC-HQ-14-D-0018 



\begin{abstract}
This report presents an unreliability evaluation of the residual heat removal (RHR) system in two modes of operation (low-pressure injection in response to a large loss-of-coolant accident and post-trip shutdown-cooling) at 104 U.S. commercial nuclear power plants. Demand, run hours, and failure data from fiscal year 1998 through 2014 for selected components were obtained from the Institute of Nuclear Power Operations (INPO) Consolidated Events Database (ICES). The unreliability results are trended for the most recent 10-year period while yearly estimates for system unreliability are provided for the entire active period. No statistically significant increasing trends were identified in the RHR results. A highly statistically significant decreasing trend was observed for the RHR injection mode start-only unreliability. Statistically significant decreasing trends were observed for RHR shutdown cooling mode start-only unreliability and RHR shutdown cooling model 24-hour unreliability.
\end{abstract}


System Study

Residual Heat Removal
2014 Update

December 2015 


\section{CONTENTS}

ABSTRACT

ACRONYMS

ix

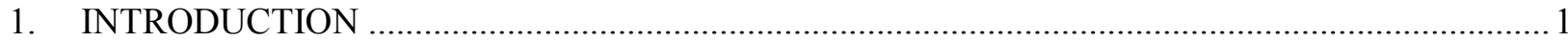

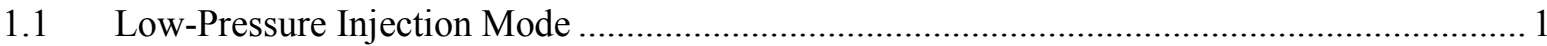

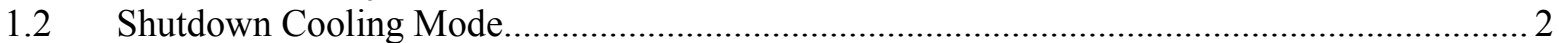

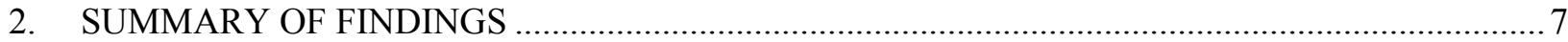

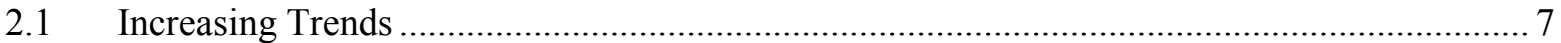

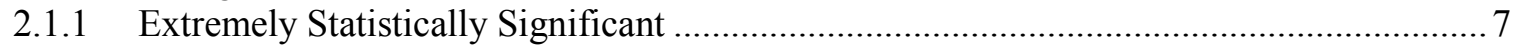

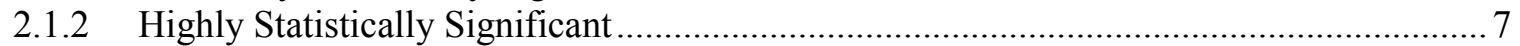

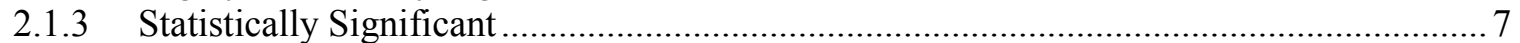

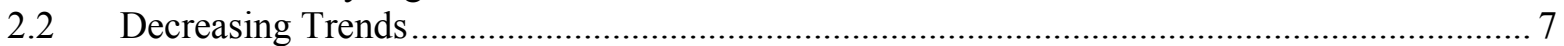

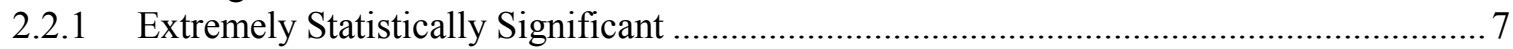

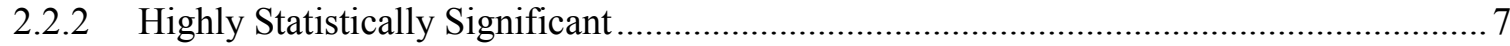

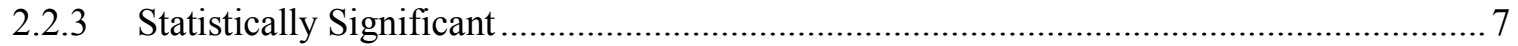

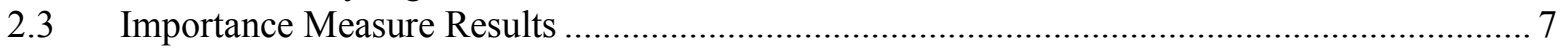

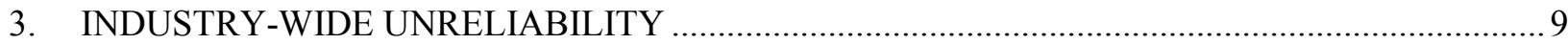

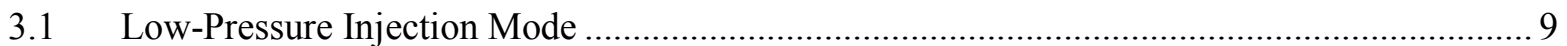

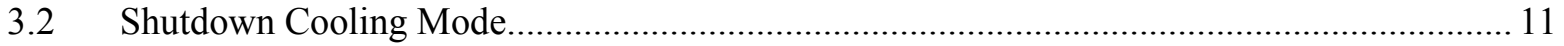

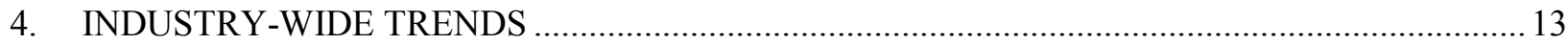

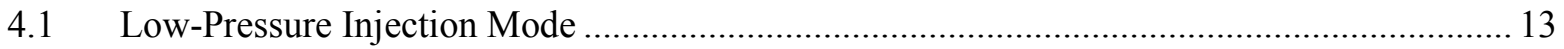

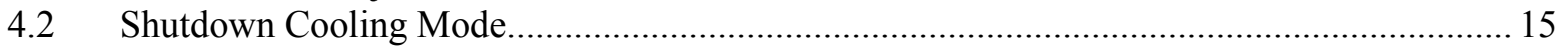

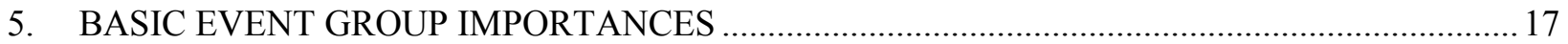

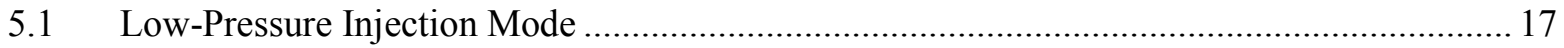

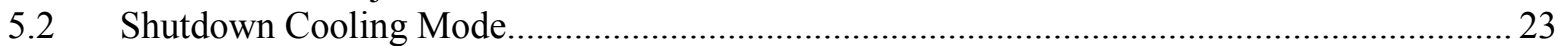

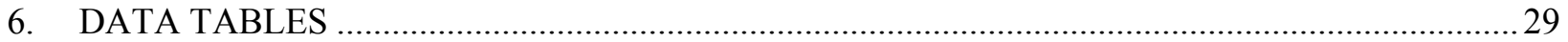

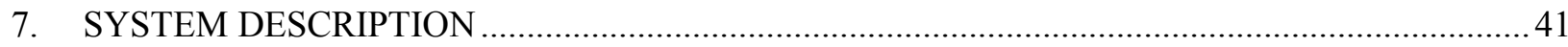

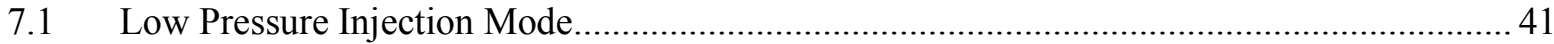

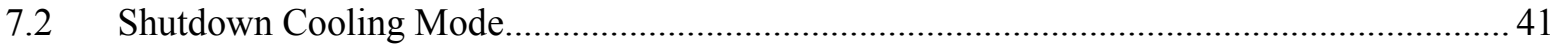

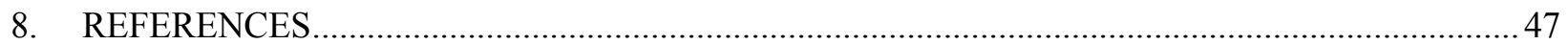




\section{FIGURES}

1. RHR low-pressure injection mode start-only mission unreliability for class and industry-wide groupings.

2. RHR low-pressure injection mode 8-hour mission unreliability for class and industry-wide groupings.

3. RHR shutdown cooling mode start-only mission unreliability for class and industry-wide groupings.

4. RHR shutdown cooling mode 24-hour mission unreliability for class and industry-wide groupings.

5. Trend of RHR (injection mode) system unreliability (start-only model), as a function of fiscal year.

6. Trend of RHR (injection mode) system unreliability (8-hour model), as a function of fiscal year.

7. Trend of RHR shutdown cooling mode system unreliability (start-only model), as a function of fiscal year.

8. Trend of RHR shutdown cooling mode system unreliability (24-hour model), as a function of fiscal year.

9. RHR (injection mode) industry-wide basic event group importances.

10. RHR (injection mode) two pump BW basic event group importances

11. RHR (injection mode) two pumps CE basic event group importances

12. RHR (injection mode) two pumps GE basic event group importances.

13. RHR (injection mode) two pumps WE basic event group importances.

14. RHR (injection mode) three pumps BW basic event group importances.

15. RHR (injection mode) three pumps GE basic event group importances.

16. RHR (injection mode) three pumps WE basic event group importances.

17. RHR (injection mode) four pumps CE basic event group importances.

18. RHR (injection mode) four pumps GE basic event group importances.

19. RHR shutdown cooling mode industry-wide basic event group importances.

20. RHR shutdown cooling mode direct heat sink, multiple suction path basic event group importances 
21. RHR shutdown cooling mode direct heat sink, single suction path basic event group importances

22. RHR shutdown cooling mode indirect heat sink, multiple suction paths basic event group importances.

23. RHR shutdown cooling mode indirect heat sink, single suction path basic event group importances.

24. RHR shutdown cooling mode no suction modeled basic event group importances.

25. RHR shutdown cooling mode single train basic event group importances........................................ 26

26. RHR shutdown cooling mode single use SDC system basic event group importances...................... 27

27. Generic depiction of the RHR system.

\section{TABLES}

1. RHR low-pressure injection class definitions.......................................................................... 2

2. RHR shutdown cooling mode design class definitions............................................................ 3

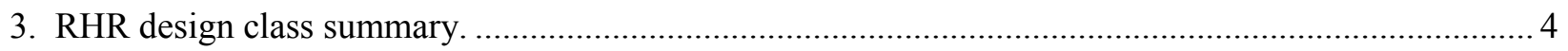

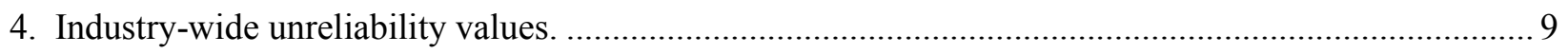

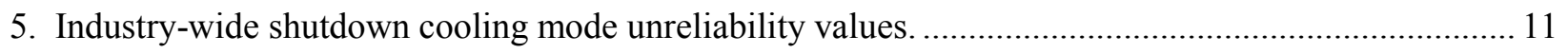

6. RHR model basic event importance group descriptions............................................................ 17

7. Plot data for RHR low-pressure injection mode start-only trend, Figure 5 ..................................... 29

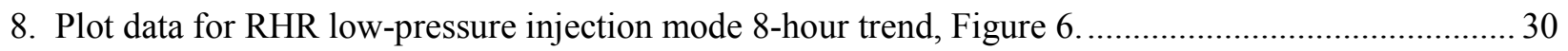

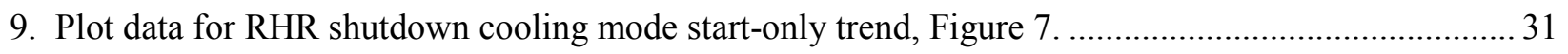

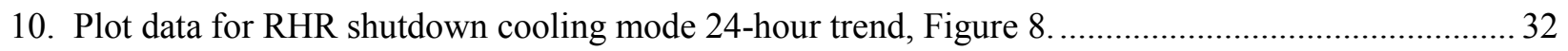

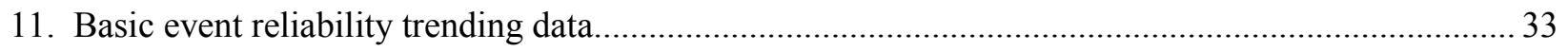

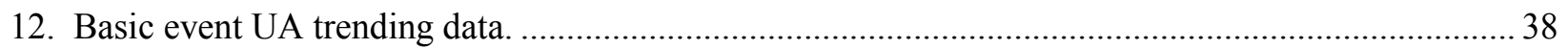

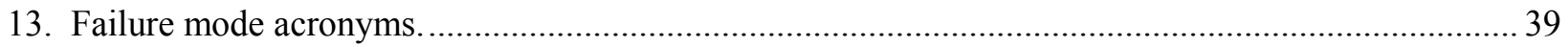

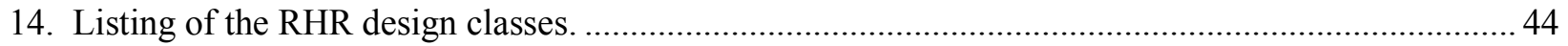


System Study

Residual Heat Removal
2014 Update December 2015 


\section{ACRONYMS}

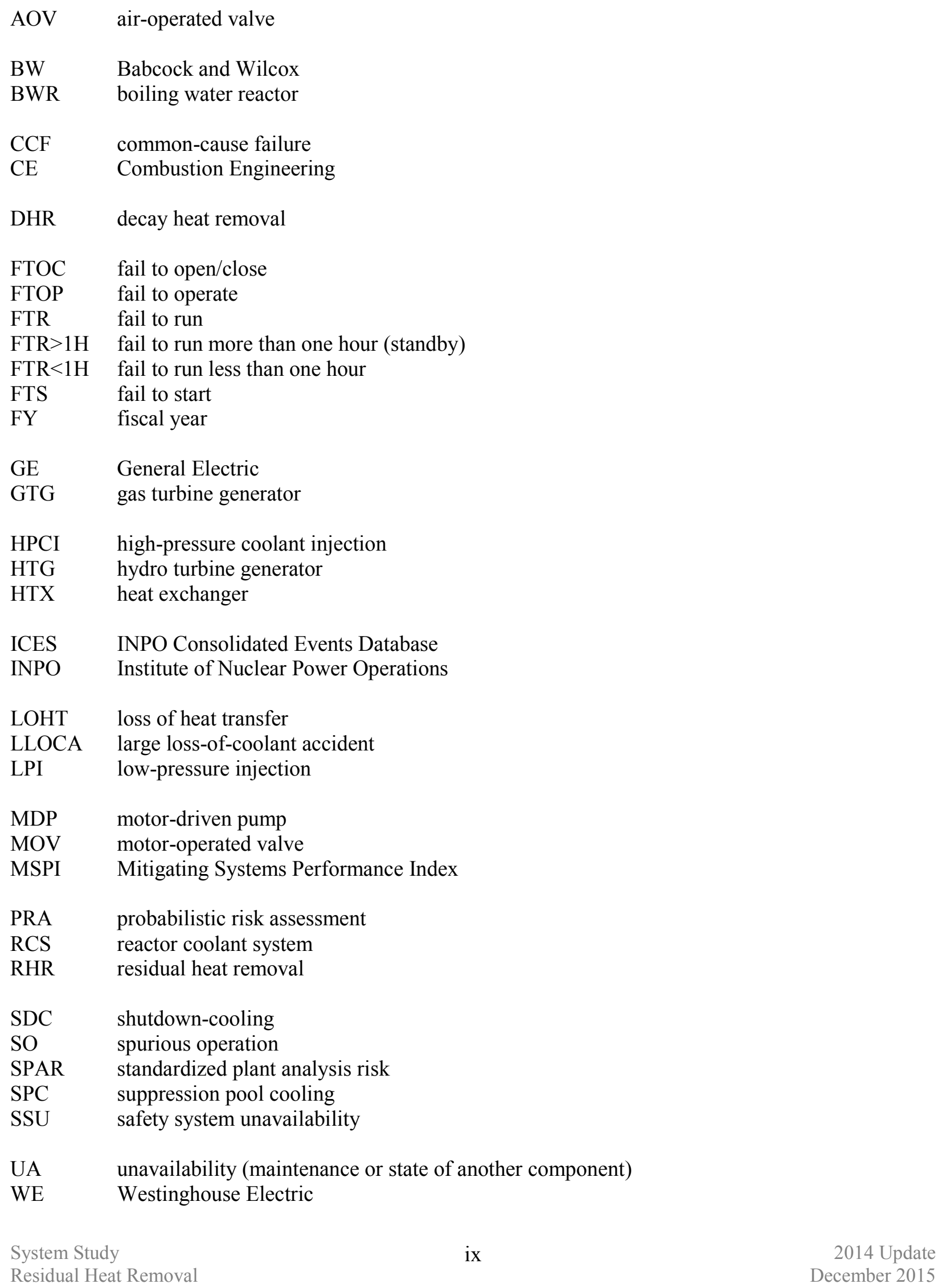


System Study

Residual Heat Removal
2014 Update

December 2015 


\section{System Study: Residual Heat Removal 1998-2014}

\section{INTRODUCTION}

The residual heat removal (RHR) system is typically a multiple use system with modes of operation for low-pressure injection, shutdown cooling, suppression pool or containment sump cooling, and/or containment spray. Some plants have dedicated systems to accomplish one or more of these modes. This report presents an unreliability evaluation over time of the RHR system in two modes of operation-lowpressure injection (LPI) in response to a large loss-of-coolant accident (LLOCA) and post-trip shutdowncooling (SDC) - at 104 U.S. commercial nuclear power plants.

Demand, run hours, and failure data from fiscal year (FY)-98 through FY-14 for selected components in the RHR system were obtained from the Institute of Nuclear Power Operations (INPO) Consolidated Events Database (ICES). Train unavailability data (outages from test or maintenance) were obtained from the Reactor Oversight Process Safety System Unavailability (SSU) database (FY-98 through FY-01) and the Mitigating Systems Performance Index (MSPI) database (FY-02 through FY-14). Commoncause failure (CCF) data used in the models are from the 2010 update to the CCF database. The system unreliability results are trended for the most recent 10-year period while yearly estimates for system unreliability are provided for the entire active period.

This report does not attempt to estimate basic event values for use in a probabilistic risk assessment (PRA). Suggested values for such use are presented in the 2010 Component Reliability Update (Reference 1), which is an update to Reference 2 (NUREG/CR-6928). Baseline RHR unreliability results using basic event values from that report are summarized in Section 3. Trend results for RHR (using system-specific data) are presented in Section 4. Similar to previous system study updates, Section 5 contains importance information (using the baseline results from Section 3), and Section 7 describes the RHR system.

All models include failures due to unavailability while in test or maintenance. Human error has not been included in the SPAR model logic. Human actions for various recovery actions are included. An overview of the trending methods, glossary of terms, and abbreviations can be found in the Overview and Reference document on the Reactor Operational Experience Results and Databases web page.

\subsection{Low-Pressure Injection Mode}

Table 1 shows the definitions of the design classes used in the low-pressure injection mode of operation sections of this report. For each plant the corresponding SPAR model (version model indicated in Table 3 was used in the calculations. The low-pressure injection mode represents the use of the system as it is normally lined up during power operations. The RHR system in low-pressure injection mode is an automatically initiated event.

The RHR is categorized by the number of redundant low-pressure injection pumps and the plant vendor design as the most significant differences noted between systems at plants for the low-pressure injection mode. Table 3 summarizes the plants and their LPI classes.

Two versions of the low-pressure injection mode models for the RHR system are calculated. The RHR start-only model is the SPAR RHR low-pressure injection mode model modified by setting all failto-run basic events to zero (False), setting all recovery events to False, all room cooling events to False, and all pump cooling events to False. The 8-hour mission model includes all basic events in the SPAR RHR low-pressure injection mode model. 
Table 1. RHR low-pressure injection class definitions.

\begin{tabular}{llc}
\hline RHR Injection Class & \multicolumn{1}{c}{ Description } & $\begin{array}{c}\text { Number of } \\
\text { Plants }\end{array}$ \\
\hline 2 pumps; BW & Two RHR pump Babcock and Wilcox (BW) Design & 4 \\
2 pumps; CE & Two RHR pump Combustion Engineering (CE) Design & 11 \\
2 pumps; GE & Two RHR pump General Electric (GE) Design & 9 \\
2 pumps; WE & Two RHR pump Westinghouse (WE) Design & 46 \\
3 pumps; BW & Three RHR pump Babcock and Wilcox Design & 3 \\
3 pumps; GE & Three RHR pump General Electric Design & 4 \\
3 pumps; WE & Three RHR pump Westinghouse Design & 2 \\
4 pumps; CE & Four RHR pump Combustion Engineering Design & 3 \\
4 pumps; GE & Four RHR pump General Electric Design & 22 \\
\hline Total & & 104 \\
\hline
\end{tabular}

\subsection{Shutdown Cooling Mode}

Table 2 shows the definitions of the design classes used in the shutdown-cooling mode of operation sections of this report. For each plant the corresponding Standardized Plant Analysis Risk (SPAR) model (version model indicated in Table 3) was used in the calculations.

The shutdown-cooling mode represents the most challenging (more risk-significant at PWRs than in BWRs) use of the equipment since the heat exchangers are required to function and valves must be repositioned to initiate the cooldown function. The RHR system in shutdown cooling mode is a manually initiated event. Each fault tree modeling the shutdown-cooling mode of RHR includes a human action basic event to model the initiation. This basic event always comes out as the most important basic event in the model. To evaluate the system in more detail, the human action to initiate shutdown cooling was trimmed from the fault tree.

The RHR shutdown-cooling mode is categorized by the heat sink method in this report as the most significant difference noted between systems at plants. The direct heat sink takes sensible heat from the reactor coolant system (RCS) and transfers it directly to the ultimate heat sink (a variation of a service water system either dedicated or shared with other safety systems). The indirect heat sink transfers sensible heat to a closed cooling water system, which in turn transfers the heat to the ultimate heat sink. Table 3 summarizes the plants and their classes.

Two variations of the shutdown-cooling modes for the RHR system are calculated. The RHR startonly variation is the SPAR RHR shutdown cooling model modified by setting all fail-to-run basic events to zero (False), setting all recovery events to False, all room cooling events to False, and all pump cooling events to False. The 24-hour mission variation includes all basic events in the SPAR RHR shutdowncooling model. 
Table 2. RHR shutdown cooling mode design class definitions.

\begin{tabular}{llc}
\hline $\begin{array}{c}\text { RHR Shutdown } \\
\text { Cooling Design Class }\end{array}$ & \multicolumn{1}{c}{$\begin{array}{c}\text { Description } \\
\text { Direct-Multiple }\end{array}$} & $\begin{array}{c}\text { Number of } \\
\text { Plants }\end{array}$ \\
\hline Direct-Single & Direct heat sink, uses multiple suction paths & 5 \\
Indirect-Multiple & Direct heat sink, uses a single suction path & 29 \\
Indirect-Single & Indirect heat sink, uses multiple suction paths & 24 \\
No suction modeled & Indirect heat sink, uses a single suction path & Models do not include the suction path valves (model \\
Suppression pool cooling only) & 31 \\
Single Train & Only one train is used in the model & 4 \\
Single Use & Plants with a single-use SDC system & 1 \\
Total & & 10 \\
\hline
\end{tabular}


Table 3. RHR design class summary.

\begin{tabular}{|c|c|c|c|c|c|c|c|}
\hline Plant & Version & $\begin{array}{l}\text { Injection } \\
\text { Class }\end{array}$ & $\begin{array}{c}\text { Shutdown } \\
\text { Cooling Class }\end{array}$ & Plant & Version & $\begin{array}{l}\text { Injection } \\
\text { Class }\end{array}$ & $\begin{array}{c}\text { Shutdown } \\
\text { Cooling Class }\end{array}$ \\
\hline Arkansas 1 & 8.19 & 2 pumps; BW & Direct-Single & Indian Point 3 & 8.20 & 2 pumps; WE & Indirect-Single \\
\hline Arkansas 2 & 8.21 & 2 pumps; CE & Direct-Single & Kewaunee & 8.20 & 2 pumps; WE & Indirect-Multiple \\
\hline Beaver Valley 1 & 8.22 & 2 pumps; WE & Single Use & La Salle 1 & 8.21 & 2 pumps; GE & Direct-Single \\
\hline Beaver Valley 2 & 8.23 & 2 pumps; WE & Single Use & La Salle 2 & 8.21 & 2 pumps; GE & Direct-Single \\
\hline Braidwood 1 & 8.21 & 2 pumps; WE & Indirect-Multiple & Limerick 1 & 8.20 & 4 pumps; GE & Direct-Single \\
\hline Braidwood 2 & 8.21 & 2 pumps; WE & Indirect-Multiple & Limerick 2 & 8.19 & 4 pumps; GE & Direct-Single \\
\hline Browns Ferry 1 & 8.22 & 4 pumps; GE & Direct-Single & McGuire 1 & 8.20 & 2 pumps; WE & Indirect-Single \\
\hline Browns Ferry 2 & 8.22 & 4 pumps; GE & Direct-Single & McGuire 2 & 8.20 & 2 pumps; WE & Indirect-Single \\
\hline Browns Ferry 3 & 8.18 & 4 pumps; GE & Direct-Single & Millstone 2 & 8.17 & 2 pumps; CE & Indirect-Single \\
\hline Brunswick 1 & 8.20 & 4 pumps; GE & Direct-Single & Millstone 3 & 8.20 & 2 pumps; WE & Indirect-Multiple \\
\hline Brunswick 2 & 8.20 & 4 pumps; GE & Direct-Single & Monticello & 8.20 & 4 pumps; GE & Direct-Single \\
\hline Byron 1 & 8.21 & 2 pumps; WE & Indirect-Multiple & Nine Mile Pt. 1 & 8.21 & 3 pumps; GE & Single Use \\
\hline Byron 2 & 8.21 & 2 pumps; WE & Indirect-Multiple & Nine Mile Pt. 2 & 8.17 & 2 pumps; GE & Direct-Single \\
\hline Callaway & 8.21 & 2 pumps; WE & Indirect-Multiple & North Anna 1 & 8.20 & 2 pumps; WE & Single Use \\
\hline Calvert Cliffs 1 & 8.22 & 2 pumps; CE & Indirect-Single & North Anna 2 & 8.20 & 2 pumps; WE & Single Use \\
\hline Calvert Cliffs 2 & 8.21 & 2 pumps; CE & Indirect-Single & Oconee 1 & 8.19 & 3 pumps; BW & Indirect-Single \\
\hline Catawba 1 & 8.20 & 2 pumps; WE & Indirect-Single & Oconee 2 & 8.19 & 3 pumps; BW & Indirect-Single \\
\hline Catawba 2 & 8.20 & 2 pumps; WE & Indirect-Single & Oconee 3 & 8.19 & 3 pumps; BW & Indirect-Single \\
\hline Clinton 1 & 8.17 & 2 pumps; GE & Direct-Single & Oyster Creek & 8.22 & 3 pumps; GE & Single Use \\
\hline Columbia 2 & 8.16 & 2 pumps; GE & Direct-Single & Palisades & 8.20 & 2 pumps; CE & Indirect-Single \\
\hline Comanche Peak 1 & 8.21 & 2 pumps; WE & Indirect-Multiple & Palo Verde 1 & 8.20 & 4 pumps; CE & Direct-Multiple \\
\hline Comanche Peak 2 & 8.21 & 2 pumps; WE & Indirect-Multiple & Palo Verde 2 & 8.20 & 4 pumps; CE & Direct-Multiple \\
\hline Cook 1 & 8.20 & 2 pumps; WE & Indirect-Single & Palo Verde 3 & 8.20 & 4 pumps; CE & Direct-Multiple \\
\hline Cook 2 & 8.20 & 2 pumps; WE & Indirect-Single & Peach Bottom 2 & 8.25 & 4 pumps; GE & Direct-Single \\
\hline Cooper & 8.22 & 4 pumps; GE & Direct-Single & Peach Bottom 3 & 8.21 & 4 pumps; GE & Direct-Single \\
\hline Crystal River 3 & 8.16 & 2 pumps; BW & Direct-Single & Perry & 8.19 & 2 pumps; GE & Indirect-Single \\
\hline Davis-Besse & 8.19 & 2 pumps; BW & Indirect-Single & Pilgrim & 8.21 & 4 pumps; GE & \\
\hline Diablo Canyon 1 & 8.19 & 2 pumps; WE & Indirect-Single & & & & \\
\hline Diablo Canyon 2 & 8.19 & 2 pumps; WE & Indirect-Single & Point Beach 1 & 8.20 & 2 pumps; WE & Indirect-Single \\
\hline Dresden 2 & 8.18 & 3 pumps; GE & Single Use & Point Beach 2 & 8.20 & 2 pumps; WE & Indirect-Single \\
\hline Dresden 3 & 8.18 & 3 pumps; GE & Single Use & Prairie Island 1 & 8.19 & 2 pumps; WE & Direct-Multiple \\
\hline Duane Arnold & 8.22 & 4 pumps; GE & Direct-Single & Prairie Island 2 & 8.19 & 2 pumps; WE & Direct-Multiple \\
\hline Farley 1 & 8.18 & 2 pumps; WE & Indirect-Multiple & Quad Cities 1 & 8.18 & 4 pumps; GE & Direct-Single \\
\hline Farley 2 & 8.18 & 2 pumps; WE & Indirect-Multiple & Quad Cities 2 & 8.18 & 4 pumps; GE & Direct-Single \\
\hline Fermi 2 & 8.20 & 4 pumps; GE & Direct-Single & River Bend & 8.20 & 2 pumps; GE & Direct-Single \\
\hline \multirow[t]{2}{*}{ FitzPatrick } & \multirow[t]{2}{*}{8.17} & \multirow[t]{2}{*}{4 pumps; GE } & \multirow{2}{*}{$\begin{array}{l}\text { No suction } \\
\text { modeled }\end{array}$} & Robinson 2 & 8.17 & 2 pumps; WE & Indirect-Single \\
\hline & & & & Salem 1 & 8.20 & 2 pumps; WE & Indirect-Single \\
\hline Fort Calhoun & 8.20 & 2 pumps; CE & Indirect-Single & Salem 2 & 8.20 & 2 pumps; WE & Indirect-Single \\
\hline Ginna & 8.23 & 2 pumps; WE & Indirect-Single & San Onofre 2 & 8.22 & 2 pumps; CE & Indirect-Multiple \\
\hline Grand Gulf & 8.22 & 2 pumps; GE & Direct-Single & San Onofre 3 & 8.22 & 2 pumps; CE & Indirect-Multiple \\
\hline Harris & 8.23 & 2 pumps; WE & Indirect-Multiple & Seabrook & 8.20 & 2 pumps; WE & Indirect-Multiple \\
\hline Hatch 1 & 8.20 & 4 pumps; GE & Direct-Single & Sequoyah 1 & 8.16 & 2 pumps; WE & Indirect-Single \\
\hline Hatch 2 & 8.20 & 4 pumps; GE & Direct-Single & Sequoyah 2 & 8.16 & 2 pumps; WE & Indirect-Single \\
\hline Hope Creek & 8.18 & 2 pumps; GE & Direct-Single & South Texas 1 & 8.17 & 3 pumps; WE & Indirect-Multiple \\
\hline Indian Point 2 & 8.19 & 2 pumps; WE & Indirect-Single & South Texas 2 & 8.17 & 3 pumps; WE & Indirect-Multiple \\
\hline
\end{tabular}


Table 3. (continued).

\begin{tabular}{|c|c|c|c|c|c|c|c|}
\hline Plant & Version & $\begin{array}{l}\text { Injection } \\
\text { Class }\end{array}$ & $\begin{array}{c}\text { Shutdown } \\
\text { Cooling Class }\end{array}$ & Plant & Version & $\begin{array}{l}\text { Injection } \\
\text { Class }\end{array}$ & $\begin{array}{c}\text { Shutdown } \\
\text { Cooling Class }\end{array}$ \\
\hline St. Lucie 1 & 8.19 & 2 pumps; CE & Indirect-Multiple & Turkey Point 3 & 8.20 & 2 pumps; WE & Indirect-Single \\
\hline St. Lucie 2 & 8.19 & 2 pumps; CE & Indirect-Multiple & Turkey Point 4 & 8.20 & 2 pumps; WE & Indirect-Single \\
\hline Summer & 8.23 & 2 pumps; WE & Indirect-Multiple & Vermont Yankee & 8.19 & 4 pumps; GE & Direct-Single \\
\hline Surry 1 & 8.19 & 2 pumps; WE & Single Use & Vogtle 1 & 8.21 & 2 pumps; WE & Indirect-Multiple \\
\hline Surry 2 & 8.15 & 2 pumps; WE & Single Use & Vogtle 2 & 8.21 & 2 pumps; WE & Indirect-Multiple \\
\hline \multirow[t]{2}{*}{ Susquehanna 1} & \multirow[t]{2}{*}{8.23} & \multirow[t]{2}{*}{4 pumps; GE } & \multirow{2}{*}{$\begin{array}{l}\text { No suction } \\
\text { modeled }\end{array}$} & Waterford 3 & 8.16 & 2 pumps; CE & Indirect-Multiple \\
\hline & & & & Watts Bar 1 & 8.16 & 2 pumps; WE & Indirect-Single \\
\hline Susquehanna 2 & 8.21 & 4 pumps; GE & $\begin{array}{l}\text { No suction } \\
\text { modeled }\end{array}$ & Wolf Creek & 8.20 & 2 pumps; WE & Indirect-Multiple \\
\hline
\end{tabular}


System Study

Residual Heat Removal
2014 Update

December 2015 


\section{SUMMARY OF FINDINGS}

The results of this RHR system unreliability study are summarized in this section. Of particular interest is the existence of any statistically significant ${ }^{\mathrm{a}}$ increasing trends. In this update no statistically significant increasing trends were identified in the RHR unreliability trend results.

\subsection{Increasing Trends}

\subsubsection{Extremely Statistically Significant}

- None.

\subsubsection{Highly Statistically Significant}

- None

\subsubsection{Statistically Significant}

- None.

\subsection{Decreasing Trends}

\subsubsection{Extremely Statistically Significant}

- None

\subsubsection{Highly Statistically Significant}

- Start-only RHR injection mode unreliability (Figure 5) was found to be decreasing.

\subsubsection{Statistically Significant}

- Start-only RHR shutdown cooling mode unreliability (Figure 7) was found to be decreasing.

- RHR shutdown cooling mode unreliability (Figure 8) for a 24-hour mission was found to be decreasing.

\subsection{Importance Measure Results}

The industry-wide RHR low-pressure injection mode start-only and 8-hour basic event group importances were evaluated and are shown in Figure 9. In both cases, the leading contributors to RHR LPI system unreliability are the RHR motor-driven pumps followed by the injection flow path. Section 5 shows importance charts for each RHR LPI class.

The industry-wide RHR shutdown-cooling mode start-only and 24-hour basic event group importances were evaluated and are shown in Figure 19. In both cases, the leading contributor to RHR SDC system unreliability in the shutdown-cooling mode is the human action to reposition the valves in the suction flow path followed by random failures of the injection flow path. The suction was the third most important segment. Section 5 shows importance charts for each RHR SDC class. For those plants with a single suction source, the suction segment importance increases significantly. For those plants that have

a. Statistically significant is defined in terms of the 'p-value.' A p-value is a probability indicating whether to accept or reject the null hypothesis that there is no trend in the data. P-values of less than or equal to 0.05 indicate that we are $95 \%$ confident that there is a trend in the data (reject the null hypothesis of no trend.) By convention, we use the "Michelin Guide" scale: p-value $<0.05$ (statistically significant), p-value $<0.01$ (highly statistically significant); pvalue $<0.001$ (extremely statistically significant). 
multiple suction sources, the pump importance increases since the suction segment importance decreases. The distinction between the heat sink types (direct versus indirect) is not very large. This is due to the standby nature of most of the direct heat sink systems and the normally operating nature of the indirect heat sink systems. 


\section{INDUSTRY-WIDE UNRELIABILITY}

\subsection{Low-Pressure Injection Mode}

The RHR low-pressure injection mode fault trees (not all SPAR models label the appropriate fault tree as 'LPI', Table 14 lists the fault tree that was evaluated for this report) from the SPAR models were evaluated for each of the 104 operating U.S. commercial pressurized water nuclear power plants with an RHR system.

The industry-wide unreliability of the RHR system has been estimated for two modes of operation. A start-only model and an 8-hour mission model were evaluated. The uncertainty distributions for RHR show both plant design variability and parameter uncertainty while using industry-wide component failure data (FY-98 through FY-10). ${ }^{\mathrm{a}}$ Table 4 shows the percentiles and mean of the aggregated sample data (Latin hypercube, 1000 samples for each model) collected from the uncertainty calculations of the RHR fault trees in the SPAR models. In Figure 1 and Figure 2, the 5th and 95th percentiles and mean point estimates are shown for each RHR class and for the industry.

In Figure 1 and Figure 2, the width of the distribution for a class is affected by the differences in the plant modeling and the parameter uncertainty used in the models. Because the width is affected by the plant modeling, the width is also affected by the number of different plant models in a class. For those classes with very few plants that share a design, the width can be very small.

Table 4. Industry-wide unreliability values.

\begin{tabular}{llcccc}
\hline \multicolumn{1}{c}{ Model } & RHR Grouping & $\begin{array}{c}\text { Lower } \\
\mathbf{( 5 \% )}\end{array}$ & Median & Mean & $\begin{array}{c}\text { Upper } \\
\mathbf{( 9 5 \% )}\end{array}$ \\
\hline Start-only & Industry & $7.08 \mathrm{E}-06$ & $4.95 \mathrm{E}-05$ & $2.60 \mathrm{E}-04$ & $8.57 \mathrm{E}-04$ \\
& 2 pumps; BW & $3.08 \mathrm{E}-05$ & $1.77 \mathrm{E}-04$ & $3.42 \mathrm{E}-04$ & $1.09 \mathrm{E}-03$ \\
& 2 pumps; CE & $1.59 \mathrm{E}-05$ & $5.74 \mathrm{E}-05$ & $9.27 \mathrm{E}-04$ & $5.77 \mathrm{E}-03$ \\
& 2 pumps; GE & $7.19 \mathrm{E}-06$ & $6.77 \mathrm{E}-05$ & $1.54 \mathrm{E}-04$ & $5.56 \mathrm{E}-04$ \\
& 2 pumps; WE & $8.94 \mathrm{E}-06$ & $4.23 \mathrm{E}-05$ & $1.42 \mathrm{E}-04$ & $8.55 \mathrm{E}-04$ \\
& 3 pumps; BW & $1.43 \mathrm{E}-05$ & $6.49 \mathrm{E}-05$ & $1.23 \mathrm{E}-04$ & $4.00 \mathrm{E}-04$ \\
& 3 pumps; GE & $3.00 \mathrm{E}-07$ & $4.03 \mathrm{E}-05$ & $6.70 \mathrm{E}-05$ & $1.89 \mathrm{E}-04$ \\
& 3 pumps; WE & $1.55 \mathrm{E}-06$ & $8.02 \mathrm{E}-06$ & $1.01 \mathrm{E}-05$ & $2.70 \mathrm{E}-05$ \\
& 4 pumps; CE & $2.05 \mathrm{E}-05$ & $7.06 \mathrm{E}-05$ & $8.73 \mathrm{E}-05$ & $2.09 \mathrm{E}-04$ \\
& 4 pumps; GE & $7.06 \mathrm{E}-06$ & $5.18 \mathrm{E}-05$ & $2.83 \mathrm{E}-04$ & $8.34 \mathrm{E}-04$ \\
& Industry & $1.07 \mathrm{E}-05$ & $6.85 \mathrm{E}-05$ & $3.07 \mathrm{E}-04$ & $8.96 \mathrm{E}-04$ \\
& 2 pumps; BW & $4.52 \mathrm{E}-05$ & $1.94 \mathrm{E}-04$ & $3.64 \mathrm{E}-04$ & $1.13 \mathrm{E}-03$ \\
& 2 pumps; CE & $2.57 \mathrm{E}-05$ & $8.57 \mathrm{E}-05$ & $9.92 \mathrm{E}-04$ & $6.07 \mathrm{E}-03$ \\
& 2 pumps; GE & $8.53 \mathrm{E}-06$ & $1.02 \mathrm{E}-04$ & $2.16 \mathrm{E}-04$ & $7.32 \mathrm{E}-04$ \\
& 2 pumps; WE & $1.64 \mathrm{E}-05$ & $5.80 \mathrm{E}-05$ & $1.50 \mathrm{E}-04$ & $8.62 \mathrm{E}-04$ \\
& 3 pumps; BW & $2.74 \mathrm{E}-05$ & $1.27 \mathrm{E}-04$ & $1.88 \mathrm{E}-04$ & $5.65 \mathrm{E}-04$ \\
& 3 pumps; GE & $1.89 \mathrm{E}-06$ & $4.27 \mathrm{E}-05$ & $6.98 \mathrm{E}-05$ & $1.89 \mathrm{E}-04$ \\
& 3 pumps; WE & $4.80 \mathrm{E}-06$ & $1.38 \mathrm{E}-05$ & $1.60 \mathrm{E}-05$ & $3.41 \mathrm{E}-05$ \\
& 4 pumps; CE & $4.53 \mathrm{E}-05$ & $1.43 \mathrm{E}-04$ & $5.09 \mathrm{E}-04$ & $5.56 \mathrm{E}-04$ \\
\hline 4 pumps; GE & $7.93 \mathrm{E}-06$ & $6.84 \mathrm{E}-05$ & $3.55 \mathrm{E}-04$ & $1.39 \mathrm{E}-03$ \\
\hline
\end{tabular}

a. By using industry-wide component failure data, individual plant performance is not included in the distribution of results. 


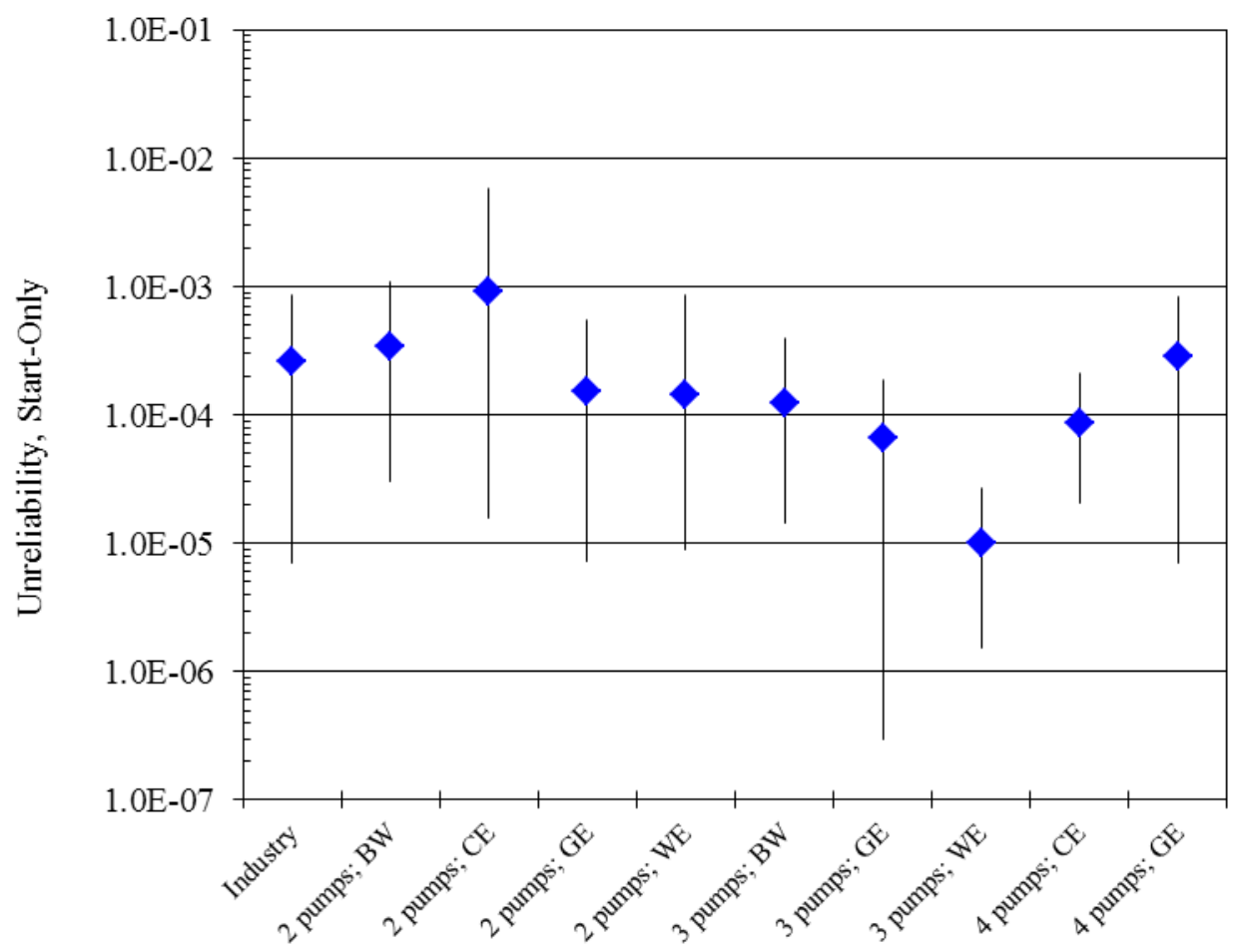

Figure 1. RHR low-pressure injection mode start-only mission unreliability for class and industry-wide groupings.

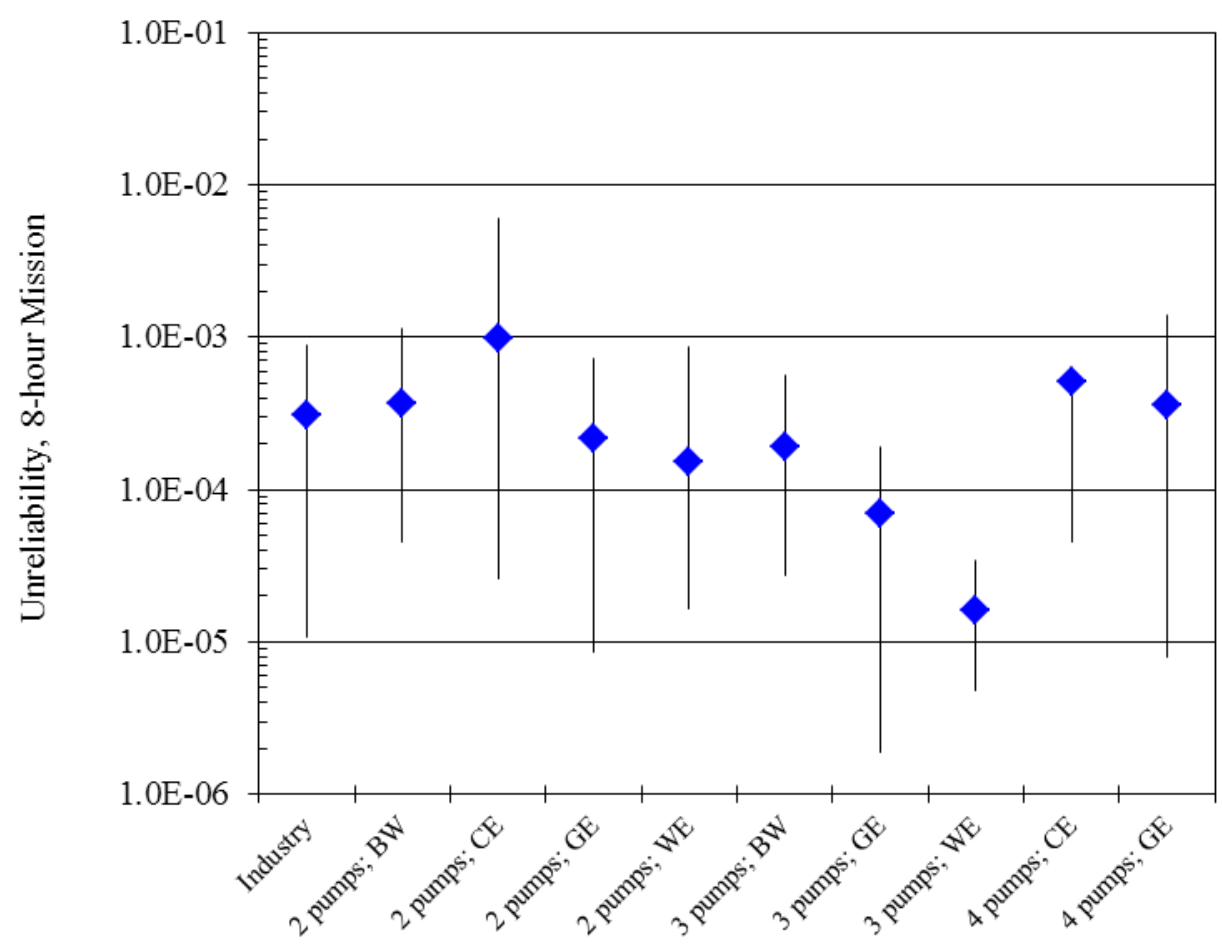

Figure 2. RHR low-pressure injection mode 8-hour mission unreliability for class and industry-wide groupings. 


\subsection{Shutdown Cooling Mode}

The RHR shutdown cooling mode fault trees (not all SPAR models label the appropriate fault tree as 'RHR', Table 14 lists the fault tree that was evaluated for this report) from the SPAR models were evaluated for each of the 104 operating U.S. commercial pressurized water nuclear power plants with an RHR system.

The industry-wide unreliability of the RHR system has been estimated for two modes of operation. A start-only model and a 24-hour mission model were evaluated. The uncertainty distributions for RHR show both plant design variability and parameter uncertainty while using industry-wide component failure data (FY-98 through FY-10). ${ }^{\text {a }}$ Table 5 shows the percentiles and mean of the aggregated sample data (Latin hypercube, 1000 samples for each model) collected from the uncertainty calculations of the RHR fault trees in the SPAR models. In Figure 3 and Figure 4, the 5th and 95th percentiles and mean point estimates are shown for each RHR class and for the industry.

In Figure 3 and Figure 4, the width of the distribution for a class is affected by the differences in the plant modeling and the parameter uncertainty used in the models. Because the width is affected by the plant modeling, the width is also affected by the number of different plant models in a class. For those classes with very few plants that share a design, the width can be very small.

Table 5. Industry-wide shutdown cooling mode unreliability values.

\begin{tabular}{|c|c|c|c|c|c|}
\hline Model & RHR Grouping & $\begin{array}{c}\text { Lower } \\
(5 \%)\end{array}$ & Median & Mean & $\begin{array}{l}\text { Upper } \\
(95 \%)\end{array}$ \\
\hline \multirow[t]{8}{*}{ Start-only } & Industry & $1.80 \mathrm{E}-04$ & $2.81 \mathrm{E}-03$ & $4.39 E-03$ & 1.39E-02 \\
\hline & Direct-Single & $4.08 \mathrm{E}-04$ & $2.38 \mathrm{E}-03$ & $3.03 E-03$ & 7.71E-03 \\
\hline & Direct-Multiple & $5.15 E-04$ & $2.02 E-03$ & $2.99 E-03$ & 8.67E-03 \\
\hline & No Suction Modeled & $2.82 E-06$ & $1.38 \mathrm{E}-04$ & 4.07E-04 & 1.73E-03 \\
\hline & Indirect-Single & $1.13 E-03$ & $4.04 \mathrm{E}-03$ & $5.68 \mathrm{E}-03$ & 1.39E-02 \\
\hline & Indirect-Multiple & $1.20 \mathrm{E}-04$ & 1.57E-03 & $2.72 \mathrm{E}-03$ & $9.06 \mathrm{E}-03$ \\
\hline & Single Use & $7.45 E-04$ & $7.82 E-03$ & $9.81 \mathrm{E}-03$ & $2.41 \mathrm{E}-02$ \\
\hline & Single Train & $9.67 E-03$ & $1.79 \mathrm{E}-02$ & $1.93 E-02$ & $3.47 \mathrm{E}-02$ \\
\hline \multirow[t]{8}{*}{ 24-hour Mission } & Industry & $2.23 E-04$ & 2.93E-03 & $4.57 E-03$ & $1.44 \mathrm{E}-02$ \\
\hline & Direct-Single & $4.22 \mathrm{E}-04$ & $2.44 \mathrm{E}-03$ & $3.11 \mathrm{E}-03$ & $7.78 \mathrm{E}-03$ \\
\hline & Direct-Multiple & $6.84 \mathrm{E}-04$ & 2.33E-03 & $3.56 \mathrm{E}-03$ & $9.40 \mathrm{E}-03$ \\
\hline & No Suction Modeled & 1.37E-05 & $1.79 \mathrm{E}-04$ & $4.35 E-04$ & $1.74 \mathrm{E}-03$ \\
\hline & Indirect-Single & 1.19E-03 & 4.18E-03 & $5.84 \mathrm{E}-03$ & $1.41 \mathrm{E}-02$ \\
\hline & Indirect-Multiple & $1.64 \mathrm{E}-04$ & $1.69 E-03$ & $2.81 \mathrm{E}-03$ & $9.16 \mathrm{E}-03$ \\
\hline & Single Use & $7.64 \mathrm{E}-04$ & $8.28 E-03$ & $1.04 \mathrm{E}-02$ & $2.59 \mathrm{E}-02$ \\
\hline & Single Train & $1.02 \mathrm{E}-02$ & $1.84 \mathrm{E}-02$ & $1.97 \mathrm{E}-02$ & $3.41 \mathrm{E}-02$ \\
\hline
\end{tabular}

a By using industry-wide component failure data, individual plant performance is not included in the distribution of results. 


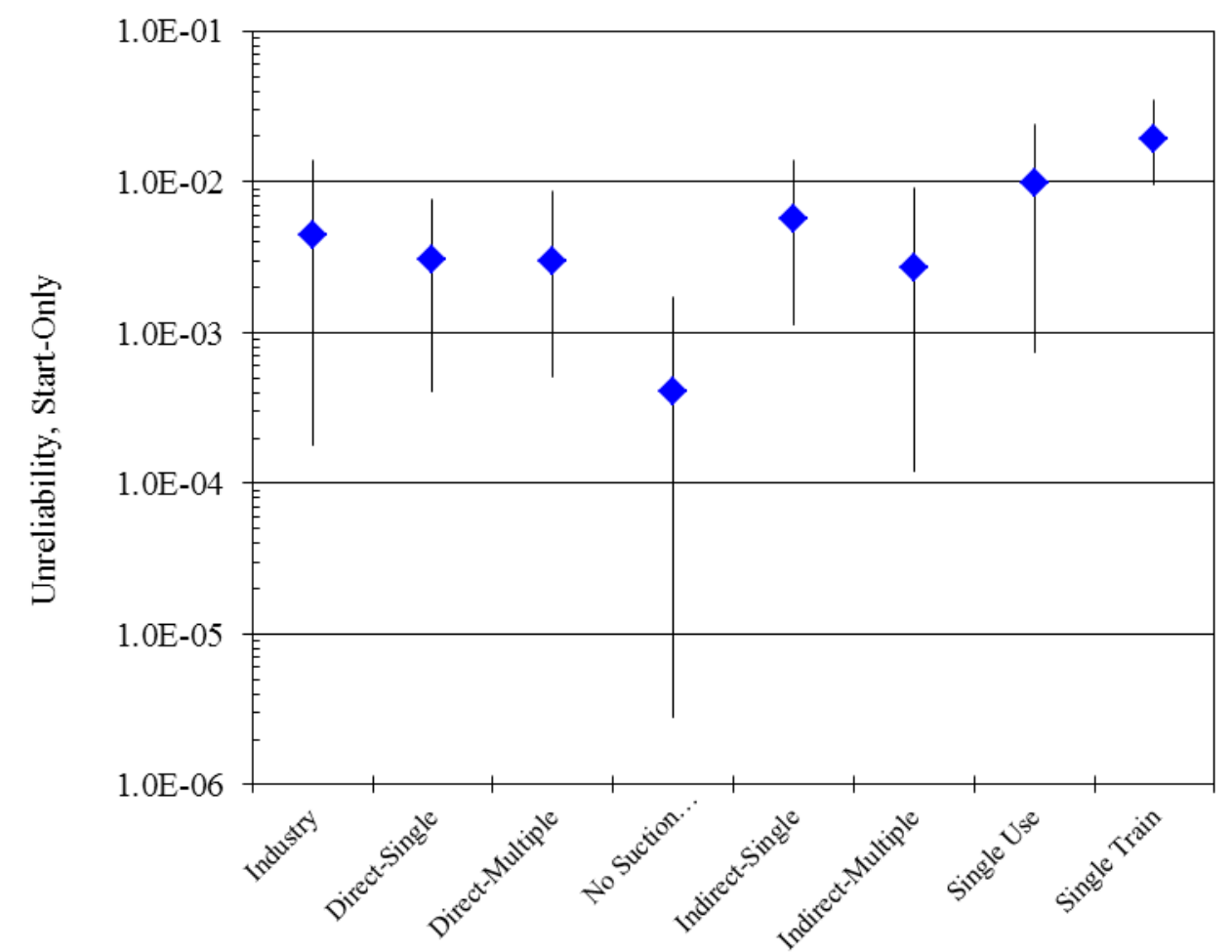

Figure 3. RHR shutdown cooling mode start-only mission unreliability for class and industry-wide groupings.

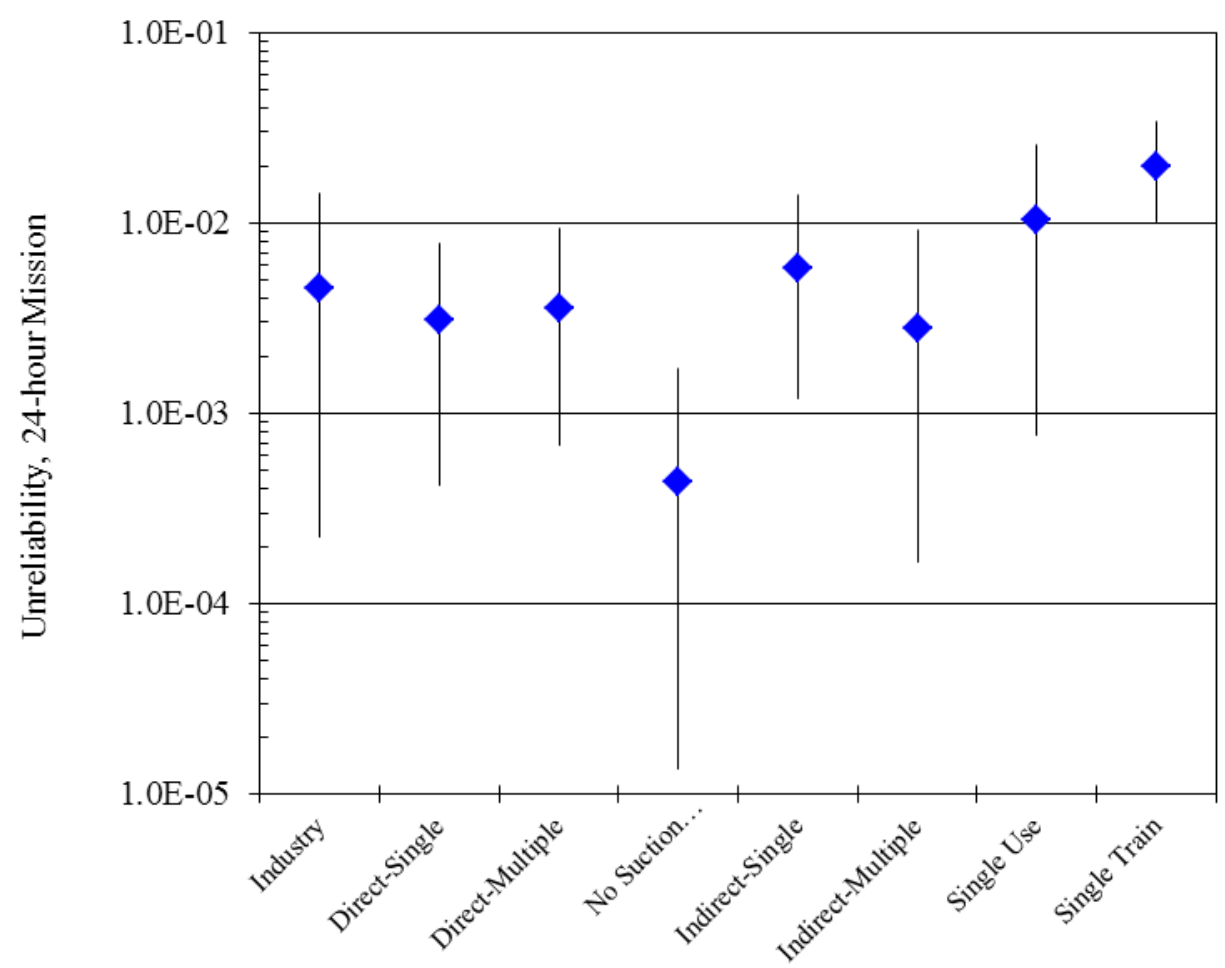

Figure 4. RHR shutdown cooling mode 24-hour mission unreliability for class and industry-wide groupings. 


\section{INDUSTRY-WIDE TRENDS}

The yearly (FY-98 through FY-14) failure and demand or run time data were obtained from ICES for the RHR system. RHR train maintenance unavailability data for trending are from the same time period, as reported in the ROP and ICES. The component basic event uncertainty was calculated for the RHR system components using the trending methods described in Section 1 and 2 of the Overview and Reference document. These data were loaded into the RHR system fault tree in each SPAR model (see Table 3).

The trend charts show the results of varying component reliability data over time and updating generic, relatively flat prior distributions using data for each year. In addition, the calculated industrywide system reliability from this update is shown. Section 4 of the Overview and Reference link on the System Studies main web page provides more detailed discussion of the trending methods. In the lower left-hand corner of the trend figures, the regression method is reported.

\subsection{Low-Pressure Injection Mode}

The components that were varied in the RHR (injection mode) model are

- RHR motor-driven pump start, run, and test and maintenance

- $\quad$ RHR heat exchanger heat transfer and test and maintenance

- Suction and Injection valves fail-to-open or close.

Figure 5 shows the trend in the RHR (injection mode) start-only model unreliability. Table 7 shows the data points for Figure 5. There is no statistically significant trend within the industry-wide estimates of RHR (injection mode) system start-only mission on a per fiscal year. Figure 6 shows the trend in the 8 -hour mission unreliability. No statistically significant trend within the industry-wide estimate of RHR (injection mode) system unreliability (8-hour mission) on a per fiscal year basis was identified. Table 8 shows the data points for Figure 6. 


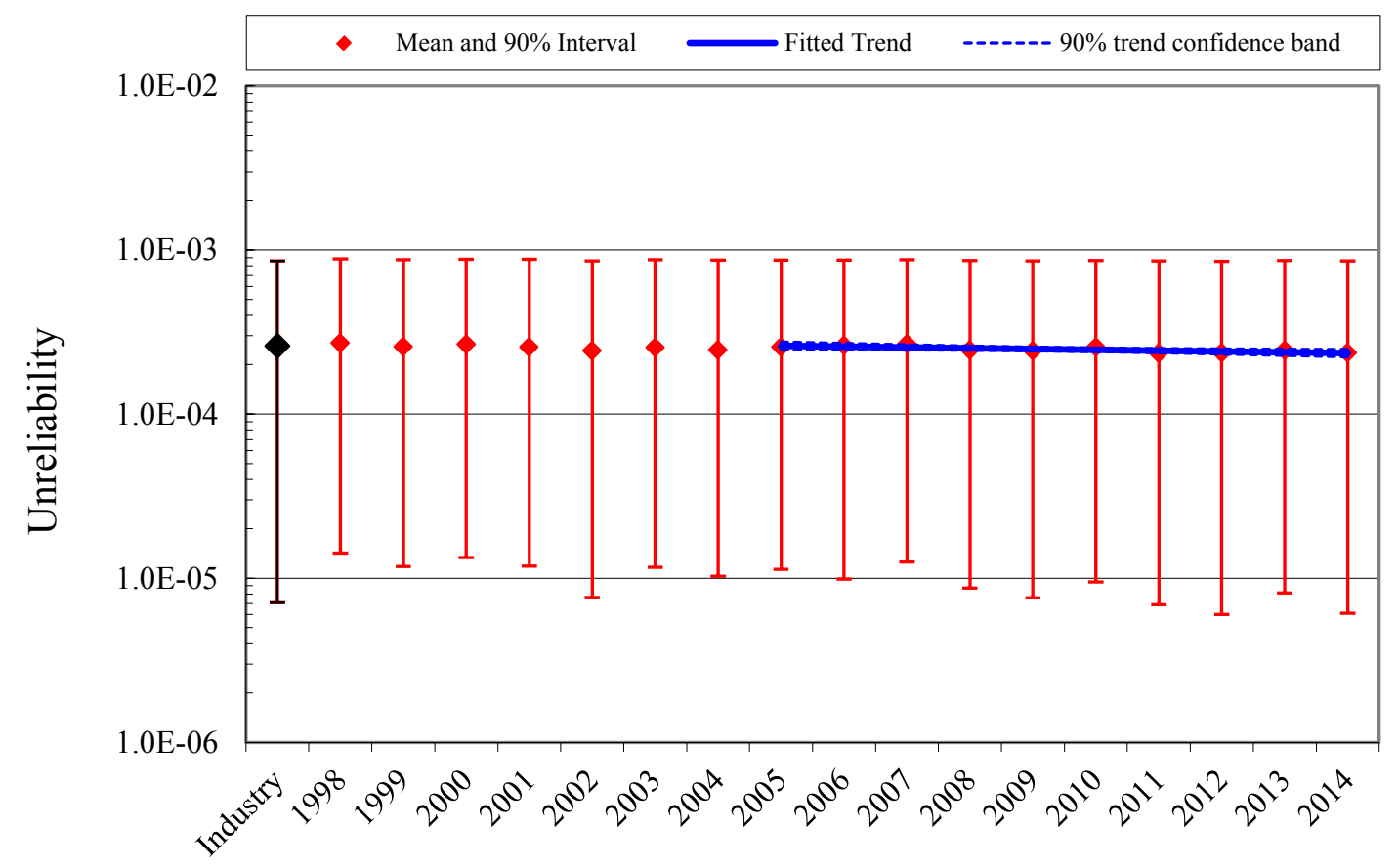

Logit model, p-value $=0.0097 \quad$ Fiscal Year Industry RHR Start-Only 1-21-2016

Figure 5. Trend of RHR (injection mode) system unreliability (start-only model), as a function of fiscal year.

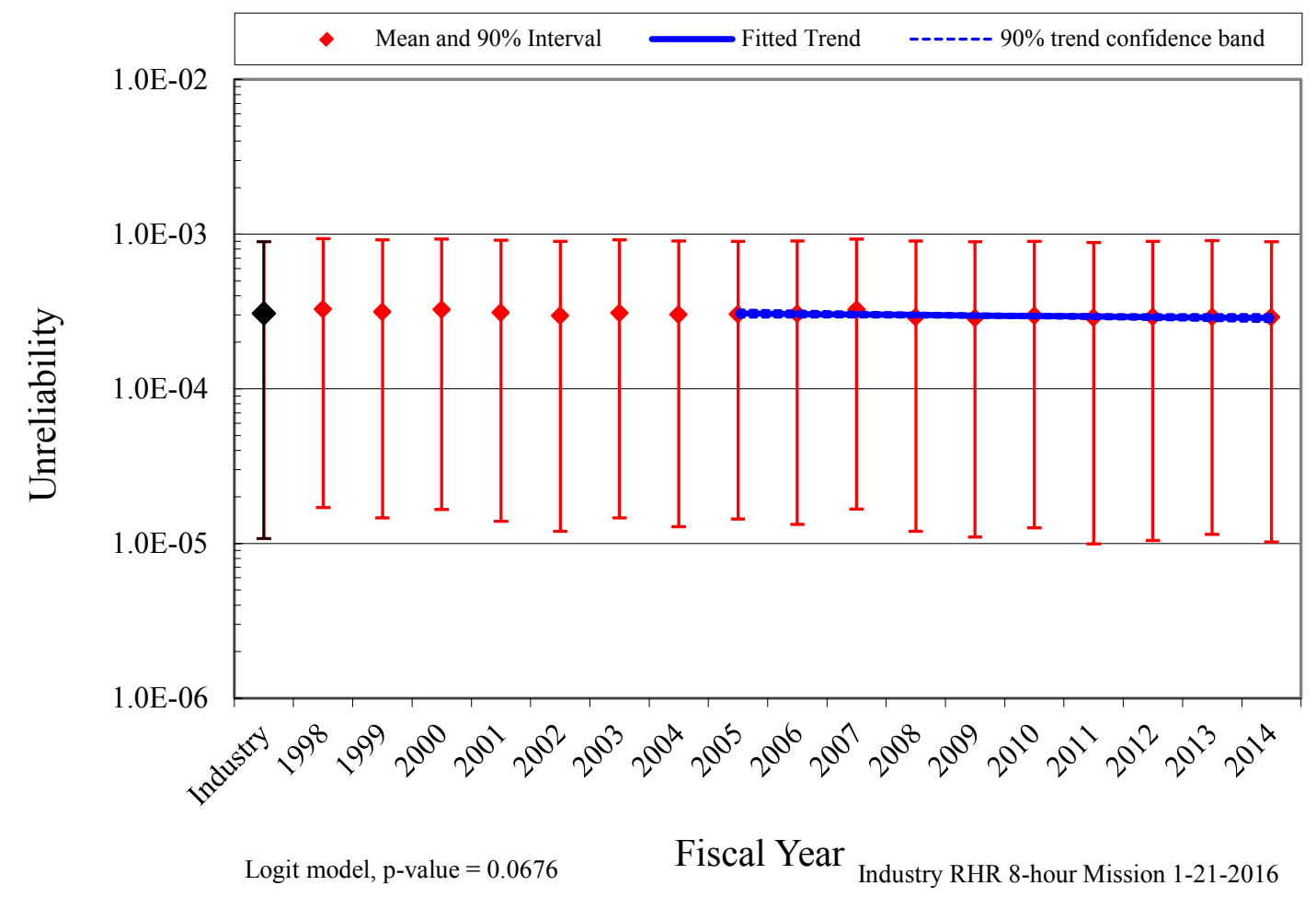

Figure 6. Trend of RHR (injection mode) system unreliability (8-hour model), as a function of fiscal year. 


\subsection{Shutdown Cooling Mode}

The components that were varied in the shutdown-cooling mode of the RHR model are:

- $\quad$ RHR motor-driven pump start, run, and test and maintenance.

- RHR heat exchanger heat transfer and test and maintenance.

- Suction and Injection valves fail-to-open or close.

Figure 7 shows the trend in the shutdown-cooling mode RHR start-only model unreliability. Table 9 shows the data points for Figure 7. No statistically significant trends within the industry-wide estimates of the shutdown-cooling mode RHR system start-only mission on a per fiscal year basis were identified. Figure 8 shows the trend in the 24-hour mission unreliability. No statistically significant trend within the industry-wide estimates of RHR system unreliability (24-hour mission) on a per fiscal year basis was identified. Table 10 shows the data points for Figure 8.

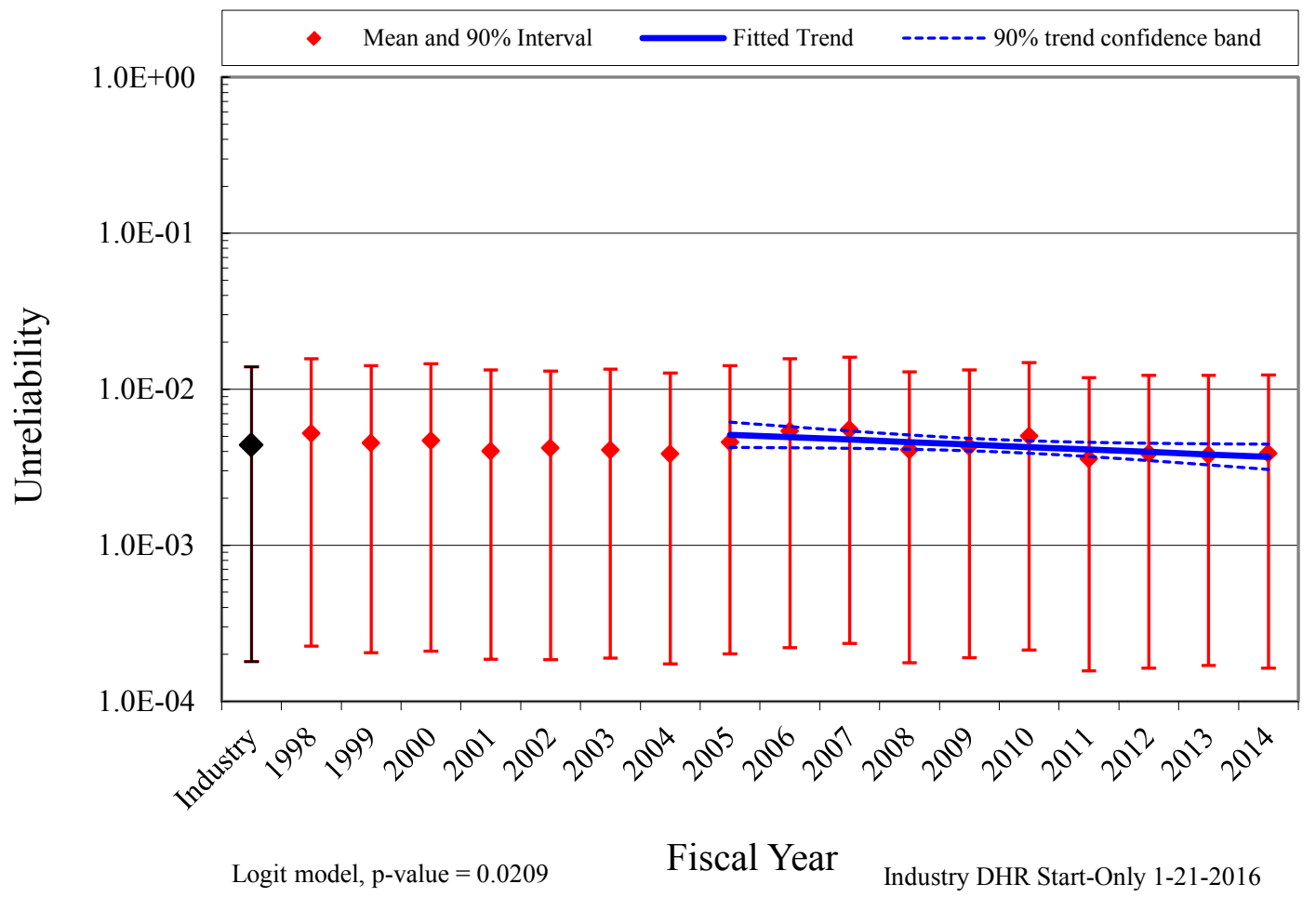

Figure 7. Trend of RHR shutdown cooling mode system unreliability (start-only model), as a function of fiscal year. 


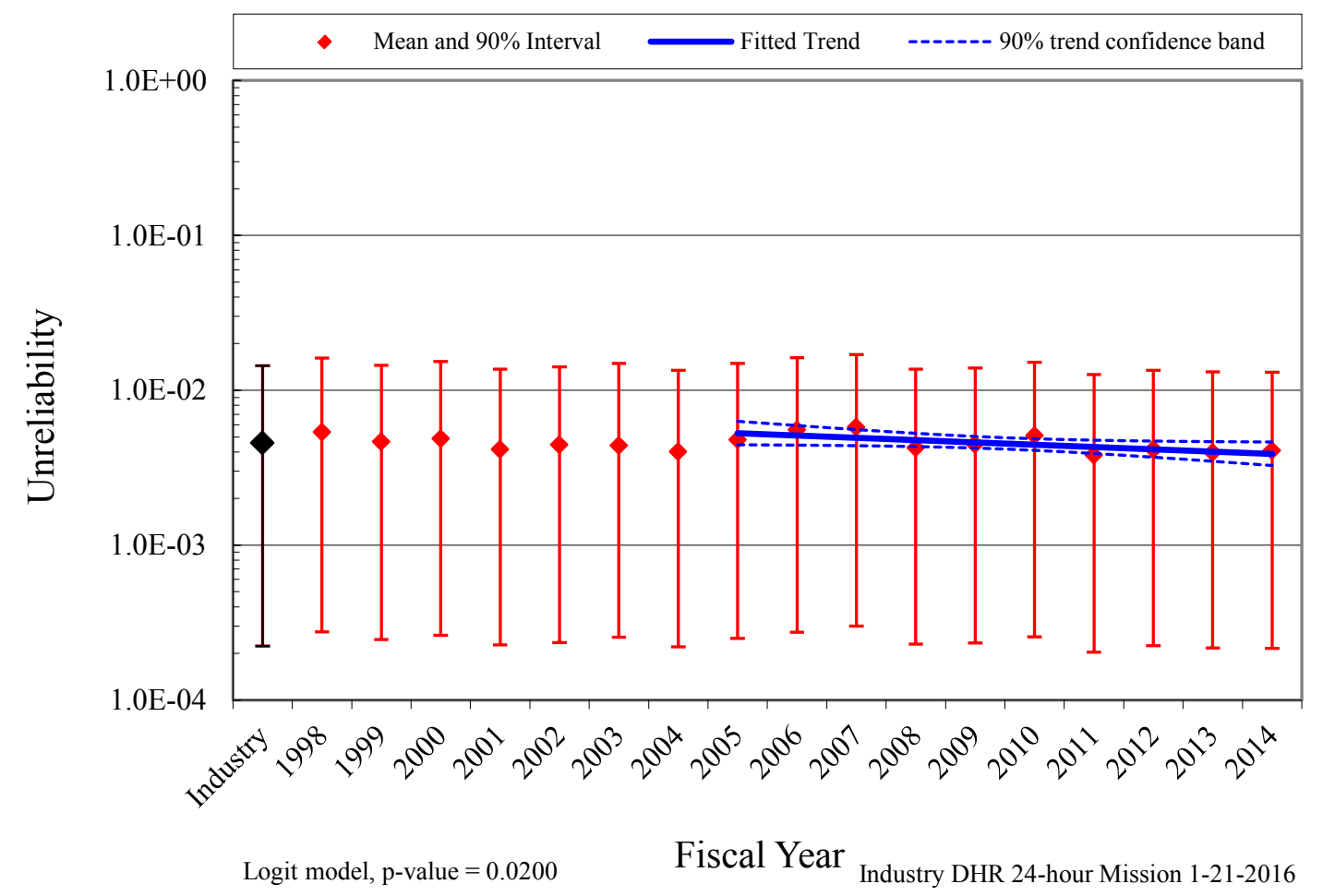

Figure 8. Trend of RHR shutdown cooling mode system unreliability (24-hour model), as a function of fiscal year. 


\section{BASIC EVENT GROUP IMPORTANCES}

The RHR basic event group Fussell-Vesely importances were calculated for each plant using the industry-wide data (1998-2010). These basic event group importances were then averaged across all plants to represent an industry-wide basic event group importance. Table 6 shows the SPAR model RHR importance groups and their descriptions.

Table 6. RHR model basic event importance group descriptions.

\begin{tabular}{|c|c|}
\hline Group & Description \\
\hline AC Power & The ac buses and circuit breakers that supply power to the RHR pumps. \\
\hline CCW & $\begin{array}{l}\text { Closed cooling water system. An intermediate cooling system that transfers the } \\
\text { heat to the ultimate heat sink. }\end{array}$ \\
\hline DC Power & The batteries and battery chargers that supply power to the pump control circuitry. \\
\hline EPS & RHR dependency on the emergency power system. \\
\hline HA Start RHR & Human action to start the pumps and re-align any valves. \\
\hline Heat Sink & $\begin{array}{l}\text { The pumps, valves, strainers and other equipment associated with the ultimate } \\
\text { heat sink. }\end{array}$ \\
\hline Human Action & Other human actions for recovery of equipment. \\
\hline Injection & The flow path equipment, to direct the shutdown cooling water to the RCS loop. \\
\hline Instrument Air & Instrument air support to the RHR model. \\
\hline Min Flow & $\begin{array}{l}\text { The minimum flow valves around the RHR heat exchangers. These are used to } \\
\text { control the cooldown rate. }\end{array}$ \\
\hline Pump Cooling & Cooling provided to the shutdown cooling pumps. \\
\hline RHR HTX & $\begin{array}{l}\text { The first heat exchanger in the system to transfer heat from the RCS to the next } \\
\text { level of heat removal. }\end{array}$ \\
\hline RHR MDP & $\begin{array}{l}\text { The motor-driven pumps that provide the recirculation flow from the RCS loop } \\
\text { back to the RCS. }\end{array}$ \\
\hline Room Cooling & Cooling provided to the room the shutdown cooling pumps are located in. \\
\hline Special & $\begin{array}{l}\text { Various events used in the models that are not directly associated with the RHR } \\
\text { system. }\end{array}$ \\
\hline Suction & $\begin{array}{l}\text { Valves in the suction section of the shutdown cooling system. These valves are } \\
\text { required to change position to redirect the suction to the RCS loop. }\end{array}$ \\
\hline
\end{tabular}

\subsection{Low-Pressure Injection Mode}

The industry-wide RHR start-only and 8-hour basic event group importances for low-pressureinjection mode are shown in Figure 9. In both cases, the leading contributors to RHR LPI system unreliability are the RHR motor-driven pumps followed by the injection flow path. For more discussion on the RHR motor-driven pumps and the RHR motor-operated and air-operated valves (MOVs and AOVs), see the component reliability studies at NRC Reactor Operational Experience Results and Databases.

The basic event group importances were also averaged across plants of the same RHR class to represent class basic event group importances. The RHR class-specific start-only and 8-hour basic event group importances are shown in Figure 10 to Figure 18. 


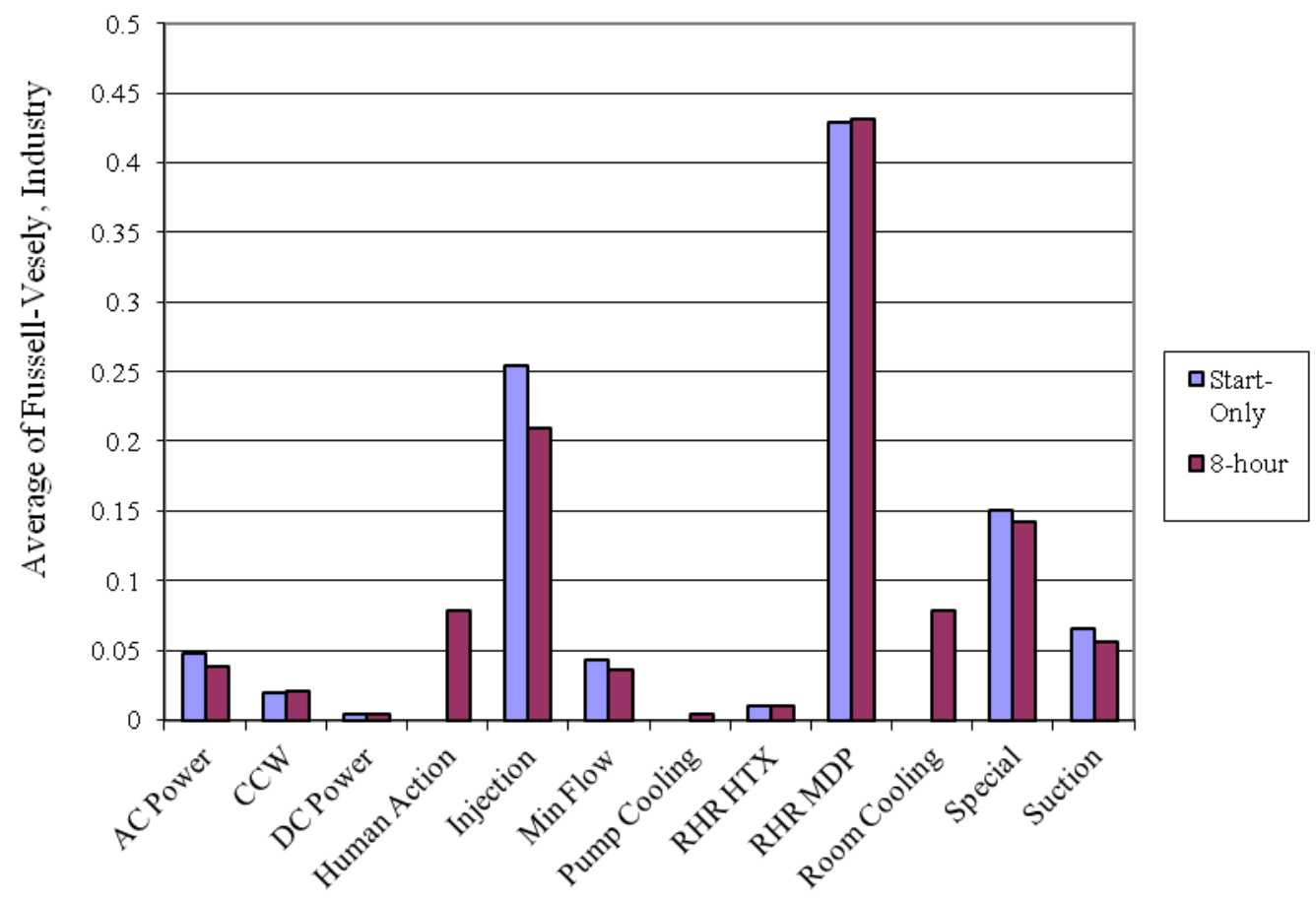

Basic Event Group

Figure 9. RHR (injection mode) industry-wide basic event group importances.

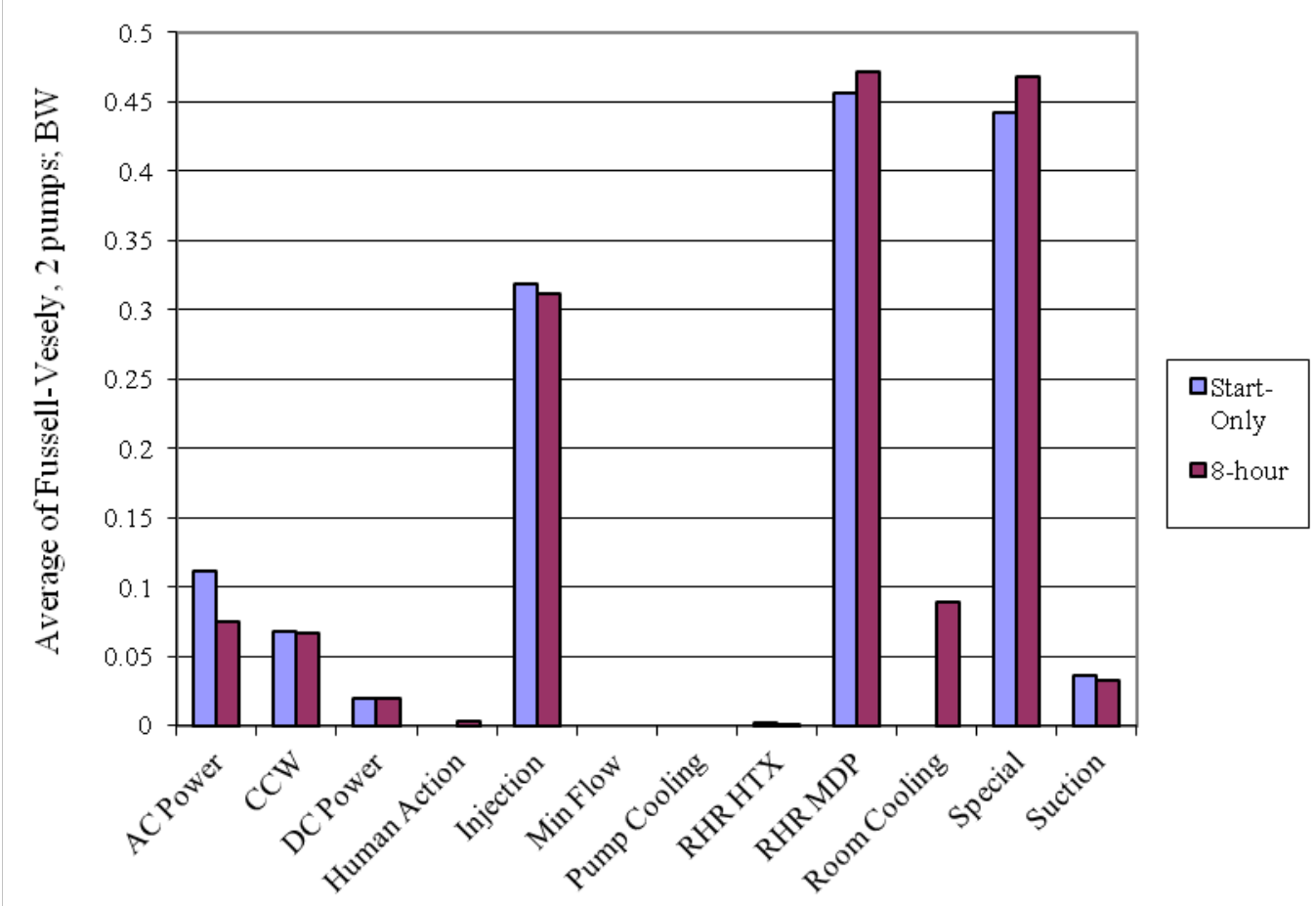

Basic Event Group

Figure 10. RHR (injection mode) two pump BW basic event group importances. 


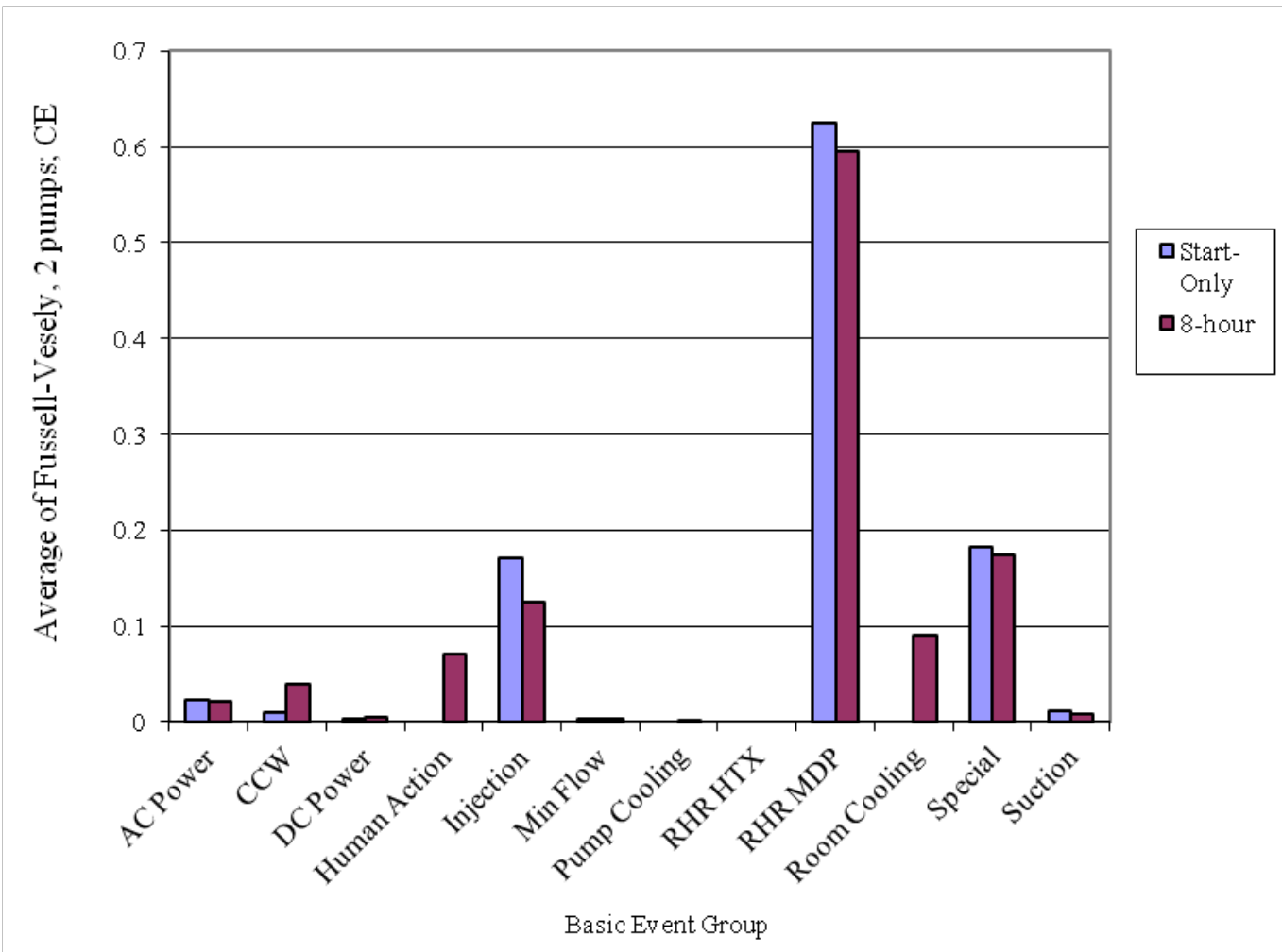

Figure 11. RHR (injection mode) two pumps CE basic event group importances.

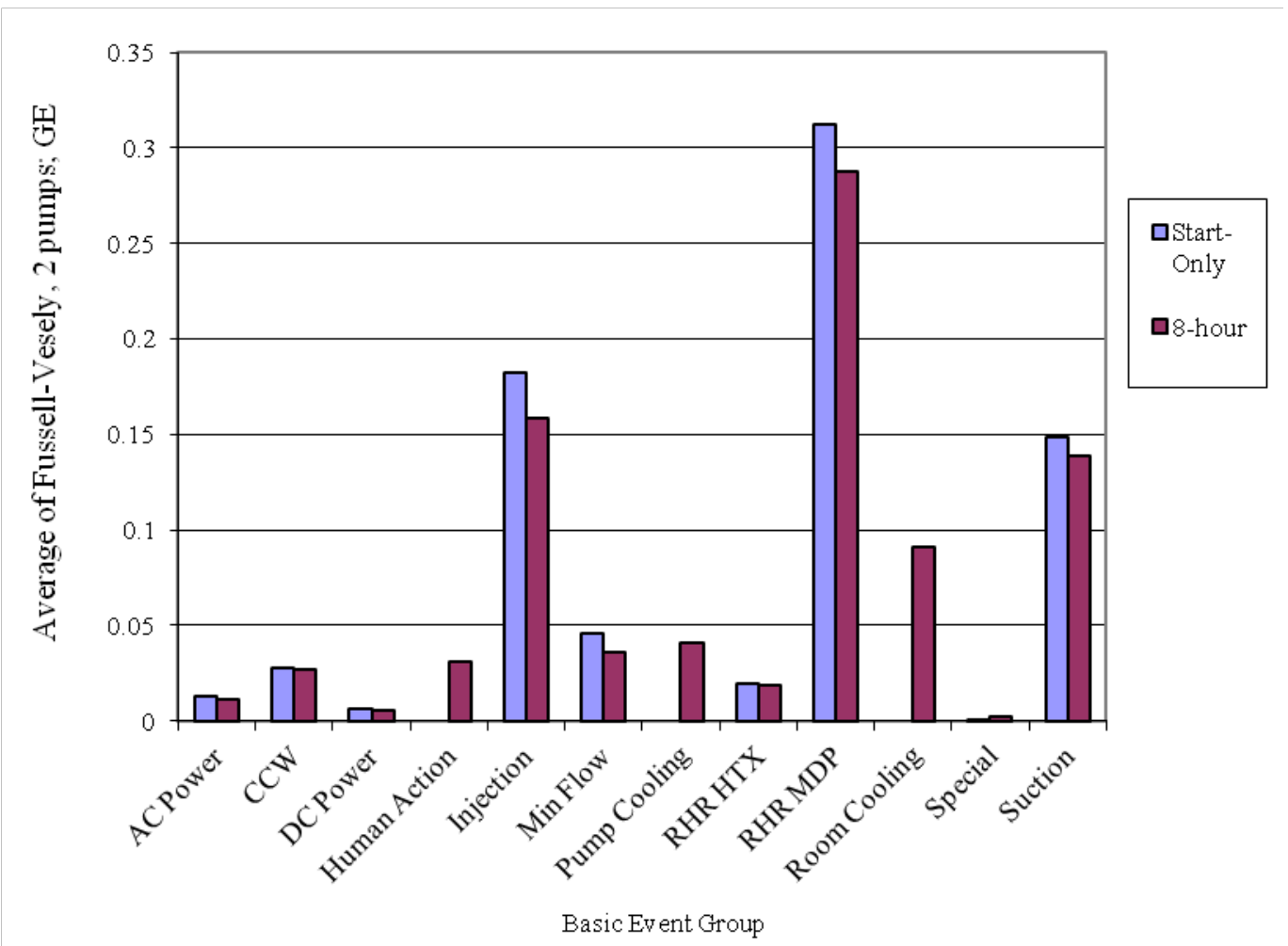

Figure 12. RHR (injection mode) two pumps GE basic event group importances. 


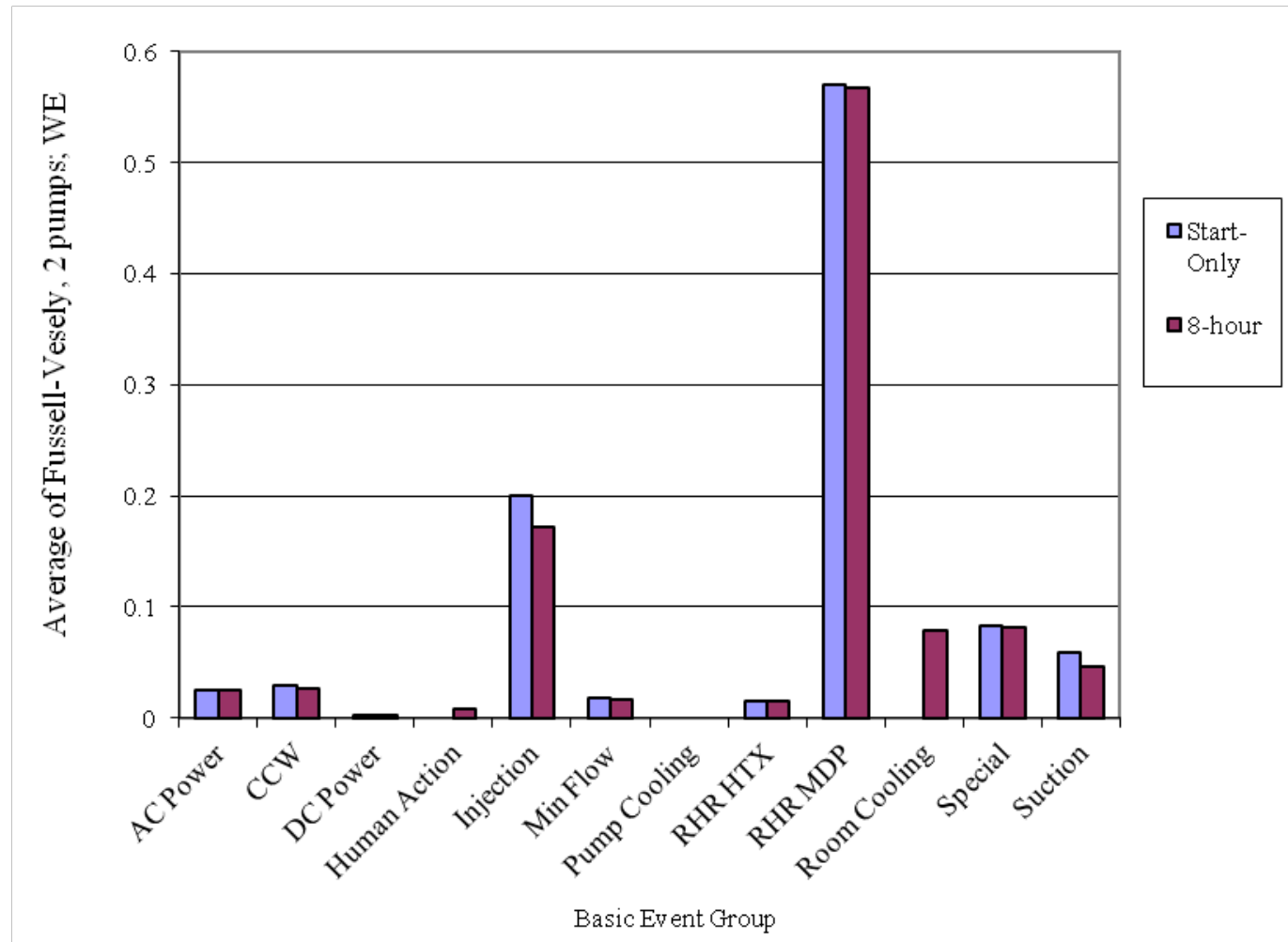

Figure 13. RHR (injection mode) two pumps WE basic event group importances.

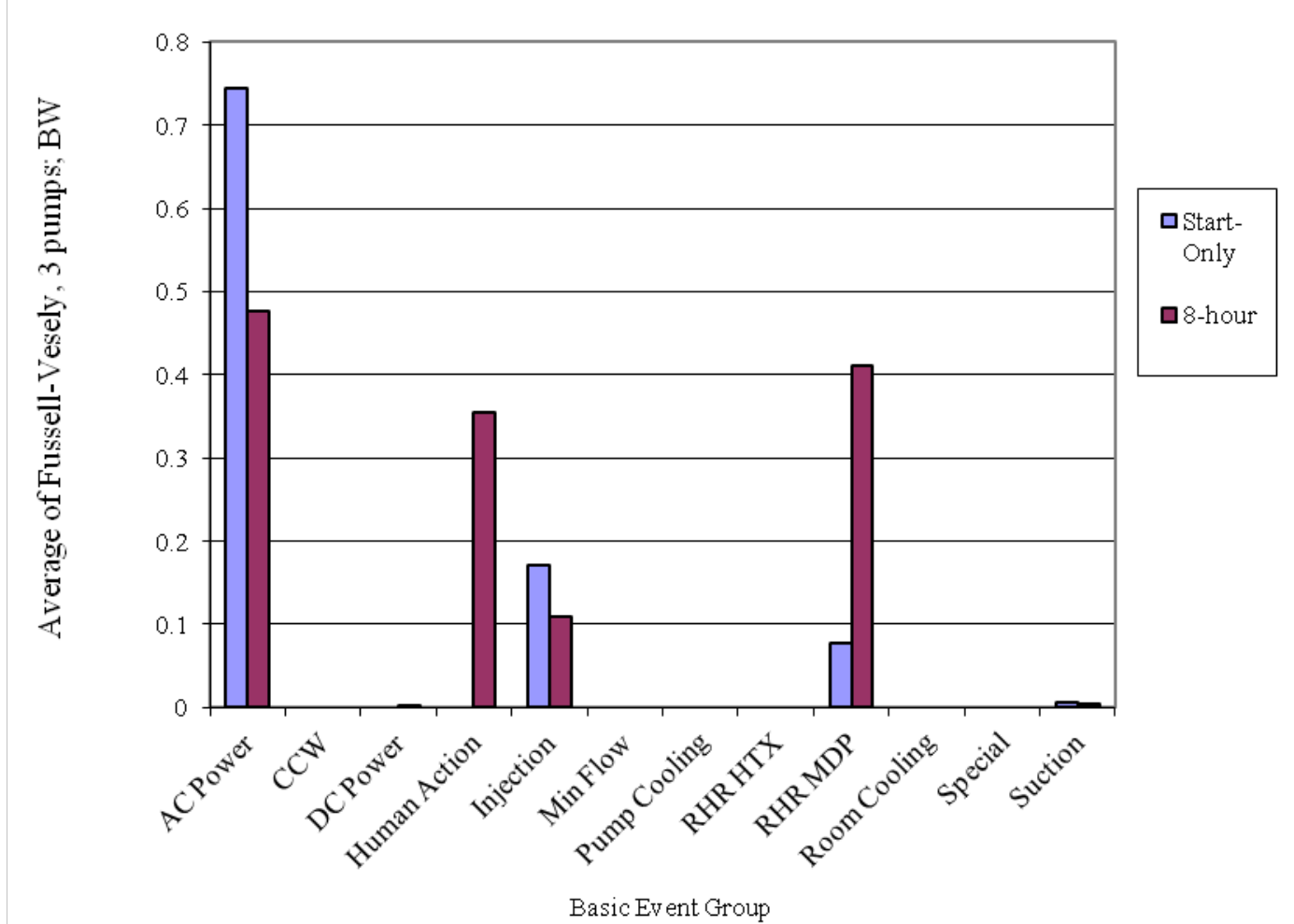

Figure 14. RHR (injection mode) three pumps BW basic event group importances. 


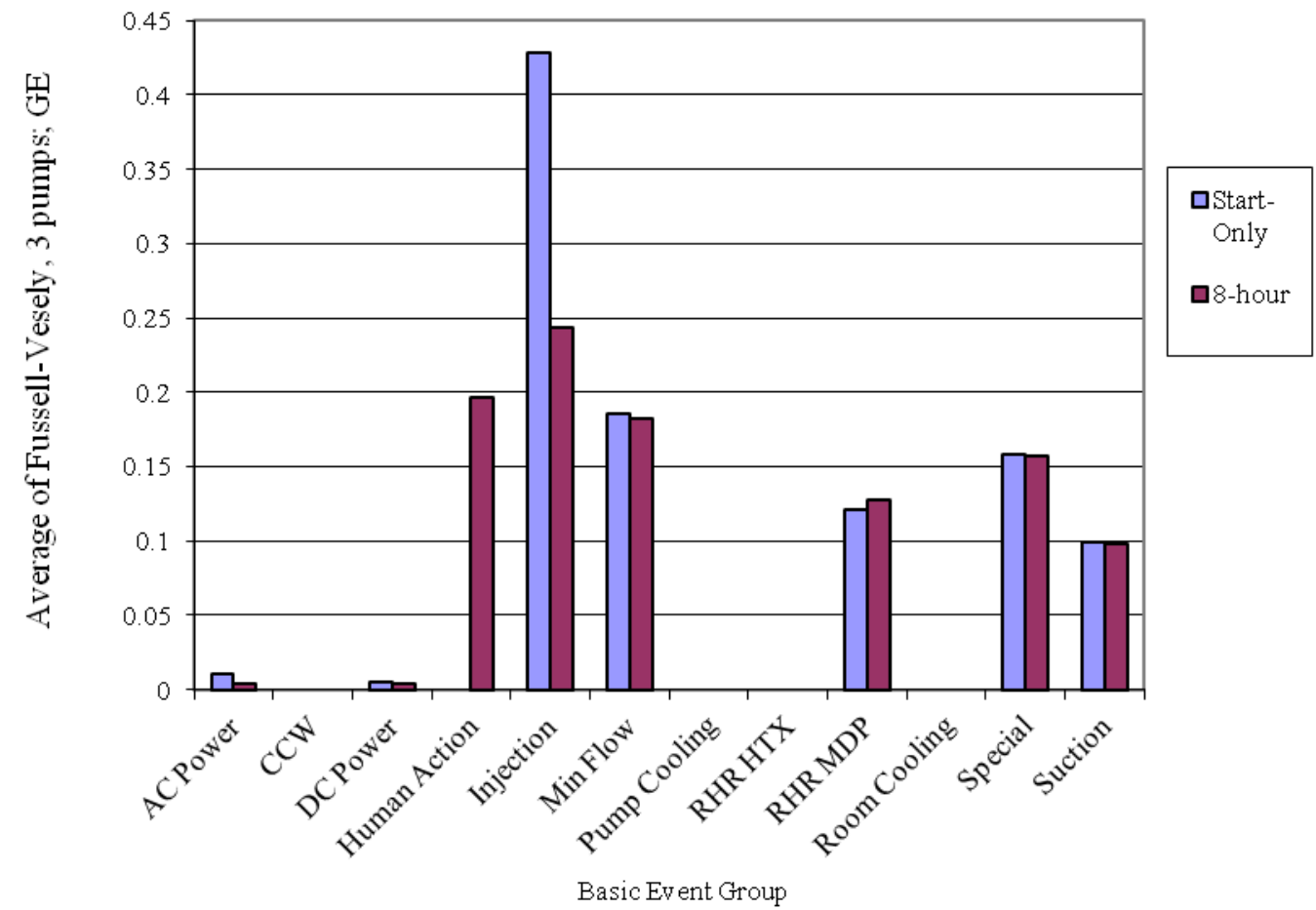

Figure 15. RHR (injection mode) three pumps GE basic event group importances.

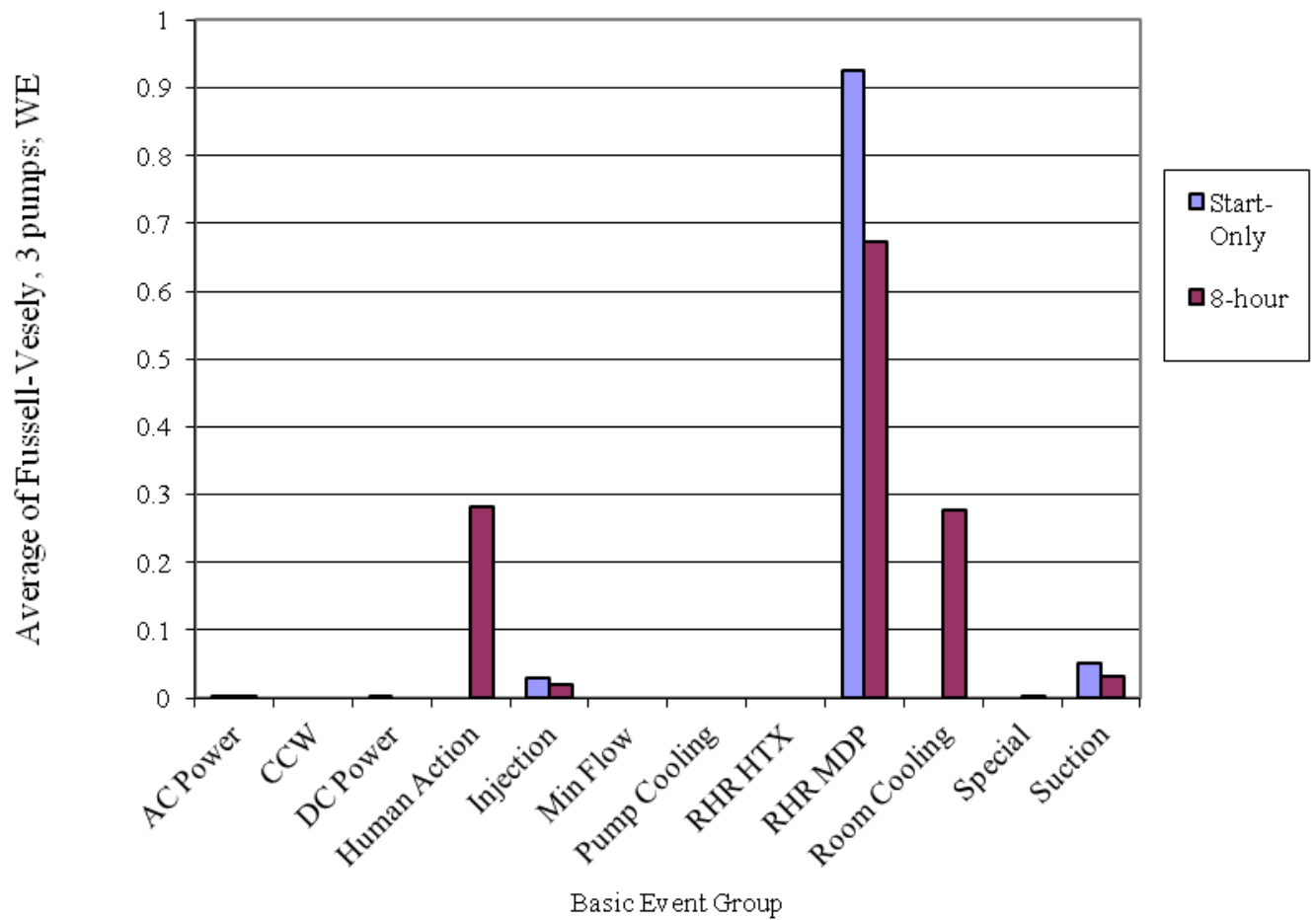

Figure 16. RHR (injection mode) three pumps WE basic event group importances. 


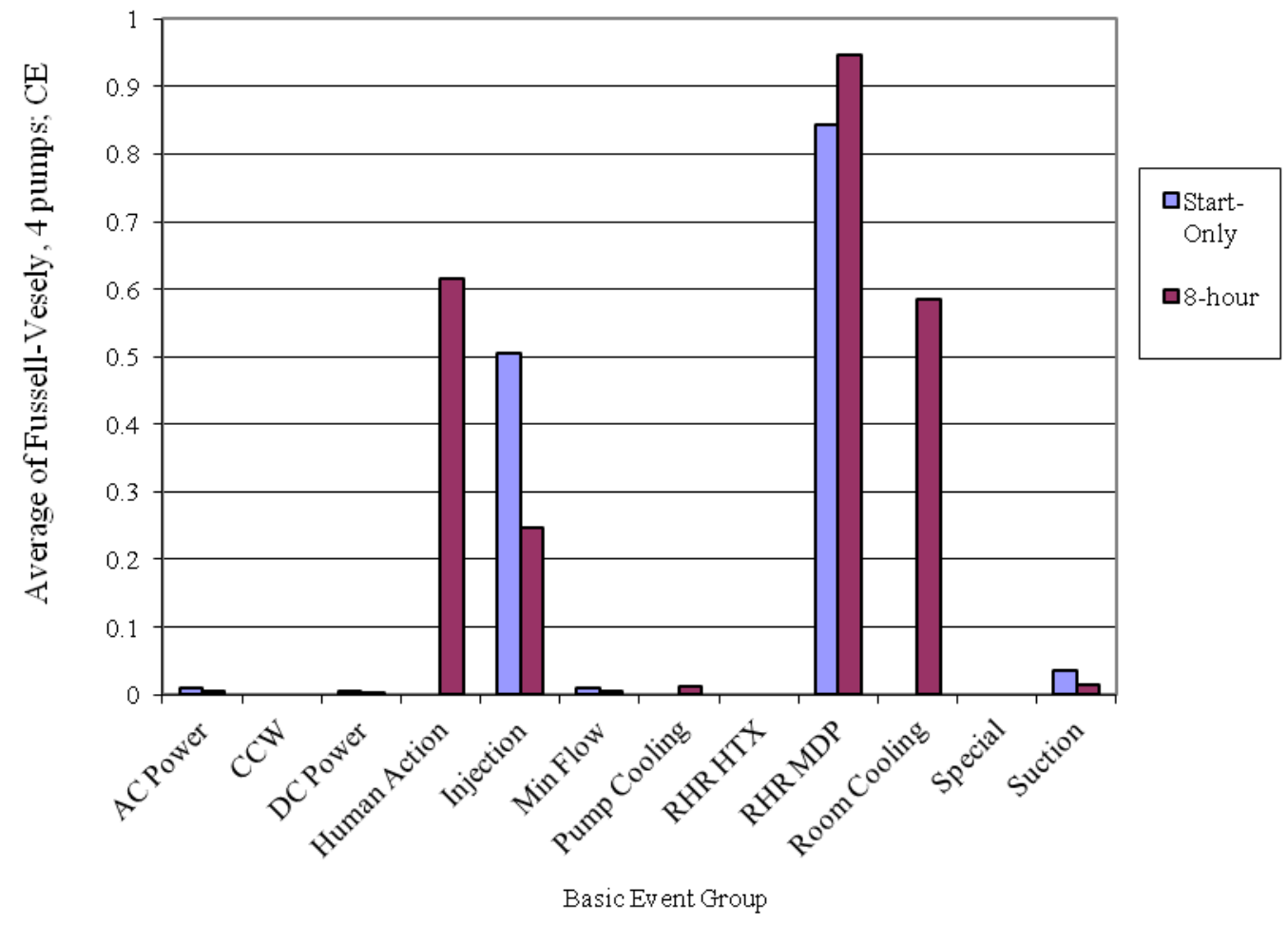

Figure 17. RHR (injection mode) four pumps CE basic event group importances.

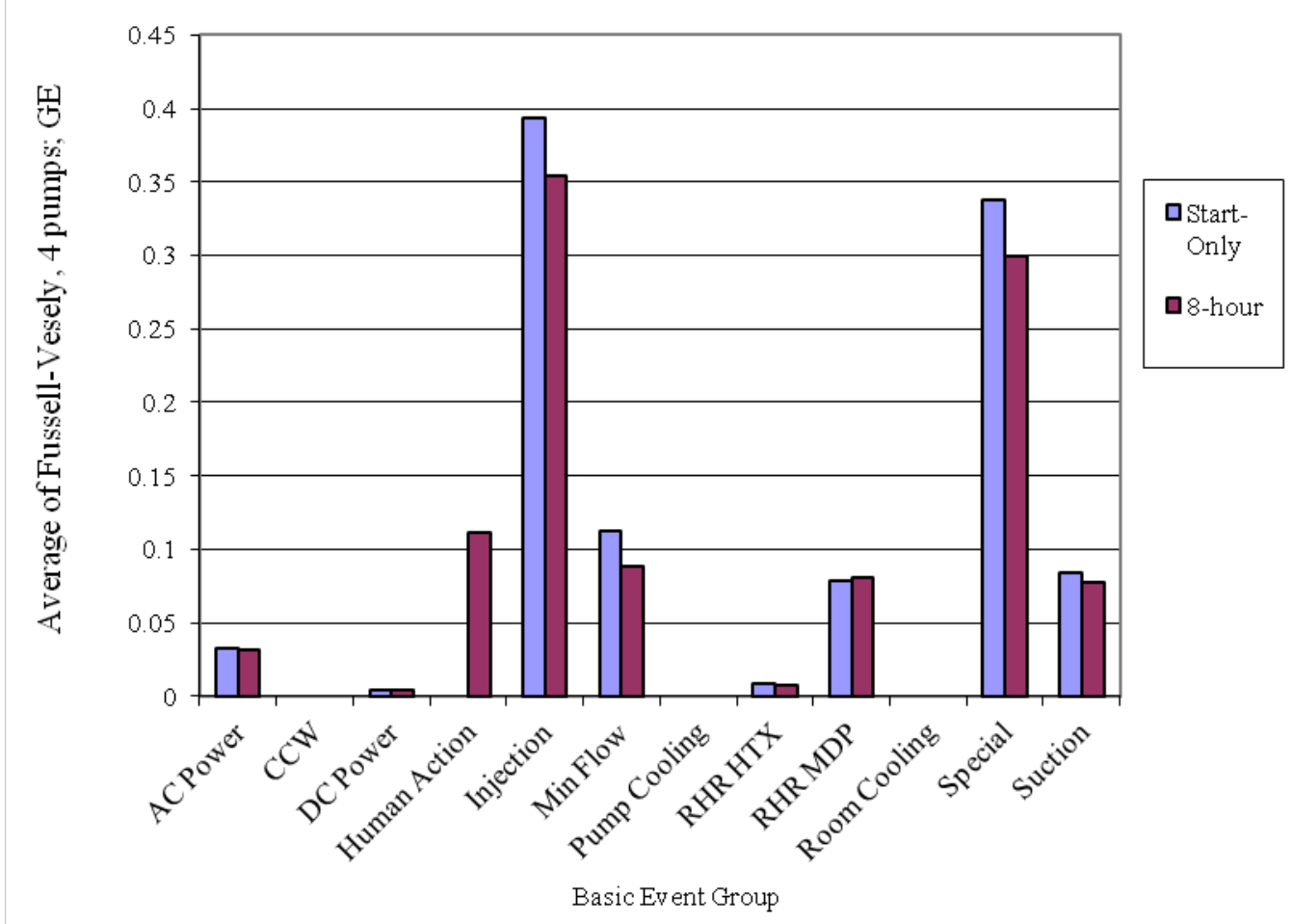

Figure 18. RHR (injection mode) four pumps GE basic event group importances. 


\subsection{Shutdown Cooling Mode}

The industry-wide RHR start-only and 24-hour basic event group importances for shutdown cooling mode are shown in Figure 19. In both cases, the leading contributor to RHR system unreliability is the realignment of the RHR suction flowpath followed by random failures of the injection flow path. For more discussion on the RHR MOVs and AOVs, see the MOV and AOV component reliability studies at NRC Reactor Operational Experience Results and Databases.

The basic event group importances were also averaged across plants of the same RHR class to represent class basic event group importances. The RHR class-specific start-only and 24-hour basic event group importances are shown in Figure 20 to Figure 26.

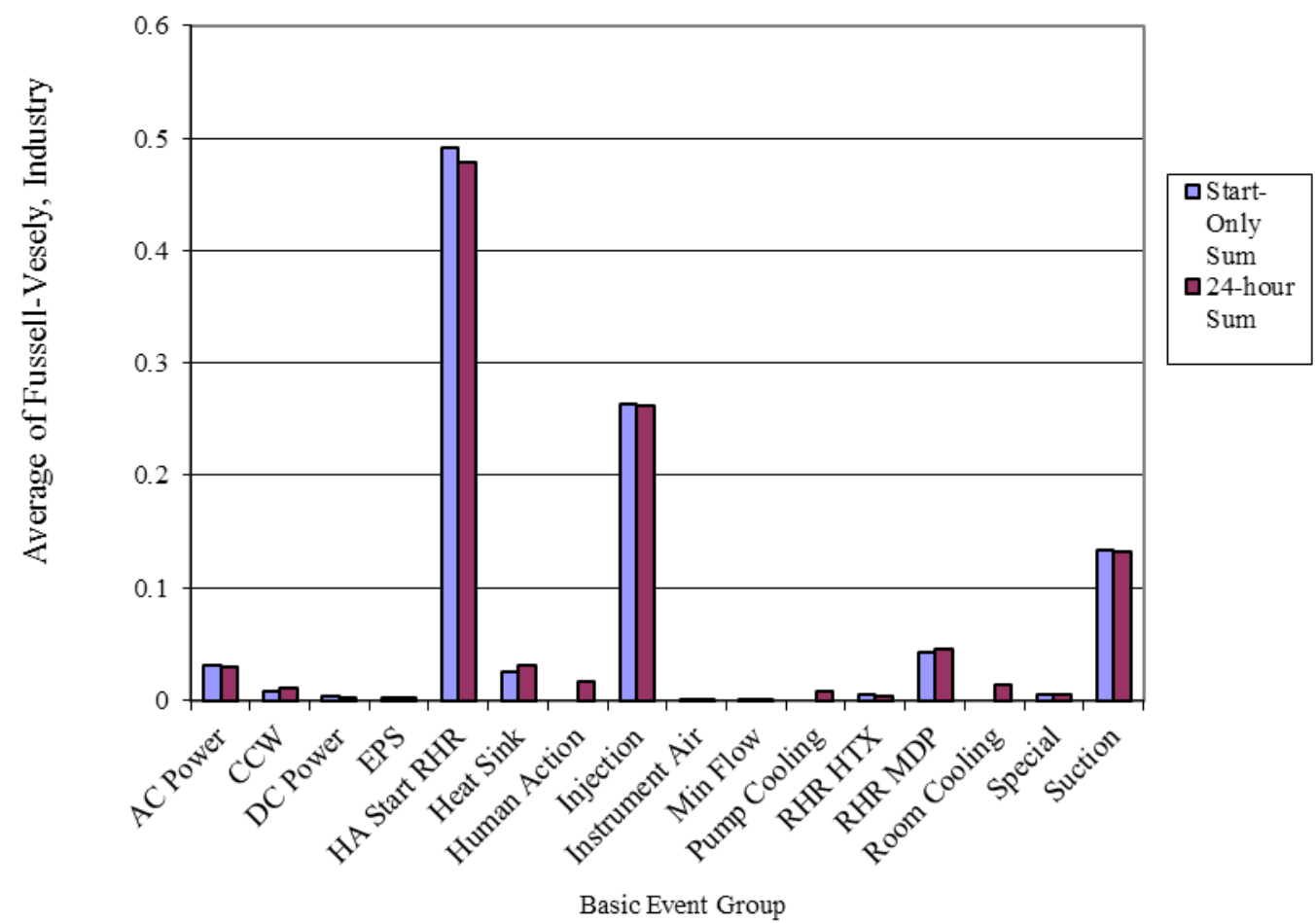

Figure 19. RHR shutdown cooling mode industry-wide basic event group importances. 


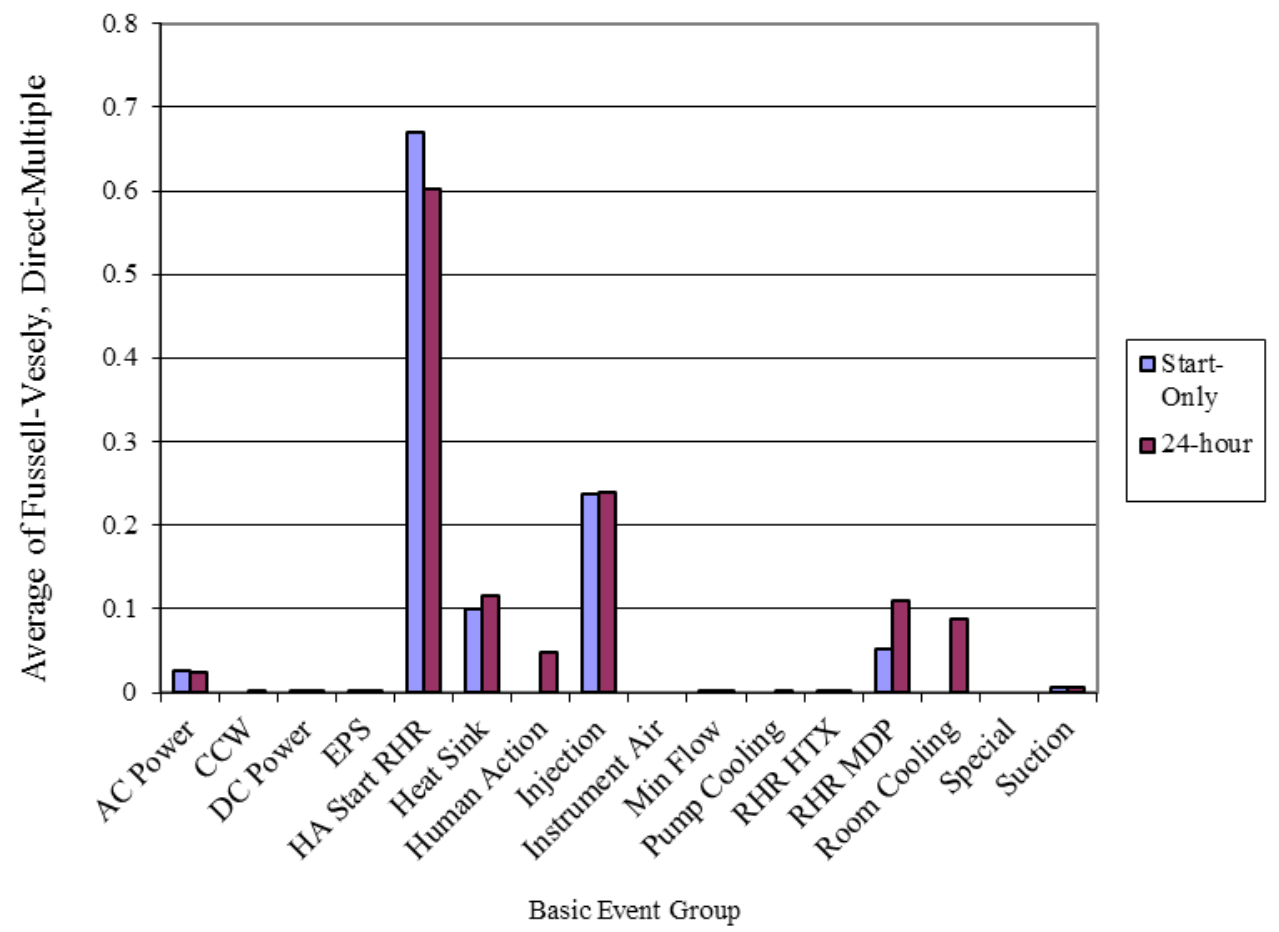

Figure 20. RHR shutdown cooling mode direct heat sink, multiple suction path basic event group importances.

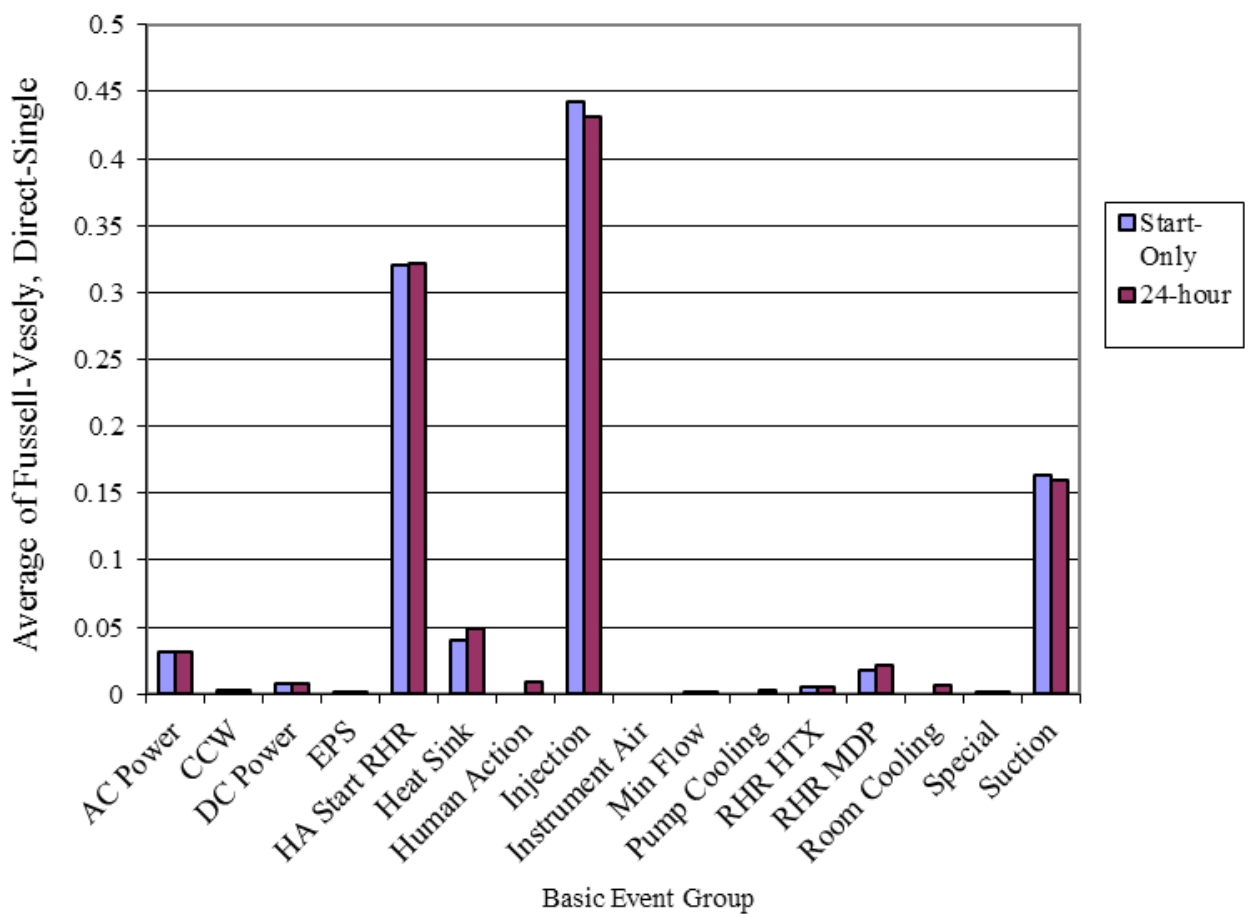

Figure 21. RHR shutdown cooling mode direct heat sink, single suction path basic event group importances. 


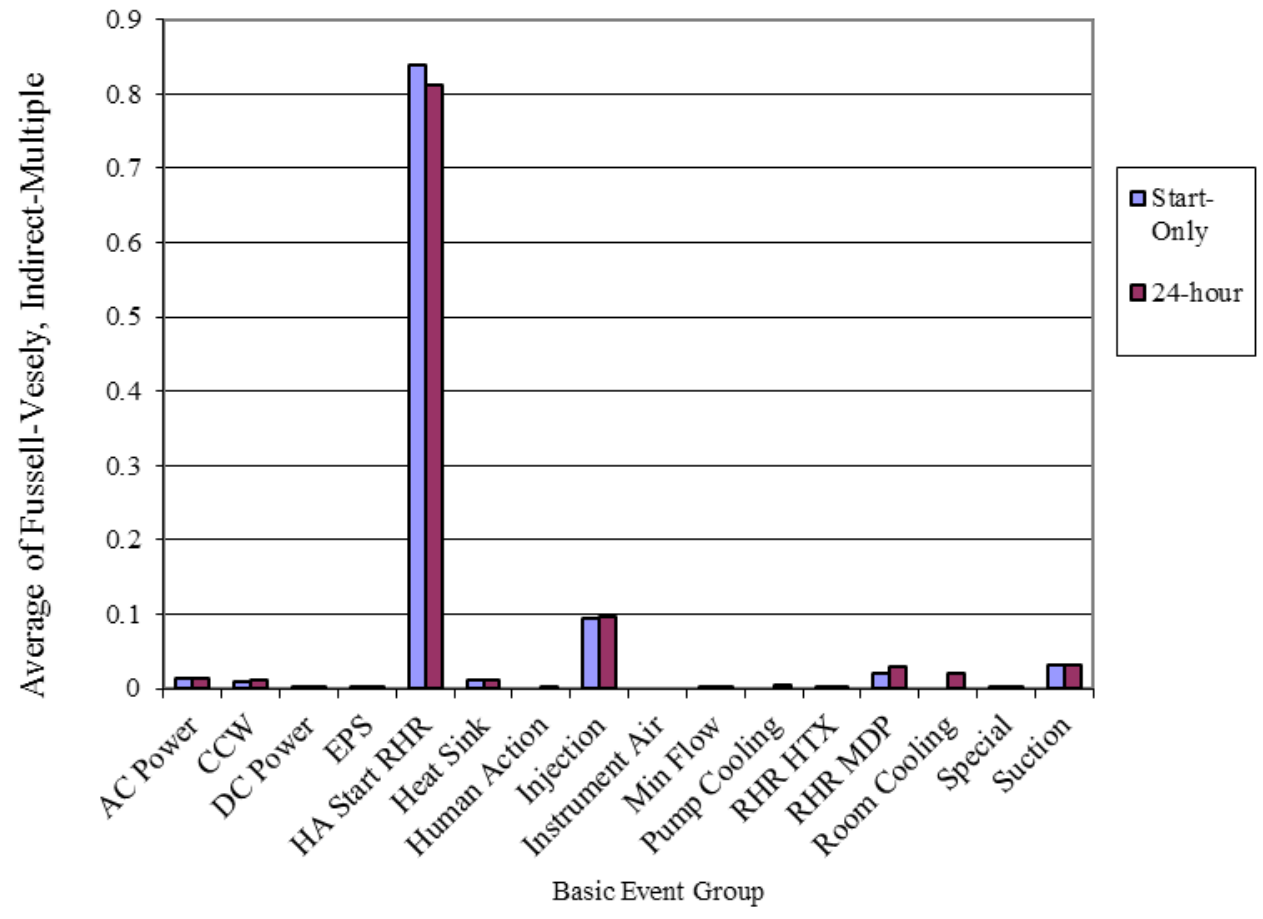

Figure 22. RHR shutdown cooling mode indirect heat sink, multiple suction paths basic event group importances.

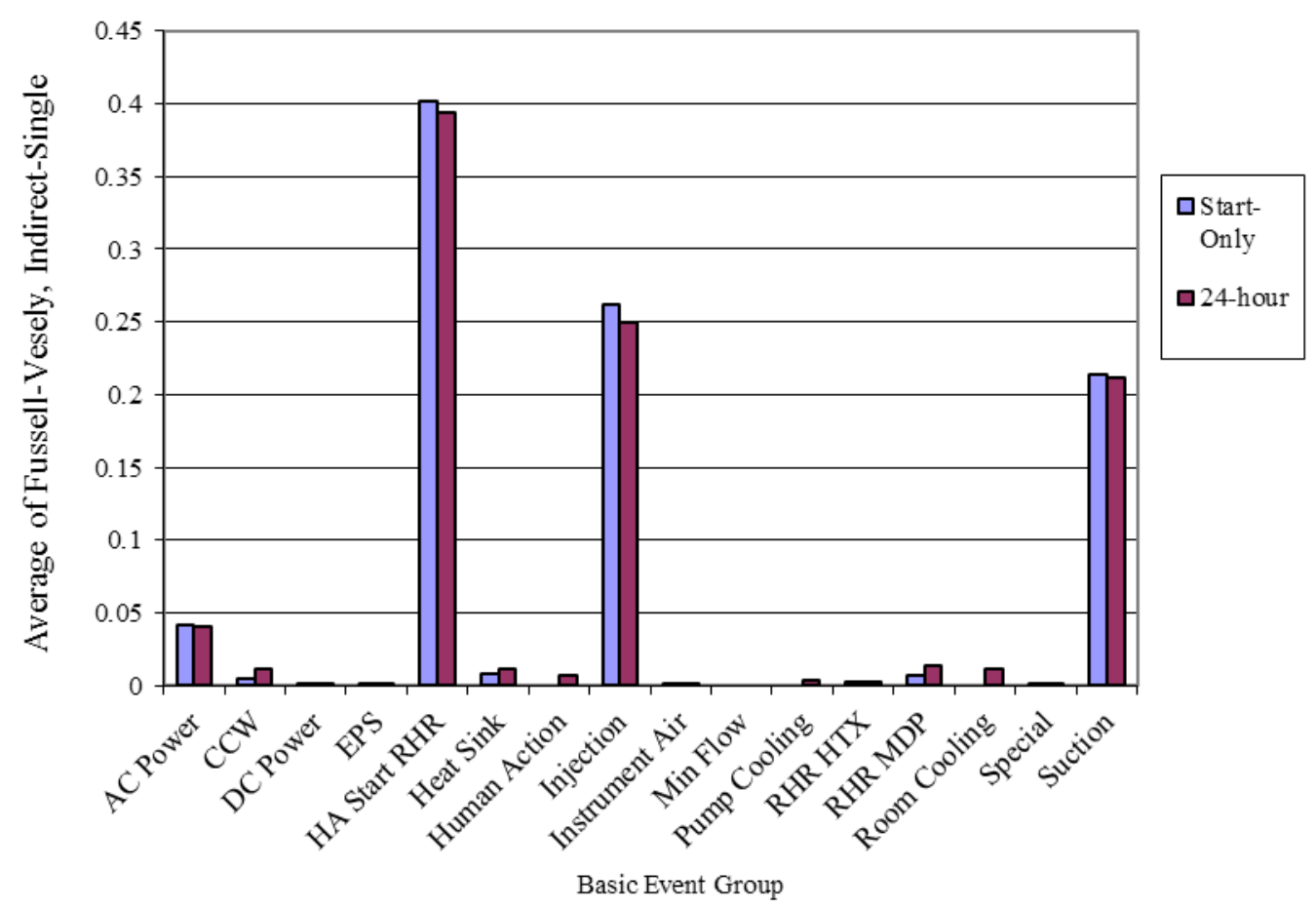

Figure 23. RHR shutdown cooling mode indirect heat sink, single suction path basic event group importances. 


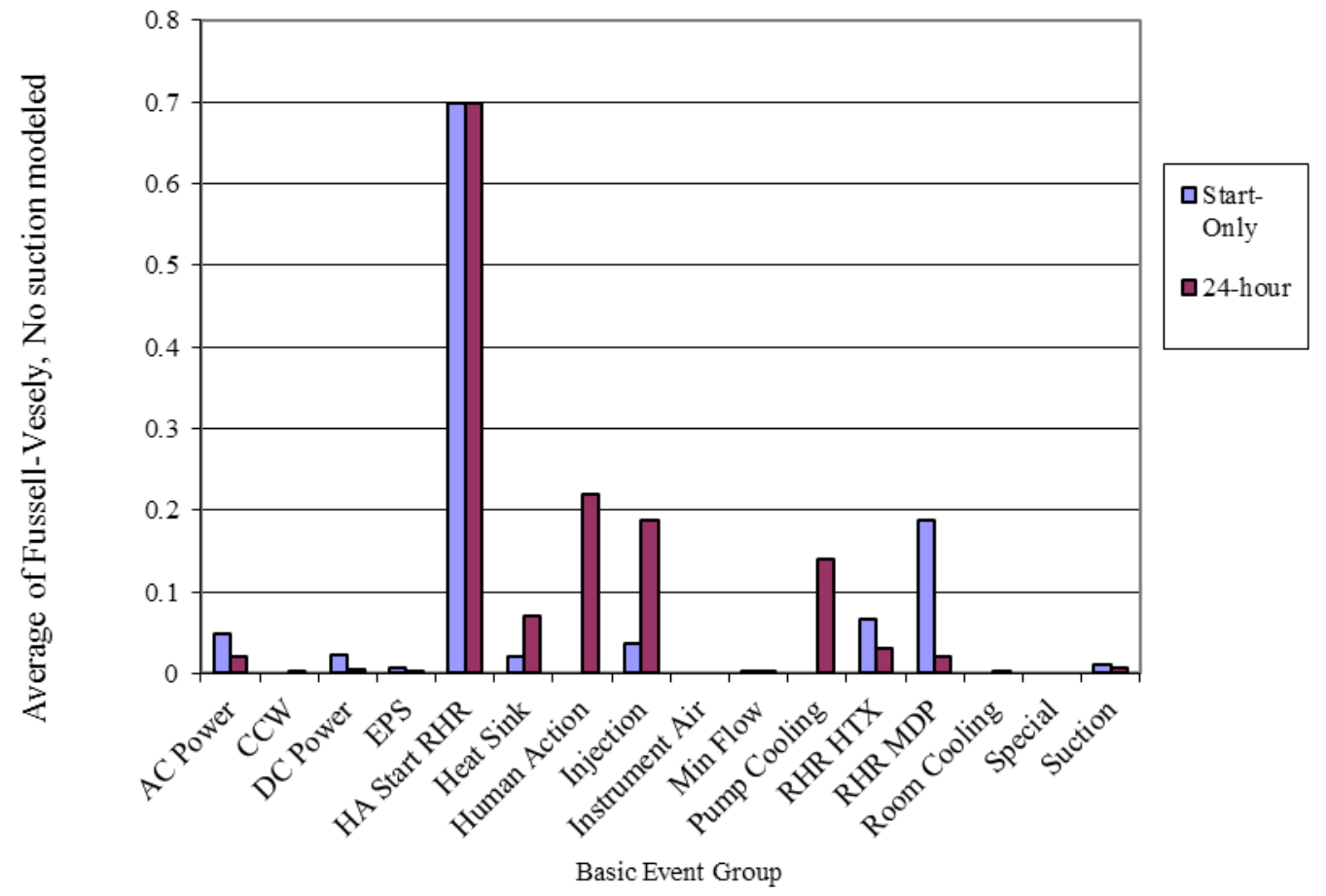

Figure 24. RHR shutdown cooling mode no suction modeled basic event group importances.

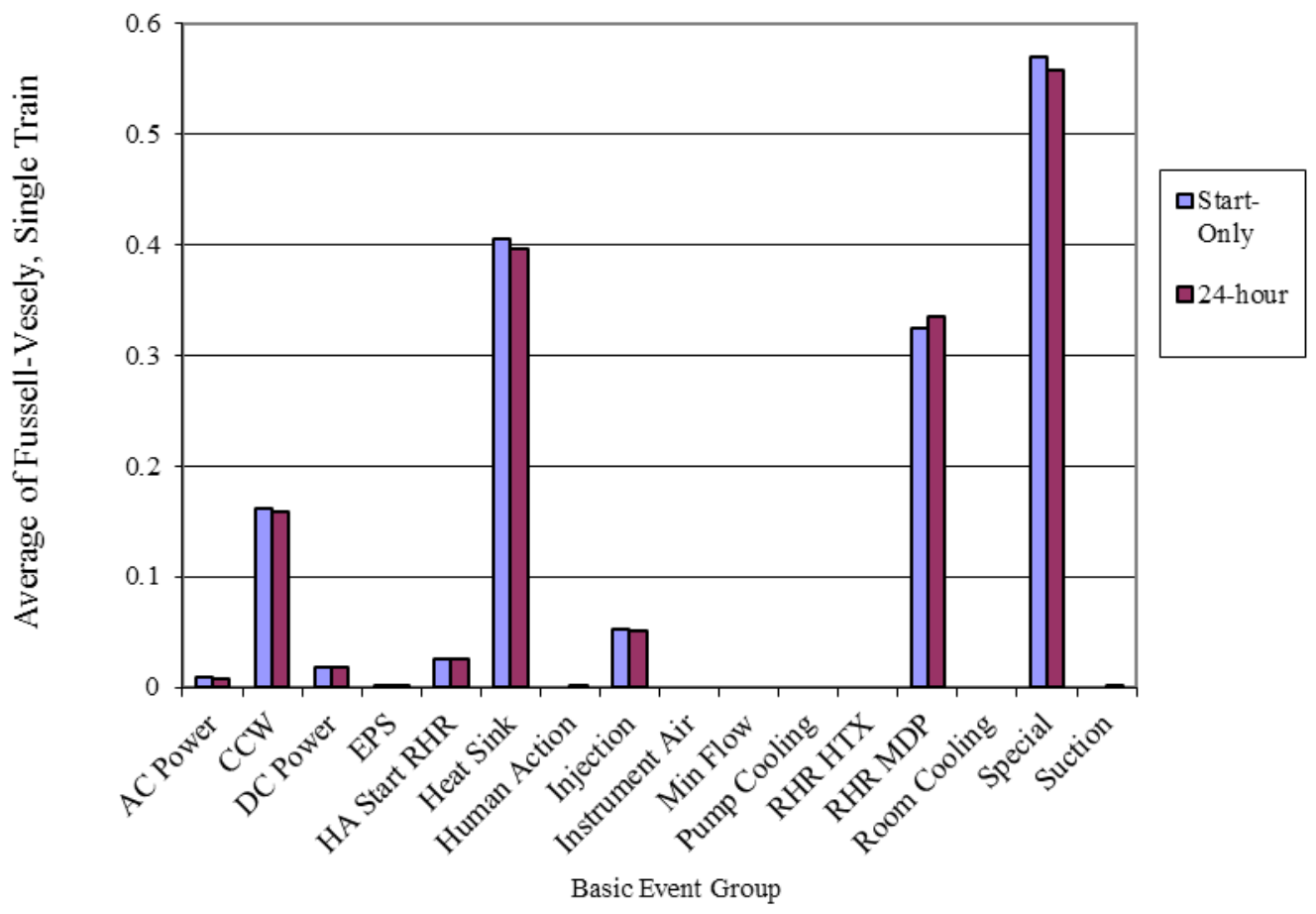

Figure 25. RHR shutdown cooling mode single train basic event group importances. 


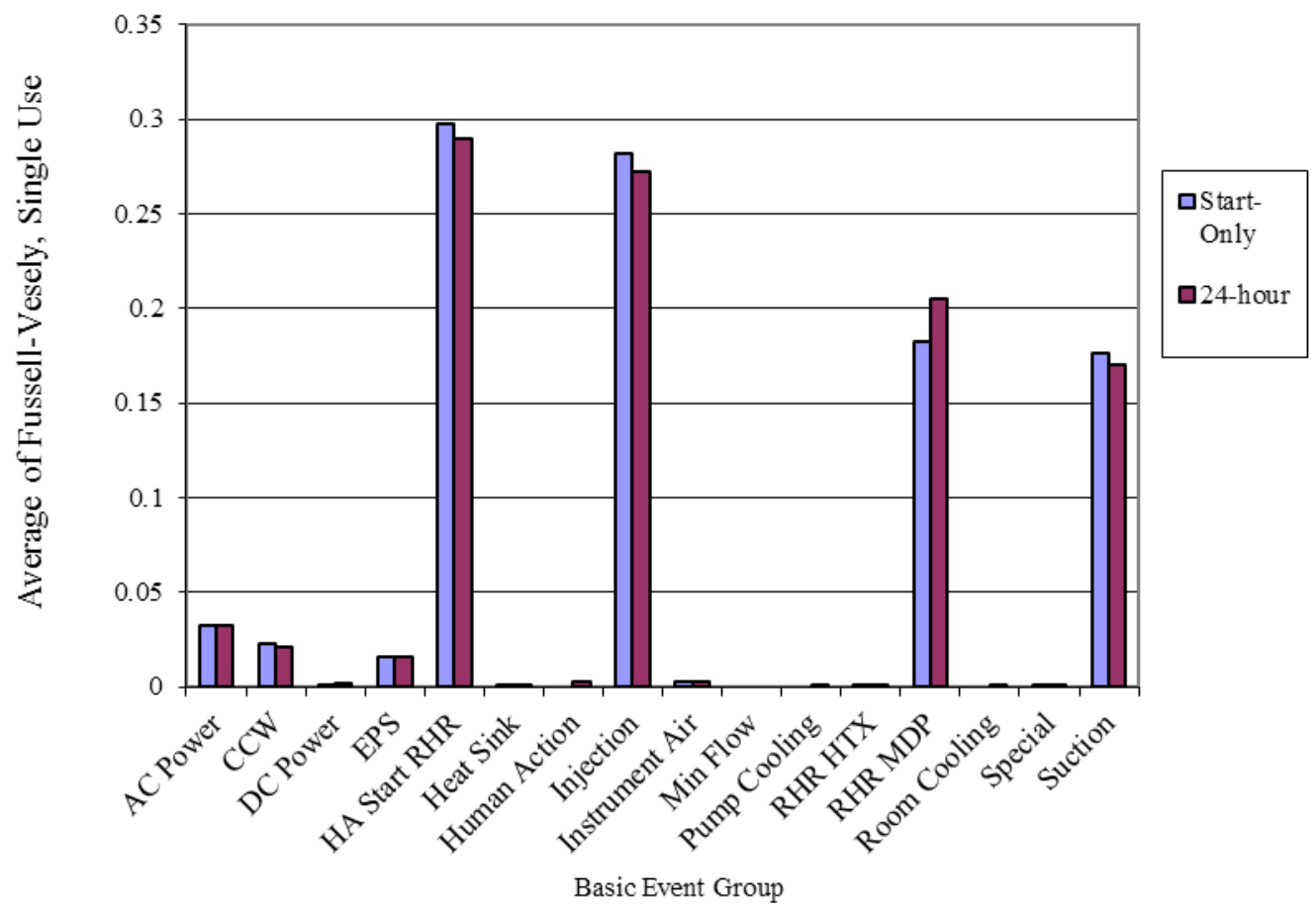

Figure 26. RHR shutdown cooling mode single use SDC system basic event group importances. 
System Study

Residual Heat Removal
2014 Update

December 2015 


\section{DATA TABLES}

Table 7. Plot data for RHR low-pressure injection mode start-only trend, Figure 5.

\begin{tabular}{ccccccc}
\hline & \multicolumn{2}{c}{ Regression Curve Data Points } & \multicolumn{2}{c}{ Annual Estimate Data Points } \\
\cline { 2 - 7 } FY/Source & Mean & $\begin{array}{c}\text { Lower } \\
\mathbf{( 5 \% )}\end{array}$ & $\begin{array}{c}\text { Upper } \\
\mathbf{( 9 5 \% )}\end{array}$ & $\begin{array}{c}\text { Lower } \\
\mathbf{( 5 \% )}\end{array}$ & $\begin{array}{c}\text { Upper } \\
\mathbf{( 9 5 \% )}\end{array}$ & Mean \\
\hline Industry & & & & $7.08 \mathrm{E}-06$ & $8.57 \mathrm{E}-04$ & $2.60 \mathrm{E}-04$ \\
1998 & & & & $1.42 \mathrm{E}-05$ & $8.83 \mathrm{E}-04$ & $2.71 \mathrm{E}-04$ \\
\hline 1999 & & & & $1.18 \mathrm{E}-05$ & $8.73 \mathrm{E}-04$ & $2.57 \mathrm{E}-04$ \\
\hline 2000 & & & & $1.34 \mathrm{E}-05$ & $8.80 \mathrm{E}-04$ & $2.65 \mathrm{E}-04$ \\
\hline 2001 & & & & $1.19 \mathrm{E}-05$ & $8.77 \mathrm{E}-04$ & $2.56 \mathrm{E}-04$ \\
\hline 2002 & & & & $7.66 \mathrm{E}-06$ & $8.59 \mathrm{E}-04$ & $2.43 \mathrm{E}-04$ \\
\hline 2003 & & & & $1.16 \mathrm{E}-05$ & $8.72 \mathrm{E}-04$ & $2.54 \mathrm{E}-04$ \\
\hline 2004 & & & & $1.03 \mathrm{E}-05$ & $8.68 \mathrm{E}-04$ & $2.46 \mathrm{E}-04$ \\
\hline 2005 & $2.61 \mathrm{E}-04$ & $2.48 \mathrm{E}-04$ & $2.75 \mathrm{E}-04$ & $1.14 \mathrm{E}-05$ & $8.69 \mathrm{E}-04$ & $2.55 \mathrm{E}-04$ \\
\hline 2006 & $2.58 \mathrm{E}-04$ & $2.47 \mathrm{E}-04$ & $2.69 \mathrm{E}-04$ & $9.87 \mathrm{E}-06$ & $8.70 \mathrm{E}-04$ & $2.62 \mathrm{E}-04$ \\
\hline 2007 & $2.55 \mathrm{E}-04$ & $2.46 \mathrm{E}-04$ & $2.64 \mathrm{E}-04$ & $1.25 \mathrm{E}-05$ & $8.75 \mathrm{E}-04$ & $2.68 \mathrm{E}-04$ \\
\hline 2008 & $2.52 \mathrm{E}-04$ & $2.45 \mathrm{E}-04$ & $2.60 \mathrm{E}-04$ & $8.73 \mathrm{E}-06$ & $8.65 \mathrm{E}-04$ & $2.46 \mathrm{E}-04$ \\
\hline 2009 & $2.49 \mathrm{E}-04$ & $2.43 \mathrm{E}-04$ & $2.56 \mathrm{E}-04$ & $7.58 \mathrm{E}-06$ & $8.60 \mathrm{E}-04$ & $2.43 \mathrm{E}-04$ \\
\hline 2010 & $2.46 \mathrm{E}-04$ & $2.40 \mathrm{E}-04$ & $2.53 \mathrm{E}-04$ & $9.47 \mathrm{E}-06$ & $8.64 \mathrm{E}-04$ & $2.55 \mathrm{E}-04$ \\
\hline 2011 & $2.44 \mathrm{E}-04$ & $2.37 \mathrm{E}-04$ & $2.51 \mathrm{E}-04$ & $6.89 \mathrm{E}-06$ & $8.57 \mathrm{E}-04$ & $2.35 \mathrm{E}-04$ \\
\hline 2012 & $2.41 \mathrm{E}-04$ & $2.32 \mathrm{E}-04$ & $2.49 \mathrm{E}-04$ & $6.02 \mathrm{E}-06$ & $8.55 \mathrm{E}-04$ & $2.36 \mathrm{E}-04$ \\
\hline 2013 & $2.38 \mathrm{E}-04$ & $2.28 \mathrm{E}-04$ & $2.48 \mathrm{E}-04$ & $8.15 \mathrm{E}-06$ & $8.66 \mathrm{E}-04$ & $2.43 \mathrm{E}-04$ \\
\hline 2014 & $2.35 \mathrm{E}-04$ & $2.23 \mathrm{E}-04$ & $2.47 \mathrm{E}-04$ & $6.11 \mathrm{E}-06$ & $8.56 \mathrm{E}-04$ & $2.37 \mathrm{E}-04$ \\
\hline
\end{tabular}


Table 8. Plot data for RHR low-pressure injection mode 8-hour trend, Figure 6.

\begin{tabular}{|c|c|c|c|c|c|c|}
\hline \multirow[b]{2}{*}{ FY/Source } & \multicolumn{3}{|c|}{ Regression Curve Data Points } & \multicolumn{3}{|c|}{ Annual Estimate Data Points } \\
\hline & Mean & $\begin{array}{c}\text { Lower } \\
(5 \%)\end{array}$ & $\begin{array}{l}\text { Upper } \\
(95 \%)\end{array}$ & $\begin{array}{c}\text { Lower } \\
(5 \%)\end{array}$ & $\begin{array}{l}\text { Upper } \\
(95 \%)\end{array}$ & Mean \\
\hline Industry & & & & $1.07 \mathrm{E}-05$ & 8.96E-04 & 3.07E-04 \\
\hline 1998 & & & & 1.71E-05 & 9.37E-04 & 3.27E-04 \\
\hline 1999 & & & & 1.46E-05 & 9.21E-04 & 3.13E-04 \\
\hline 2000 & & & & $1.66 \mathrm{E}-05$ & 9.31E-04 & $3.24 \mathrm{E}-04$ \\
\hline 2001 & & & & 1.39E-05 & $9.14 \mathrm{E}-04$ & 3.10E-04 \\
\hline 2002 & & & & 1.20E-05 & 8.97E-04 & 2.97E-04 \\
\hline 2003 & & & & 1.46E-05 & 9.19E-04 & 3.08E-04 \\
\hline 2004 & & & & 1.29E-05 & $9.05 \mathrm{E}-04$ & 3.01E-04 \\
\hline 2005 & 3.07E-04 & 2.91E-04 & 3.23E-04 & $1.44 \mathrm{E}-05$ & 9.01E-04 & 3.03E-04 \\
\hline 2006 & 3.04E-04 & 2.91E-04 & 3.18E-04 & 1.33E-05 & 9.01E-04 & 3.05E-04 \\
\hline 2007 & 3.02E-04 & $2.91 \mathrm{E}-04$ & 3.13E-04 & $1.66 \mathrm{E}-05$ & 9.32E-04 & 3.25E-04 \\
\hline 2008 & 3.00E-04 & 2.91E-04 & 3.09E-04 & 1.20E-05 & 9.03E-04 & 2.90E-04 \\
\hline 2009 & 2.98E-04 & $2.90 \mathrm{E}-04$ & 3.05E-04 & 1.10E-05 & 8.91E-04 & 2.87E-04 \\
\hline 2010 & 2.95E-04 & 2.88E-04 & 3.03E-04 & 1.26E-05 & 8.97E-04 & 2.97E-04 \\
\hline 2011 & 2.93E-04 & $2.85 \mathrm{E}-04$ & 3.02E-04 & 9.96E-06 & 8.85E-04 & 2.87E-04 \\
\hline 2012 & 2.91E-04 & 2.81E-04 & 3.02E-04 & 1.05E-05 & 8.97E-04 & 2.91E-04 \\
\hline 2013 & 2.89E-04 & 2.76E-04 & 3.02E-04 & 1.14E-05 & 9.08E-04 & 2.92E-04 \\
\hline 2014 & 2.87E-04 & 2.72E-04 & 3.02E-04 & 1.02E-05 & 8.93E-04 & $2.90 \mathrm{E}-04$ \\
\hline
\end{tabular}


Table 9. Plot data for RHR shutdown cooling mode start-only trend, Figure 7.

\begin{tabular}{ccccccc}
\hline & \multicolumn{2}{c}{ Regression Curve Data Points } & \multicolumn{3}{c}{ Annual Estimate Data Points } \\
\cline { 2 - 7 } FY/Source & Mean & $\begin{array}{c}\text { Lower } \\
\mathbf{( 5 \% )}\end{array}$ & $\begin{array}{c}\text { Upper } \\
\mathbf{( 9 5 \% )}\end{array}$ & $\begin{array}{c}\text { Lower } \\
\mathbf{( 5 \% )}\end{array}$ & $\begin{array}{c}\text { Upper } \\
\mathbf{( 9 5 \% )}\end{array}$ & Mean \\
\hline Industry & & & & $1.80 \mathrm{E}-04$ & $1.39 \mathrm{E}-02$ & $4.39 \mathrm{E}-03$ \\
1998 & & & & $2.25 \mathrm{E}-04$ & $1.57 \mathrm{E}-02$ & $5.22 \mathrm{E}-03$ \\
\hline 1999 & & & & $2.04 \mathrm{E}-04$ & $1.42 \mathrm{E}-02$ & $4.51 \mathrm{E}-03$ \\
\hline 2000 & & & & $2.10 \mathrm{E}-04$ & $1.46 \mathrm{E}-02$ & $4.68 \mathrm{E}-03$ \\
\hline 2001 & & & & $1.86 \mathrm{E}-04$ & $1.33 \mathrm{E}-02$ & $4.00 \mathrm{E}-03$ \\
\hline 2002 & & & & $1.85 \mathrm{E}-04$ & $1.31 \mathrm{E}-02$ & $4.18 \mathrm{E}-03$ \\
\hline 2003 & & & & $1.89 \mathrm{E}-04$ & $1.34 \mathrm{E}-02$ & $4.08 \mathrm{E}-03$ \\
\hline 2004 & & & & $1.74 \mathrm{E}-04$ & $1.27 \mathrm{E}-02$ & $3.85 \mathrm{E}-03$ \\
\hline 2005 & $5.11 \mathrm{E}-03$ & $4.24 \mathrm{E}-03$ & $6.15 \mathrm{E}-03$ & $2.01 \mathrm{E}-04$ & $1.41 \mathrm{E}-02$ & $4.57 \mathrm{E}-03$ \\
\hline 2006 & $4.93 \mathrm{E}-03$ & $4.22 \mathrm{E}-03$ & $5.76 \mathrm{E}-03$ & $2.21 \mathrm{E}-04$ & $1.57 \mathrm{E}-02$ & $5.39 \mathrm{E}-03$ \\
\hline 2007 & $4.75 \mathrm{E}-03$ & $4.18 \mathrm{E}-03$ & $5.40 \mathrm{E}-03$ & $2.35 \mathrm{E}-04$ & $1.61 \mathrm{E}-02$ & $5.50 \mathrm{E}-03$ \\
\hline 2008 & $4.58 \mathrm{E}-03$ & $4.13 \mathrm{E}-03$ & $5.09 \mathrm{E}-03$ & $1.77 \mathrm{E}-04$ & $1.29 \mathrm{E}-02$ & $4.07 \mathrm{E}-03$ \\
\hline 2009 & $4.42 \mathrm{E}-03$ & $4.03 \mathrm{E}-03$ & $4.85 \mathrm{E}-03$ & $1.90 \mathrm{E}-04$ & $1.33 \mathrm{E}-02$ & $4.29 \mathrm{E}-03$ \\
\hline 2010 & $4.26 \mathrm{E}-03$ & $3.89 \mathrm{E}-03$ & $4.68 \mathrm{E}-03$ & $2.13 \mathrm{E}-04$ & $1.48 \mathrm{E}-02$ & $4.99 \mathrm{E}-03$ \\
\hline 2011 & $4.11 \mathrm{E}-03$ & $3.70 \mathrm{E}-03$ & $4.57 \mathrm{E}-03$ & $1.57 \mathrm{E}-04$ & $1.19 \mathrm{E}-02$ & $3.57 \mathrm{E}-03$ \\
\hline 2012 & $3.97 \mathrm{E}-03$ & $3.49 \mathrm{E}-03$ & $4.51 \mathrm{E}-03$ & $1.63 \mathrm{E}-04$ & $1.23 \mathrm{E}-02$ & $3.86 \mathrm{E}-03$ \\
\hline 2013 & $3.83 \mathrm{E}-03$ & $3.27 \mathrm{E}-03$ & $4.47 \mathrm{E}-03$ & $1.70 \mathrm{E}-04$ & $1.23 \mathrm{E}-02$ & $3.77 \mathrm{E}-03$ \\
\hline 2014 & $3.69 \mathrm{E}-03$ & $3.06 \mathrm{E}-03$ & $4.45 \mathrm{E}-03$ & $1.63 \mathrm{E}-04$ & $1.23 \mathrm{E}-02$ & $3.88 \mathrm{E}-03$ \\
\hline
\end{tabular}


Table 10. Plot data for RHR shutdown cooling mode 24-hour trend, Figure 8.

\begin{tabular}{ccccccc}
\hline & \multicolumn{2}{c}{ Regression Curve Data Points } & \multicolumn{2}{c}{ Annual Estimate Data Points } \\
\cline { 2 - 7 } FY/Source & Mean & $\begin{array}{c}\text { Lower } \\
\mathbf{( 5 \% )}\end{array}$ & $\begin{array}{c}\text { Upper } \\
\mathbf{( 9 5 \% )}\end{array}$ & $\begin{array}{c}\text { Lower } \\
\mathbf{( 5 \% )}\end{array}$ & $\begin{array}{c}\text { Upper } \\
\mathbf{( 9 5 \% )}\end{array}$ & Mean \\
\hline Industry & & & & $2.23 \mathrm{E}-04$ & $1.44 \mathrm{E}-02$ & $4.57 \mathrm{E}-03$ \\
1998 & & & & $2.76 \mathrm{E}-04$ & $1.61 \mathrm{E}-02$ & $5.37 \mathrm{E}-03$ \\
1999 & & & & $2.46 \mathrm{E}-04$ & $1.45 \mathrm{E}-02$ & $4.64 \mathrm{E}-03$ \\
2000 & & & & $2.61 \mathrm{E}-04$ & $1.53 \mathrm{E}-02$ & $4.87 \mathrm{E}-03$ \\
\hline 2001 & & & & $2.27 \mathrm{E}-04$ & $1.37 \mathrm{E}-02$ & $4.14 \mathrm{E}-03$ \\
2002 & & & & $2.35 \mathrm{E}-04$ & $1.41 \mathrm{E}-02$ & $4.44 \mathrm{E}-03$ \\
\hline 2003 & & & & $2.54 \mathrm{E}-04$ & $1.49 \mathrm{E}-02$ & $4.40 \mathrm{E}-03$ \\
\hline 2004 & & & & $2.20 \mathrm{E}-04$ & $1.34 \mathrm{E}-02$ & $4.02 \mathrm{E}-03$ \\
\hline 2005 & $5.30 \mathrm{E}-03$ & $4.45 \mathrm{E}-03$ & $6.30 \mathrm{E}-03$ & $2.50 \mathrm{E}-04$ & $1.49 \mathrm{E}-02$ & $4.77 \mathrm{E}-03$ \\
\hline 2006 & $5.12 \mathrm{E}-03$ & $4.42 \mathrm{E}-03$ & $5.92 \mathrm{E}-03$ & $2.74 \mathrm{E}-04$ & $1.62 \mathrm{E}-02$ & $5.55 \mathrm{E}-03$ \\
\hline 2007 & $4.95 \mathrm{E}-03$ & $4.39 \mathrm{E}-03$ & $5.57 \mathrm{E}-03$ & $2.99 \mathrm{E}-04$ & $1.70 \mathrm{E}-02$ & $5.75 \mathrm{E}-03$ \\
\hline 2008 & $4.78 \mathrm{E}-03$ & $4.33 \mathrm{E}-03$ & $5.27 \mathrm{E}-03$ & $2.29 \mathrm{E}-04$ & $1.37 \mathrm{E}-02$ & $4.24 \mathrm{E}-03$ \\
\hline 2009 & $4.62 \mathrm{E}-03$ & $4.24 \mathrm{E}-03$ & $5.03 \mathrm{E}-03$ & $2.33 \mathrm{E}-04$ & $1.39 \mathrm{E}-02$ & $4.46 \mathrm{E}-03$ \\
\hline 2010 & $4.46 \mathrm{E}-03$ & $4.09 \mathrm{E}-03$ & $4.87 \mathrm{E}-03$ & $2.56 \mathrm{E}-04$ & $1.51 \mathrm{E}-02$ & $5.10 \mathrm{E}-03$ \\
\hline 2011 & $4.31 \mathrm{E}-03$ & $3.91 \mathrm{E}-03$ & $4.76 \mathrm{E}-03$ & $2.04 \mathrm{E}-04$ & $1.26 \mathrm{E}-02$ & $3.80 \mathrm{E}-03$ \\
\hline 2012 & $4.17 \mathrm{E}-03$ & $3.70 \mathrm{E}-03$ & $4.70 \mathrm{E}-03$ & $2.25 \mathrm{E}-04$ & $1.35 \mathrm{E}-02$ & $4.13 \mathrm{E}-03$ \\
\hline 2013 & $4.03 \mathrm{E}-03$ & $3.48 \mathrm{E}-03$ & $4.66 \mathrm{E}-03$ & $2.17 \mathrm{E}-04$ & $1.31 \mathrm{E}-02$ & $3.96 \mathrm{E}-03$ \\
\hline 2014 & $3.89 \mathrm{E}-03$ & $3.27 \mathrm{E}-03$ & $4.63 \mathrm{E}-03$ & $2.16 \mathrm{E}-04$ & $1.31 \mathrm{E}-02$ & $4.07 \mathrm{E}-03$ \\
\hline
\end{tabular}


Table 11. Basic event reliability trending data.

\begin{tabular}{|c|c|c|c|c|c|c|c|c|}
\hline \multirow{2}{*}{$\begin{array}{c}\text { Failure } \\
\text { Mode }\end{array}$} & \multirow[b]{2}{*}{ Component $^{\mathrm{a}}$} & \multirow[b]{2}{*}{ Year } & \multirow{2}{*}{$\begin{array}{l}\text { Number of } \\
\text { Failures }\end{array}$} & \multirow{2}{*}{$\begin{array}{l}\text { Demands/ } \\
\text { Run Hours }\end{array}$} & \multicolumn{4}{|c|}{ Bayesian Update } \\
\hline & & & & & Mean & Post A & Post B & Distribution \\
\hline FTOC & AOV & 1998 & 1 & 868 & $1.04 \mathrm{E}-03$ & 2.112 & 2035 & Beta \\
\hline FTOC & AOV & 1999 & 1 & 1031 & $9.60 \mathrm{E}-04$ & 2.112 & 2198 & Beta \\
\hline FTOC & AOV & 2000 & 0 & 878 & 5.43E-04 & 1.112 & 2046 & Beta \\
\hline FTOC & AOV & 2001 & 0 & 961 & $5.22 \mathrm{E}-04$ & 1.112 & 2129 & Beta \\
\hline FTOC & AOV & 2002 & 1 & 988 & 9.79E-04 & 2.112 & 2155 & Beta \\
\hline FTOC & AOV & 2003 & 1 & 973 & 9.86E-04 & 2.112 & 2140 & Beta \\
\hline FTOC & AOV & 2004 & 0 & 923 & 5.31E-04 & 1.112 & 2091 & Beta \\
\hline FTOC & AOV & 2005 & 0 & 838 & 5.54E-04 & 1.112 & 2006 & Beta \\
\hline FTOC & AOV & 2006 & 2 & 717 & 1.65E-03 & 3.112 & 1883 & Beta \\
\hline FTOC & AOV & 2007 & 1 & 737 & 1.11E-03 & 2.112 & 1904 & Beta \\
\hline FTOC & AOV & 2008 & 0 & 729 & 5.86E-04 & 1.112 & 1897 & Beta \\
\hline FTOC & AOV & 2009 & 1 & 726 & 1.11E-03 & 2.112 & 1893 & Beta \\
\hline FTOC & AOV & 2010 & 1 & 756 & 1.10E-03 & 2.112 & 1923 & Beta \\
\hline FTOC & AOV & 2011 & 0 & 738 & 5.83E-04 & 1.112 & 1906 & Beta \\
\hline FTOC & AOV & 2012 & 0 & 721 & 5.88E-04 & 1.112 & 1889 & Beta \\
\hline FTOC & AOV & 2013 & 0 & 734 & 5.84E-04 & 1.112 & 1902 & Beta \\
\hline FTOC & AOV & 2014 & 0 & 716 & 5.90E-04 & 1.112 & 1884 & Beta \\
\hline FTOC & MOV & 1998 & 17 & 11377 & 1.41E-03 & 19.046 & 13483 & Beta \\
\hline FTOC & MOV & 1999 & 14 & 13631 & 1.02E-03 & 16.046 & 15740 & Beta \\
\hline FTOC & MOV & 2000 & 16 & 13538 & 1.15E-03 & 18.046 & 15645 & Beta \\
\hline FTOC & MOV & 2001 & 10 & 13831 & 7.55E-04 & 12.046 & 15944 & Beta \\
\hline FTOC & MOV & 2002 & 12 & 13953 & 8.74E-04 & 14.046 & 16064 & Beta \\
\hline FTOC & MOV & 2003 & 10 & 13762 & 7.58E-04 & 12.046 & 15875 & Beta \\
\hline FTOC & MOV & 2004 & 8 & 12774 & 6.74E-04 & 10.046 & 14889 & Beta \\
\hline FTOC & MOV & 2005 & 14 & 12252 & 1.12E-03 & 16.046 & 14361 & Beta \\
\hline FTOC & MOV & 2006 & 16 & 9955 & 1.49E-03 & 18.046 & 12062 & Beta \\
\hline FTOC & MOV & 2007 & 17 & 9901 & 1.58E-03 & 19.046 & 12007 & Beta \\
\hline FTOC & MOV & 2008 & 8 & 9946 & 8.32E-04 & 10.046 & 12061 & Beta \\
\hline FTOC & MOV & 2009 & 9 & 9741 & 9.31E-04 & 11.046 & 11855 & Beta \\
\hline FTOC & MOV & 2010 & 14 & 10024 & 1.32E-03 & 16.046 & 12133 & Beta \\
\hline FTOC & MOV & 2011 & 5 & 10053 & 5.79E-04 & 7.046 & 12171 & Beta \\
\hline FTOC & MOV & 2012 & 7 & 9992 & 7.47E-04 & 9.046 & 12108 & Beta \\
\hline FTOC & MOV & 2013 & 6 & 10041 & 6.61E-04 & 8.046 & 12158 & Beta \\
\hline FTOC & MOV & 2014 & 7 & 9957 & 7.49E-04 & 9.046 & 12073 & Beta \\
\hline FTOP & AOV & 1998 & 0 & 1314000 & 2.02E-07 & 1.421 & 7033000 & Gamma \\
\hline FTOP & AOV & 1999 & 0 & 1314000 & 2.02E-07 & 1.421 & 7033000 & Gamma \\
\hline FTOP & AOV & 2000 & 0 & 1314000 & 2.02E-07 & 1.421 & 7033000 & Gamma \\
\hline FTOP & AOV & 2001 & 0 & 1314000 & 2.02E-07 & 1.421 & 7033000 & Gamma \\
\hline FTOP & AOV & 2002 & 0 & 1314000 & 2.02E-07 & 1.421 & 7033000 & Gamma \\
\hline FTOP & AOV & 2003 & 0 & 1314000 & 2.02E-07 & 1.421 & 7033000 & Gamma \\
\hline FTOP & AOV & 2004 & 0 & 1314000 & 2.02E-07 & 1.421 & 7033000 & Gamma \\
\hline
\end{tabular}


Table 11. (continued).

\begin{tabular}{|c|c|c|c|c|c|c|c|c|}
\hline \multirow{2}{*}{$\begin{array}{c}\text { Failure } \\
\text { Mode }\end{array}$} & \multirow[b]{2}{*}{ Component $^{a}$} & \multirow[b]{2}{*}{ Year } & \multirow{2}{*}{$\begin{array}{l}\text { Number of } \\
\text { Failures }\end{array}$} & \multirow{2}{*}{$\begin{array}{l}\text { Demands/ } \\
\text { Run Hours }\end{array}$} & \multicolumn{4}{|c|}{ Bayesian Update } \\
\hline & & & & & Mean & Post A & Post B & Distribution \\
\hline FTOP & AOV & 2005 & 0 & 1314000 & 2.02E-07 & 1.421 & 7033000 & Gamma \\
\hline FTOP & AOV & 2006 & 0 & 1314000 & 2.02E-07 & 1.421 & 7033000 & Gamma \\
\hline FTOP & AOV & 2007 & 0 & 1314000 & 2.02E-07 & 1.421 & 7033000 & Gamma \\
\hline FTOP & AOV & 2008 & 0 & 1314000 & 2.02E-07 & 1.421 & 7033000 & Gamma \\
\hline FTOP & AOV & 2009 & 0 & 1314000 & 2.02E-07 & 1.421 & 7033000 & Gamma \\
\hline FTOP & AOV & 2010 & 0 & 1314000 & 2.02E-07 & 1.421 & 7033000 & Gamma \\
\hline FTOP & AOV & 2011 & 0 & 1314000 & 2.02E-07 & 1.421 & 7033000 & Gamma \\
\hline FTOP & AOV & 2012 & 0 & 1314000 & 2.02E-07 & 1.421 & 7033000 & Gamma \\
\hline FTOP & AOV & 2013 & 0 & 1314000 & 2.02E-07 & 1.421 & 7033000 & Gamma \\
\hline FTOP & AOV & 2014 & 0 & 1314000 & 2.02E-07 & 1.421 & 7033000 & Gamma \\
\hline FTOP & MOV & 1998 & 1 & 15741720 & 6.50E-08 & 2.458 & 37791720 & Gamma \\
\hline FTOP & MOV & 1999 & 3 & 15881880 & 1.18E-07 & 4.458 & 37931880 & Gamma \\
\hline FTOP & MOV & 2000 & 6 & 15881880 & 1.97E-07 & 7.458 & 37931880 & Gamma \\
\hline FTOP & MOV & 2001 & 1 & 15881880 & 6.48E-08 & 2.458 & 37931880 & Gamma \\
\hline FTOP & MOV & 2002 & 0 & 15881880 & 3.84E-08 & 1.458 & 37931880 & Gamma \\
\hline FTOP & MOV & 2003 & 2 & 15916920 & 9.11E-08 & 3.458 & 37966920 & Gamma \\
\hline FTOP & MOV & 2004 & 0 & 15890640 & 3.84E-08 & 1.458 & 37940640 & Gamma \\
\hline FTOP & MOV & 2005 & 0 & 15890640 & 3.84E-08 & 1.458 & 37940640 & Gamma \\
\hline FTOP & MOV & 2006 & 1 & 15890640 & 6.48E-08 & 2.458 & 37940640 & Gamma \\
\hline FTOP & MOV & 2007 & 1 & 15881880 & $6.48 \mathrm{E}-08$ & 2.458 & 37931880 & Gamma \\
\hline FTOP & MOV & 2008 & 0 & 15873120 & 3.84E-08 & 1.458 & 37923120 & Gamma \\
\hline FTOP & MOV & 2009 & 0 & 15873120 & 3.84E-08 & 1.458 & 37923120 & Gamma \\
\hline FTOP & MOV & 2010 & 1 & 15873120 & 6.48E-08 & 2.458 & 37923120 & Gamma \\
\hline FTOP & MOV & 2011 & 0 & 16109640 & 3.82E-08 & 1.458 & 38159640 & Gamma \\
\hline FTOP & MOV & 2012 & 1 & 15951960 & 6.47E-08 & 2.458 & 38001960 & Gamma \\
\hline FTOP & MOV & 2013 & 2 & 15951960 & $9.10 \mathrm{E}-08$ & 3.458 & 38001960 & Gamma \\
\hline FTOP & MOV & 2014 & 0 & 15925680 & 3.84E-08 & 1.458 & 37975680 & Gamma \\
\hline $\mathrm{FTR}<1 \mathrm{H}$ & MDP & 1998 & 0 & 4537 & 9.42E-05 & 1.820 & 19327 & Gamma \\
\hline $\mathrm{FTR}<1 \mathrm{H}$ & MDP & 1999 & 1 & 4690 & 1.45E-04 & 2.820 & 19480 & Gamma \\
\hline $\mathrm{FTR}<1 \mathrm{H}$ & MDP & 2000 & 2 & 4703 & 1.96E-04 & 3.820 & 19493 & Gamma \\
\hline $\mathrm{FTR}<1 \mathrm{H}$ & MDP & 2001 & 0 & 4570 & 9.40E-05 & 1.820 & 19360 & Gamma \\
\hline $\mathrm{FTR}<1 \mathrm{H}$ & MDP & 2002 & 1 & 4765 & 1.44E-04 & 2.820 & 19555 & Gamma \\
\hline $\mathrm{FTR}<1 \mathrm{H}$ & MDP & 2003 & 0 & 5182 & 9.11E-05 & 1.820 & 19972 & Gamma \\
\hline $\mathrm{FTR}<1 \mathrm{H}$ & MDP & 2004 & 0 & 5124 & 9.14E-05 & 1.820 & 19914 & Gamma \\
\hline $\mathrm{FTR}<1 \mathrm{H}$ & MDP & 2005 & 0 & 5414 & 9.01E-05 & 1.820 & 20204 & Gamma \\
\hline $\mathrm{FTR}<1 \mathrm{H}$ & MDP & 2006 & 0 & 4987 & $9.20 \mathrm{E}-05$ & 1.820 & 19777 & Gamma \\
\hline $\mathrm{FTR}<1 \mathrm{H}$ & MDP & 2007 & 0 & 5232 & 9.09E-05 & 1.820 & 20022 & Gamma \\
\hline $\mathrm{FTR}<1 \mathrm{H}$ & MDP & 2008 & 0 & 5082 & 9.16E-05 & 1.820 & 19872 & Gamma \\
\hline $\mathrm{FTR}<1 \mathrm{H}$ & MDP & 2009 & 0 & 5143 & 9.13E-05 & 1.820 & 19933 & Gamma \\
\hline $\mathrm{FTR}<1 \mathrm{H}$ & MDP & 2010 & 0 & 5253 & 9.08E-05 & 1.820 & 20043 & Gamma \\
\hline $\mathrm{FTR}<1 \mathrm{H}$ & MDP & 2011 & 0 & 4979 & 9.21E-05 & 1.820 & 19769 & Gamma \\
\hline
\end{tabular}


Table 11. (continued).

\begin{tabular}{|c|c|c|c|c|c|c|c|c|}
\hline \multirow{2}{*}{$\begin{array}{c}\text { Failure } \\
\text { Mode }\end{array}$} & \multirow[b]{2}{*}{ Component $^{a}$} & \multirow[b]{2}{*}{ Year } & \multirow{2}{*}{$\begin{array}{l}\text { Number of } \\
\text { Failures }\end{array}$} & \multirow{2}{*}{$\begin{array}{l}\text { Demands/ } \\
\text { Run Hours }\end{array}$} & \multicolumn{4}{|c|}{ Bayesian Update } \\
\hline & & & & & Mean & Post A & Post B & Distribution \\
\hline $\mathrm{FTR}<1 \mathrm{H}$ & MDP & 2012 & 1 & 5077 & 1.42E-04 & 2.820 & 19867 & Gamma \\
\hline $\mathrm{FTR}<1 \mathrm{H}$ & MDP & 2013 & 1 & 5253 & 1.41E-04 & 2.820 & 20043 & Gamma \\
\hline $\mathrm{FTR}<1 \mathrm{H}$ & MDP & 2014 & 2 & 4903 & 1.94E-04 & 3.820 & 19693 & Gamma \\
\hline $\mathrm{FTR}>1 \mathrm{H}$ & MDP & 1998 & 1 & 101829 & 1.01E-05 & 1.781 & 176839 & Gamma \\
\hline FTR $>1 \mathrm{H}$ & MDP & 1999 & 0 & 80909 & 5.01E-06 & 0.781 & 155919 & Gamma \\
\hline FTR $>1 \mathrm{H}$ & MDP & 2000 & 1 & 54515 & 1.38E-05 & 1.781 & 129525 & Gamma \\
\hline $\mathrm{FTR}>1 \mathrm{H}$ & MDP & 2001 & 0 & 64853 & 5.58E-06 & 0.781 & 139864 & Gamma \\
\hline $\mathrm{FTR}>1 \mathrm{H}$ & MDP & 2002 & 3 & 53175 & $2.95 \mathrm{E}-05$ & 3.781 & 128185 & Gamma \\
\hline $\mathrm{FTR}>1 \mathrm{H}$ & MDP & 2003 & 6 & 62061 & 4.95E-05 & 6.781 & 137072 & Gamma \\
\hline FTR $>1 \mathrm{H}$ & MDP & 2004 & 2 & 46351 & 2.29E-05 & 2.781 & 121361 & Gamma \\
\hline $\mathrm{FTR}>1 \mathrm{H}$ & MDP & 2005 & 1 & 53193 & 1.39E-05 & 1.781 & 128203 & Gamma \\
\hline $\mathrm{FTR}>1 \mathrm{H}$ & MDP & 2006 & 0 & 43873 & 6.57E-06 & 0.781 & 118883 & Gamma \\
\hline $\mathrm{FTR}>1 \mathrm{H}$ & MDP & 2007 & 3 & 47807 & $3.08 \mathrm{E}-05$ & 3.781 & 122817 & Gamma \\
\hline $\mathrm{FTR}>1 \mathrm{H}$ & MDP & 2008 & 2 & 47863 & 2.26E-05 & 2.781 & 122873 & Gamma \\
\hline $\mathrm{FTR}>1 \mathrm{H}$ & MDP & 2009 & 1 & 44270 & 1.49E-05 & 1.781 & 119280 & Gamma \\
\hline $\mathrm{FTR}>1 \mathrm{H}$ & MDP & 2010 & 0 & 48434 & 6.33E-06 & 0.781 & 123444 & Gamma \\
\hline $\mathrm{FTR}>1 \mathrm{H}$ & MDP & 2011 & 2 & 48201 & 2.26E-05 & 2.781 & 123211 & Gamma \\
\hline $\mathrm{FTR}>1 \mathrm{H}$ & MDP & 2012 & 4 & 54123 & 3.70E-05 & 4.781 & 129133 & Gamma \\
\hline $\mathrm{FTR}>1 \mathrm{H}$ & MDP & 2013 & 2 & 51875 & 2.19E-05 & 2.781 & 126885 & Gamma \\
\hline $\mathrm{FTR}>1 \mathrm{H}$ & MDP & 2014 & 1 & 45574 & $1.48 \mathrm{E}-05$ & 1.781 & 120584 & Gamma \\
\hline FTS & MDP & 1998 & 6 & 4537 & $1.21 \mathrm{E}-03$ & 7.948 & 6585 & Beta \\
\hline FTS & MDP & 1999 & 5 & 4690 & 1.03E-03 & 6.948 & 6739 & Beta \\
\hline FTS & MDP & 2000 & 6 & 4703 & 1.18E-03 & 7.948 & 6751 & Beta \\
\hline FTS & MDP & 2001 & 6 & 4570 & 1.20E-03 & 7.948 & 6618 & Beta \\
\hline FTS & MDP & 2002 & 2 & 4765 & 5.79E-04 & 3.948 & 6817 & Beta \\
\hline FTS & MDP & 2003 & 6 & 5182 & 1.10E-03 & 7.948 & 7230 & Beta \\
\hline FTS & MDP & 2004 & 5 & 5124 & $9.68 \mathrm{E}-04$ & 6.948 & 7173 & Beta \\
\hline FTS & MDP & 2005 & 5 & 5414 & $9.30 \mathrm{E}-04$ & 6.948 & 7463 & Beta \\
\hline FTS & MDP & 2006 & 3 & 4987 & 7.03E-04 & 4.948 & 7038 & Beta \\
\hline FTS & MDP & 2007 & 5 & 5232 & 9.53E-04 & 6.948 & 7281 & Beta \\
\hline FTS & MDP & 2008 & 3 & 5082 & $6.93 \mathrm{E}-04$ & 4.948 & 7133 & Beta \\
\hline FTS & MDP & 2009 & 2 & 5143 & 5.48E-04 & 3.948 & 7195 & Beta \\
\hline FTS & MDP & 2010 & 3 & 5253 & 6.77E-04 & 4.948 & 7304 & Beta \\
\hline FTS & MDP & 2011 & 2 & 4979 & 5.61E-04 & 3.948 & 7031 & Beta \\
\hline FTS & MDP & 2012 & 1 & 5077 & 4.13E-04 & 2.948 & 7130 & Beta \\
\hline FTS & MDP & 2013 & 3 & 5253 & 6.77E-04 & 4.948 & 7304 & Beta \\
\hline FTS & MDP & 2014 & 1 & 4903 & 4.24E-04 & 2.948 & 6956 & Beta \\
\hline LOHT & HTX & 1998 & 0 & 0 & $5.23 \mathrm{E}-07$ & 16.500 & 31564650 & Gamma \\
\hline LOHT & HTX & 1999 & 0 & 0 & 5.23E-07 & 16.500 & 31564650 & Gamma \\
\hline LOHT & HTX & 2000 & 0 & 0 & $5.23 \mathrm{E}-07$ & 16.500 & 31564650 & Gamma \\
\hline LOHT & HTX & 2001 & 2 & 0 & 5.86E-07 & 18.500 & 31564650 & Gamma \\
\hline
\end{tabular}


Table 11. (continued).

\begin{tabular}{|c|c|c|c|c|c|c|c|c|}
\hline \multirow{2}{*}{$\begin{array}{c}\text { Failure } \\
\text { Mode }\end{array}$} & \multirow[b]{2}{*}{ Component $^{\mathrm{a}}$} & \multirow[b]{2}{*}{ Year } & \multirow{2}{*}{$\begin{array}{l}\text { Number of } \\
\text { Failures }\end{array}$} & \multirow{2}{*}{$\begin{array}{l}\text { Demands/ } \\
\text { Run Hours }\end{array}$} & \multicolumn{4}{|c|}{ Bayesian Update } \\
\hline & & & & & Mean & Post A & Post B & Distribution \\
\hline LOHT & HTX & 2002 & 0 & 0 & $5.23 \mathrm{E}-07$ & 16.500 & 31564650 & Gamma \\
\hline LOHT & HTX & 2003 & 0 & 0 & $5.23 \mathrm{E}-07$ & 16.500 & 31564650 & Gamma \\
\hline LOHT & HTX & 2004 & 0 & 0 & 5.23E-07 & 16.500 & 31564650 & Gamma \\
\hline LOHT & HTX & 2005 & 0 & 0 & $5.23 \mathrm{E}-07$ & 16.500 & 31564650 & Gamma \\
\hline LOHT & HTX & 2006 & 0 & 0 & $5.23 \mathrm{E}-07$ & 16.500 & 31564650 & Gamma \\
\hline LOHT & HTX & 2007 & 0 & 0 & 5.23E-07 & 16.500 & 31564650 & Gamma \\
\hline LOHT & HTX & 2008 & 0 & 0 & 5.23E-07 & 16.500 & 31564650 & Gamma \\
\hline LOHT & HTX & 2009 & 0 & 0 & $5.23 \mathrm{E}-07$ & 16.500 & 31564650 & Gamma \\
\hline LOHT & HTX & 2010 & 0 & 0 & $5.23 \mathrm{E}-07$ & 16.500 & 31564650 & Gamma \\
\hline LOHT & HTX & 2011 & 0 & 0 & $5.23 \mathrm{E}-07$ & 16.500 & 31564650 & Gamma \\
\hline LOHT & HTX & 2012 & 0 & 0 & $5.23 \mathrm{E}-07$ & 16.500 & 31564650 & Gamma \\
\hline LOHT & HTX & 2013 & 0 & 0 & $5.23 \mathrm{E}-07$ & 16.500 & 31564650 & Gamma \\
\hline LOHT & HTX & 2014 & 0 & 0 & $5.23 \mathrm{E}-07$ & 16.500 & 31564650 & Gamma \\
\hline so & AOV & 1998 & 0 & 1314000 & 1.04E-07 & 0.680 & 6525000 & Gamma \\
\hline SO & AOV & 1999 & 0 & 1314000 & $1.04 \mathrm{E}-07$ & 0.680 & 6525000 & Gamma \\
\hline SO & AOV & 2000 & 0 & 1314000 & 1.04E-07 & 0.680 & 6525000 & Gamma \\
\hline SO & AOV & 2001 & 0 & 1314000 & $1.04 \mathrm{E}-07$ & 0.680 & 6525000 & Gamma \\
\hline SO & AOV & 2002 & 0 & 1314000 & $1.04 \mathrm{E}-07$ & 0.680 & 6525000 & Gamma \\
\hline SO & AOV & 2003 & 0 & 1314000 & $1.04 \mathrm{E}-07$ & 0.680 & 6525000 & Gamma \\
\hline SO & AOV & 2004 & 0 & 1314000 & $1.04 \mathrm{E}-07$ & 0.680 & 6525000 & Gamma \\
\hline SO & AOV & 2005 & 0 & 1314000 & 1.04E-07 & 0.680 & 6525000 & Gamma \\
\hline SO & AOV & 2006 & 0 & 1314000 & $1.04 \mathrm{E}-07$ & 0.680 & 6525000 & Gamma \\
\hline SO & AOV & 2007 & 0 & 1314000 & $1.04 \mathrm{E}-07$ & 0.680 & 6525000 & Gamma \\
\hline SO & AOV & 2008 & 1 & 1314000 & $2.57 \mathrm{E}-07$ & 1.680 & 6525000 & Gamma \\
\hline SO & AOV & 2009 & 0 & 1314000 & 1.04E-07 & 0.680 & 6525000 & Gamma \\
\hline SO & AOV & 2010 & 0 & 1314000 & $1.04 \mathrm{E}-07$ & 0.680 & 6525000 & Gamma \\
\hline SO & AOV & 2011 & 0 & 1314000 & $1.04 \mathrm{E}-07$ & 0.680 & 6525000 & Gamma \\
\hline SO & AOV & 2012 & 0 & 1314000 & $1.04 \mathrm{E}-07$ & 0.680 & 6525000 & Gamma \\
\hline SO & AOV & 2013 & 1 & 1314000 & $2.57 \mathrm{E}-07$ & 1.680 & 6525000 & Gamma \\
\hline SO & AOV & 2014 & 0 & 1314000 & $1.04 \mathrm{E}-07$ & 0.680 & 6525000 & Gamma \\
\hline SO & MOV & 1998 & 3 & 15741720 & 1.10E-07 & 3.570 & 32581720 & Gamma \\
\hline SO & MOV & 1999 & 0 & 15881880 & $1.74 \mathrm{E}-08$ & 0.570 & 32721880 & Gamma \\
\hline SO & MOV & 2000 & 2 & 15881880 & 7.85E-08 & 2.570 & 32721880 & Gamma \\
\hline SO & MOV & 2001 & 0 & 15881880 & $1.74 \mathrm{E}-08$ & 0.570 & 32721880 & Gamma \\
\hline SO & MOV & 2002 & 0 & 15881880 & $1.74 \mathrm{E}-08$ & 0.570 & 32721880 & Gamma \\
\hline SO & MOV & 2003 & 1 & 15916920 & 4.79E-08 & 1.570 & 32756920 & Gamma \\
\hline SO & MOV & 2004 & 0 & 15890640 & $1.74 \mathrm{E}-08$ & 0.570 & 32730640 & Gamma \\
\hline SO & MOV & 2005 & 0 & 15890640 & $1.74 \mathrm{E}-08$ & 0.570 & 32730640 & Gamma \\
\hline SO & MOV & 2006 & 0 & 15890640 & $1.74 \mathrm{E}-08$ & 0.570 & 32730640 & Gamma \\
\hline SO & MOV & 2007 & 1 & 15881880 & 4.80E-08 & 1.570 & 32721880 & Gamma \\
\hline SO & MOV & 2008 & 0 & 15873120 & $1.74 \mathrm{E}-08$ & 0.570 & 32713120 & Gamma \\
\hline
\end{tabular}


Table 11. (continued).

\begin{tabular}{|c|c|c|c|c|c|c|c|c|}
\hline \multirow{2}{*}{$\begin{array}{c}\text { Failure } \\
\text { Mode }\end{array}$} & \multirow[b]{2}{*}{ Component $^{\mathrm{a}}$} & \multirow[b]{2}{*}{ Year } & \multirow{2}{*}{$\begin{array}{l}\text { Number of } \\
\text { Failures }\end{array}$} & \multirow{2}{*}{$\begin{array}{l}\text { Demands/ } \\
\text { Run Hours }\end{array}$} & \multicolumn{4}{|c|}{ Bayesian Update } \\
\hline & & & & & Mean & Post A & Post B & Distribution \\
\hline SO & MOV & 2009 & 0 & 15873120 & $1.74 \mathrm{E}-08$ & 0.570 & 32713120 & Gamma \\
\hline SO & MOV & 2010 & 0 & 15873120 & 1.74E-08 & 0.570 & 32713120 & Gamma \\
\hline SO & MOV & 2011 & 0 & 16109640 & $1.73 \mathrm{E}-08$ & 0.570 & 32949640 & Gamma \\
\hline SO & MOV & 2012 & 0 & 15951960 & $1.74 \mathrm{E}-08$ & 0.570 & 32791960 & Gamma \\
\hline SO & MOV & 2013 & 1 & 15951960 & 4.79E-08 & 1.570 & 32791960 & Gamma \\
\hline SO & MOV & 2014 & 0 & 15925680 & 1.74E-08 & 0.570 & 32765680 & Gamma \\
\hline $\begin{array}{ll}\text { a. } & \text { AOV } \\
\text { HTX } \\
\text { LOHT } \\
\text { MDP } \\
\text { MOV }\end{array}$ & $\begin{array}{l}=\text { air-operated va } \\
=\text { heat exchange } \\
=\text { loss of heat tra } \\
=\text { motor-driven p } \\
=\text { motor-operatec }\end{array}$ & $\begin{array}{l}\text { ve } \\
\text { sfer } \\
\mathrm{mp} \\
\text { valve. }\end{array}$ & & & & & & \\
\hline
\end{tabular}


Table 12. Basic event UA trending data.

\begin{tabular}{|c|c|c|c|c|c|c|c|c|}
\hline \multirow{2}{*}{$\begin{array}{c}\text { Failure } \\
\text { Mode }\end{array}$} & \multirow[b]{2}{*}{ Component } & \multirow[b]{2}{*}{ Year } & \multirow[b]{2}{*}{ UA Hours } & \multirow{2}{*}{$\begin{array}{l}\text { Critical } \\
\text { Hours }\end{array}$} & \multicolumn{4}{|c|}{ Bayesian Update } \\
\hline & & & & & Mean & Post A & Post B & Distribution \\
\hline UA & HDR & 2002 & 46.210 & 76298 & $6.50 \mathrm{E}-04$ & 0.313 & 480.8 & Beta \\
\hline UA & HDR & 2003 & 82.450 & 104108 & 5.42E-04 & 0.391 & 721.6 & Beta \\
\hline UA & HDR & 2004 & 97.290 & 135846 & $6.22 \mathrm{E}-04$ & 0.239 & 384.1 & Beta \\
\hline UA & HDR & 2005 & 57.280 & 127718 & $3.90 \mathrm{E}-04$ & 0.647 & 1656.7 & Beta \\
\hline UA & HDR & 2006 & 61.720 & 128166 & 4.63E-04 & 0.209 & 450.8 & Beta \\
\hline UA & HDR & 2007 & 87.360 & 132783 & $5.22 \mathrm{E}-04$ & 0.386 & 738.8 & Beta \\
\hline UA & HDR & 2008 & 72.520 & 131153 & 4.88E-04 & 0.289 & 592.6 & Beta \\
\hline UA & HDR & 2009 & 83.740 & 130048 & $6.13 \mathrm{E}-04$ & 0.171 & 279.6 & Beta \\
\hline UA & HDR & 2010 & 50.700 & 121815 & 3.35E-04 & 0.358 & 1067.4 & Beta \\
\hline UA & HDR & 2011 & 69.600 & 118160 & 4.94E-04 & 0.245 & 496.0 & Beta \\
\hline UA & HDR & 2012 & 148.650 & 117699 & 1.15E-03 & 0.202 & 175.3 & Beta \\
\hline UA & HDR & 2013 & 157.450 & 119651 & 1.26E-03 & 0.187 & 148.2 & Beta \\
\hline UA & HDR & 2014 & 133.460 & 119441 & 1.19E-03 & 0.177 & 148.6 & Beta \\
\hline UA & HTX & 2002 & 25.270 & 50600 & 4.87E-04 & 0.485 & 995.0 & Beta \\
\hline UA & HTX & 2003 & 76.800 & 64793 & 1.17E-03 & 0.564 & 479.4 & Beta \\
\hline UA & HTX & 2004 & 121.880 & 68060 & 1.78E-03 & 0.882 & 493.4 & Beta \\
\hline UA & HTX & 2005 & 89.070 & 63664 & 1.32E-03 & 0.613 & 462.4 & Beta \\
\hline UA & HTX & 2006 & 138.760 & 63550 & 2.13E-03 & 1.647 & 771.7 & Beta \\
\hline UA & HTX & 2007 & 131.920 & 66979 & 1.98E-03 & 1.244 & 627.7 & Beta \\
\hline UA & HTX & 2008 & 183.640 & 65370 & 2.73E-03 & 0.678 & 247.5 & Beta \\
\hline UA & HTX & 2009 & 175.170 & 65542 & 2.60E-03 & 0.843 & 323.4 & Beta \\
\hline UA & HTX & 2010 & 124.630 & 66029 & 1.84E-03 & 0.739 & 400.5 & Beta \\
\hline UA & HTX & 2011 & 86.640 & 64211 & 1.29E-03 & 1.315 & 1014.8 & Beta \\
\hline UA & HTX & 2012 & 153.060 & 59810 & 2.37E-03 & 0.746 & 313.3 & Beta \\
\hline UA & HTX & 2013 & 265.530 & 62692 & $3.90 \mathrm{E}-03$ & 0.722 & 184.4 & Beta \\
\hline UA & HTX & 2014 & 222.370 & 62876 & 3.38E-03 & 0.840 & 247.7 & Beta \\
\hline UA & MDP & 2002 & 6757.020 & 1181635 & 5.77E-03 & 1.440 & 248.2 & Beta \\
\hline UA & MDP & 2003 & 9903.722 & 1694959 & 5.80E-03 & 1.479 & 253.4 & Beta \\
\hline UA & MDP & 2004 & 8834.132 & 1823048 & 4.78E-03 & 1.669 & 347.6 & Beta \\
\hline UA & MDP & 2005 & 9412.642 & 1786052 & 5.13E-03 & 2.002 & 388.7 & Beta \\
\hline UA & MDP & 2006 & 8511.063 & 1823976 & 4.54E-03 & 1.467 & 321.4 & Beta \\
\hline UA & MDP & 2007 & 8779.190 & 1812695 & 4.67E-03 & 1.392 & 296.5 & Beta \\
\hline UA & MDP & 2008 & 9328.030 & 1816209 & 5.11E-03 & 2.092 & 407.3 & Beta \\
\hline UA & MDP & 2009 & 10380.670 & 1816116 & 5.45E-03 & 1.829 & 333.5 & Beta \\
\hline UA & MDP & 2010 & 10181.760 & 1788704 & 5.48E-03 & 1.904 & 345.3 & Beta \\
\hline UA & MDP & 2011 & 9126.340 & 1756809 & 5.09E-03 & 1.857 & 362.9 & Beta \\
\hline UA & MDP & 2012 & 9675.660 & 1733064 & 5.23E-03 & 1.597 & 303.9 & Beta \\
\hline UA & MDP & 2013 & 9731.110 & 1702603 & 5.24E-03 & 1.438 & 273.1 & Beta \\
\hline UA & MDP & 2014 & 10079.140 & 1748918 & 5.30E-03 & 1.224 & 229.8 & Beta \\
\hline
\end{tabular}


Table 13. Failure mode acronyms.

\begin{tabular}{ll}
\multicolumn{1}{c}{ Failure Mode } & \multicolumn{1}{c}{ Failure Mode Description } \\
\hline FTOC & Fail to open/close \\
FTOP & Fail to operate \\
FTR & Fail to run \\
FTR $>1 \mathrm{H}$ & Fail to run more than one hour (standby) \\
FTR $<1 \mathrm{H}$ & Fail to run less than one hour \\
FTS & Fail to start \\
LOHT & Loss of heat transfer \\
SO & Spurious operation \\
UA & Unavailability (maintenance or state of another component) \\
\hline
\end{tabular}


System Study

Residual Heat Removal
2014 Update December 2015 


\section{SYSTEM DESCRIPTION}

Being a multipurpose system, RHR provides many important functional configurations generally known as modes of operation. The different modes of RHR operation can include

- Low Pressure Coolant/Safety Injection

- Shutdown Cooling

- Suppression Pool Cooling (SPC) or Containment Sump Recirculation

- Containment Spray

- Fuel Pool Cooling.

The fundamental differences between plants can be summarized as some plants have dedicated shutdown-cooling systems, plants either use an intermediate closed cooling system or use a direct heat sink source of cooling to the RHR heat exchangers, plants have differing number of pumps (from 2 to 4 ), and the loop suction valve configuration is a single path with two valves or there are multiple paths. The RHR configurations at each plant are shown in Table 14. Figure 27 shows a generic depiction of a RHR system.

\subsection{Low Pressure Injection Mode}

The low-pressure injection (LPI) mode of the RHR system is primarily designed to mitigate the loss of coolant accidents (large and medium). During the injection phase of operation following a large LOCA, the RHR operates as an open-loop system and provides rapid injection of coolant to the primary system to ensure reactor shutdown and adequate core cooling. LPI operation is initiated automatically.

Considering the above process, LPI operation requires

- Opening discharge valves (AOV or MOV)

- Starting and running one or more RHR pumps

Either offsite or onsite emergency power may be used to operate RHR pumps and valves.

\subsection{Shutdown Cooling Mode}

For the SDC mode of the RHR system, the flow path is different from LPI and SPC or containment sump recirculation in that the suction source is the reactor via the reactor recirculation line or hot leg. From the recirculation line or the hot legs, water flows through two motor-operated isolation valves in series, the first being located inside containment while the second is outside containment. This is then followed by individual suction isolation valves for each train, then to the suction of each pump.

The RHR system in SDC mode removes fission product decay heat from the reactor core and sensible heat from RCS components during system cooldowns and at cold shutdown. The design pressure limits for the RHR system are lower than the RCS, so the system is isolated from the RCS during power operation. During RCS cooldowns to cold shutdown, the RHR system remains isolated until RCS temperature and pressure are below interlock setpoints.

SDC is not automatic. The RHR system is cold relative to the RCS, so RHR components must undergo a heatup process prior to use. RHR heat transfer (RCS cooldown) is controlled by heat exchanger cooling water valve adjustment.

Considering the above process, SDC operation requires

- Opening suction and discharge valves (AOV or MOV) 
- Starting and running one or more RHR pumps

- Establishing cooling water flow to the RHR heat exchanger

- Isolating the heat exchanger bypass

- Flow control through minimum flow valves

- Flow control of cooling water.

Either offsite or onsite emergency power may be used to operate RHR pumps and valves.

Two basic types of heat sinks are used at U.S. commercial nuclear power plants. The first is referred to here as a direct heat sink and the second is referred to here as an intermediate heat sink:

Direct Heat Sink - The direct heat sink generally uses a standby service water system to provide the heat sink for shutdown cooling. In some plants this is a dedicated residual heat removal service water system; in other plants, the emergency service water system is used. Either way, since the system is in standby, the pumps must be started to provide cooling.

Indirect Heat Sink-The plants with an indirect heat sink use a closed cooling water system such as the reactor building closed cooling water system as the first heat removal provider. The heat is ultimately removed by a normally running service water system. The main purpose of the intermediate cooling water system is to provide a barrier to the release of radioactive liquid to the environment. 
Residual Heat Removal System

From the $\mathrm{A}$

recirculation loop

(BWRs) or the

Minimum flow to

hot leg (PWRs)

suppression pool (BWR)

To the $B$ recirculation loop

(BWRs) or the cold leg

(PWRs)

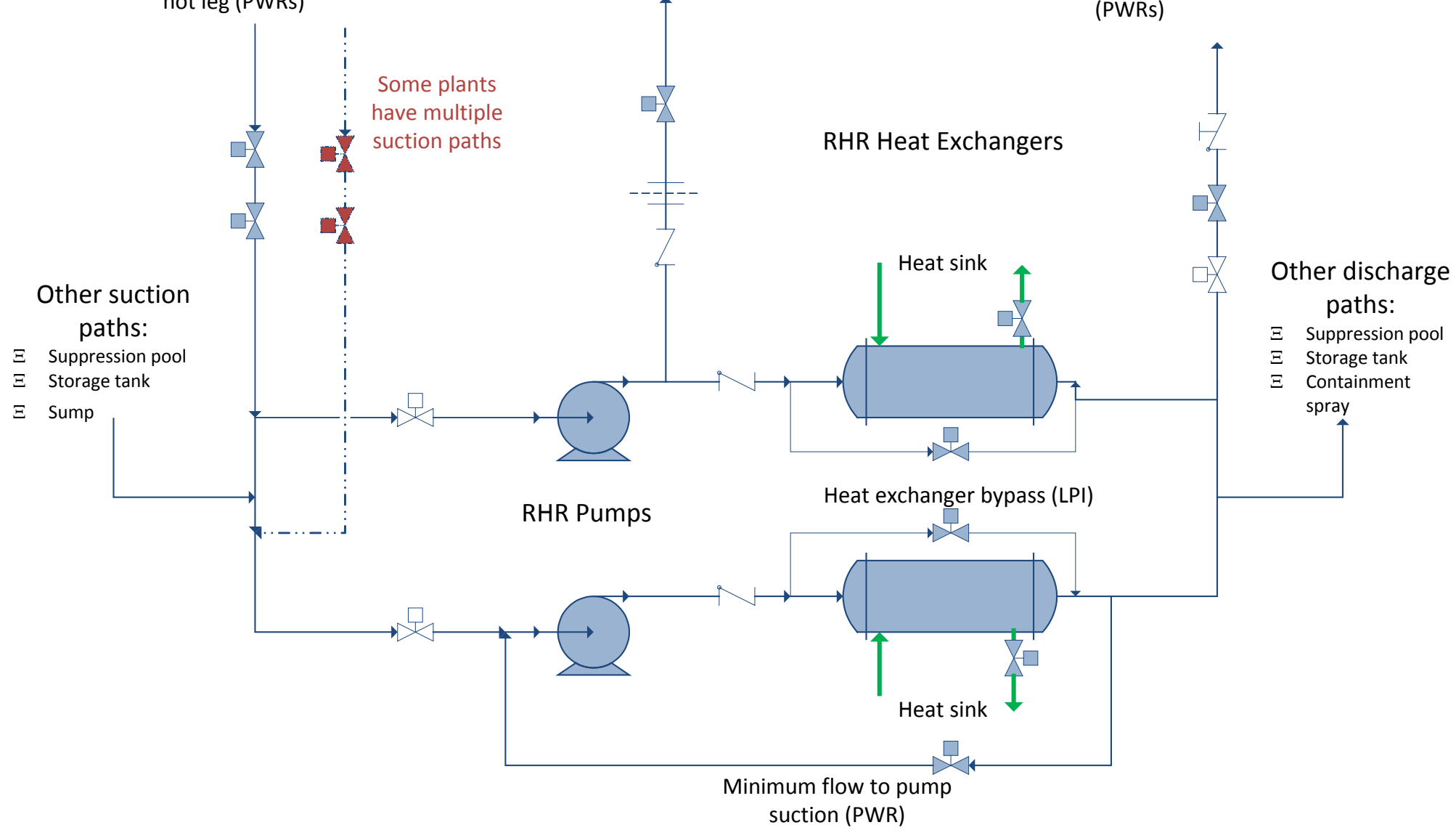

Figure 27. Generic depiction of the RHR system. 
Table 14. Listing of the RHR design classes. ${ }^{a}$

\begin{tabular}{|c|c|c|c|c|c|c|c|c|}
\hline Plant & Vendor & $\begin{array}{l}\text { LPI } \\
\text { Tree }\end{array}$ & $\begin{array}{l}\text { SDC } \\
\text { Tree }^{b}\end{array}$ & $\begin{array}{c}\text { BWR } \\
\text { Containment }\end{array}$ & $\begin{array}{l}\text { BWR } \\
\text { Design }\end{array}$ & $\begin{array}{l}\text { PWR } \\
\text { Loops }\end{array}$ & $\begin{array}{l}\text { Shutdown } \\
\text { Cooling Class }\end{array}$ & $\begin{array}{l}\text { Injection } \\
\text { Class }\end{array}$ \\
\hline Arkansas 1 & BW & LPI & DHR & & & 2 & Direct-Single & 2 pumps; BW \\
\hline Arkansas 2 & CE & LPI & SDC & & & 2 & Direct-Single & 2 pumps; CE \\
\hline Beaver Valley 1 & WE & LPI & RHR & & & 3 & Single Use & 2 pumps; WE \\
\hline Beaver Valley 2 & WE & LPI & RHR & & & 3 & Single Use & 2 pumps; WE \\
\hline Braidwood 1 & WE & LPI & RHR & & & 4 & Indirect-Multiple & 2 pumps; WE \\
\hline Braidwood 2 & WE & LPI & RHR & & & 4 & Indirect-Multiple & 2 pumps; WE \\
\hline Browns Ferry 1 & GE & $\mathrm{LCl}$ & SDC & MARK I & B-CLASS 4 & & Direct-Single & 4 pumps; GE \\
\hline Browns Ferry 2 & GE & $\mathrm{LCl}$ & SDC & MARK I & B-CLASS 4 & & Direct-Single & 4 pumps; GE \\
\hline Browns Ferry 3 & GE & $\mathrm{LCl}$ & SDC & MARK I & B-CLASS 4 & & Direct-Single & 4 pumps; GE \\
\hline Brunswick 1 & GE & LCl & SDC & MARK I(C) & B-CLASS 4 & & Direct-Single & 4 pumps; GE \\
\hline Brunswick 2 & GE & $\mathrm{LCl}$ & SDC & MARK I(C) & B-CLASS 4 & & Direct-Single & 4 pumps; GE \\
\hline Byron 1 & WE & LPI & RHR & & & 4 & Indirect-Multiple & 2 pumps; WE \\
\hline Byron 2 & WE & LPI & RHR & & & 4 & Indirect-Multiple & 2 pumps; WE \\
\hline Callaway & WE & LPI & RHR & & SNUPPS & 4 & Indirect-Multiple & 2 pumps; WE \\
\hline Calvert Cliffs 1 & CE & LPI & SDC & & & 2 & Indirect-Single & 2 pumps; CE \\
\hline Calvert Cliffs 2 & CE & LPI & SDC & & & 2 & Indirect-Single & 2 pumps; CE \\
\hline Catawba 1 & WE & LPI & RHR & & & 4 & Indirect-Single & 2 pumps; WE \\
\hline Catawba 2 & WE & LPI & RHR & & & 4 & Indirect-Single & 2 pumps; WE \\
\hline Clinton 1 & GE & $\mathrm{LCl}$ & SDC & MARK III(C) & B-CLASS 6 & & Direct-Single & 2 pumps; GE \\
\hline Columbia 2 & GE & LCl & SDC & MARK II & B-CLASS 5 & & Direct-Single & 2 pumps; GE \\
\hline Comanche Peak 1 & WE & LPI & RHR & & & 4 & Indirect-Multiple & 2 pumps; WE \\
\hline Comanche Peak 2 & WE & LPI & RHR & & & 4 & Indirect-Multiple & 2 pumps; WE \\
\hline Cook 1 & WE & LPI & RHR & & & 4 & Indirect-Single & 2 pumps; WE \\
\hline Cook 2 & WE & LPI & RHR & & & 4 & Indirect-Single & 2 pumps; WE \\
\hline Cooper & GE & $\mathrm{LCl}$ & SDC & MARK I & B-CLASS 4 & & Direct-Single & 4 pumps; GE \\
\hline Crystal River 3 & BW & LPI & DHR & & & 2 & Direct-Single & 2 pumps; BW \\
\hline Davis-Besse & BW & LPI & DHR & & & 2 & Indirect-Single & 2 pumps; BW \\
\hline Diablo Canyon 1 & WE & LPI & RHR & & & 4 & Indirect-Single & 2 pumps; WE \\
\hline Diablo Canyon 2 & WE & LPI & RHR & & & 4 & Indirect-Single & 2 pumps; WE \\
\hline Dresden 2 & GE & LCl & SDC & MARK I & B-CLASS 3 & & Single Use & 3 pumps; GE \\
\hline Dresden 3 & GE & $\mathrm{LCl}$ & SDC & MARK I & B-CLASS 3 & & Single Use & 3 pumps; GE \\
\hline Duane Arnold & GE & LCl & SDC & MARK I & B-CLASS 4 & & Direct-Single & 4 pumps; GE \\
\hline Farley 1 & WE & LPI & RHR & & & 3 & Indirect-Multiple & 2 pumps; WE \\
\hline Farley 2 & WE & LPI & RHR & & & 3 & Indirect-Multiple & 2 pumps; WE \\
\hline Fermi 2 & GE & $\mathrm{LCl}$ & SDC & MARK I & B-CLASS 4 & & Direct-Single & 4 pumps; GE \\
\hline FitzPatrick & GE & $\mathrm{LCl}$ & SPC & MARK I & B-CLASS 4 & & $\begin{array}{l}\text { No suction } \\
\text { modeled }\end{array}$ & 4 pumps; GE \\
\hline Fort Calhoun & CE & LPI & SDC & & & 2 & Indirect-Single & 2 pumps; CE \\
\hline Ginna & WE & LPI & RHR & & & 2 & Indirect-Single & 2 pumps; WE \\
\hline Grand Gulf & GE & $\mathrm{LCl}$ & SDC & MARK III(C) & B-CLASS 6 & & Direct-Single & 2 pumps; GE \\
\hline Harris & WE & LPI & RHR & & & 3 & Indirect-Multiple & 2 pumps; WE \\
\hline Hatch 1 & GE & $\mathrm{LCl}$ & SDC & MARK I & B-CLASS 4 & & Direct-Single & 4 pumps; GE \\
\hline Hatch 2 & GE & LCl & SDC & MARK I & B-CLASS 4 & & Direct-Single & 4 pumps; GE \\
\hline Hope Creek & GE & $\mathrm{LCl}$ & SDC & MARK I & B-CLASS 4 & & Direct-Single & 2 pumps; GE \\
\hline Indian Point 2 & WE & LPI & RHR & & & 4 & Indirect-Single & 2 pumps; WE \\
\hline
\end{tabular}


Table 14. (continued).

\begin{tabular}{|c|c|c|c|c|c|c|c|c|}
\hline Plant & Vendor & $\begin{array}{l}\text { LPI } \\
\text { Tree }\end{array}$ & $\begin{array}{l}\text { SDC } \\
\text { Tree }^{b}\end{array}$ & $\begin{array}{c}\text { BWR } \\
\text { Containment }\end{array}$ & $\begin{array}{l}\text { BWR } \\
\text { Design }\end{array}$ & $\begin{array}{l}\text { PWR } \\
\text { Loops }\end{array}$ & $\begin{array}{l}\text { Shutdown } \\
\text { Cooling Class }\end{array}$ & $\begin{array}{l}\text { Injection } \\
\text { Class }\end{array}$ \\
\hline Indian Point 3 & WE & LPI & RHR & & & 4 & Indirect-Single & 2 pumps; WE \\
\hline Kewaunee & WE & LPI & RHR & & & 2 & Indirect-Multiple & 2 pumps; WE \\
\hline La Salle 1 & GE & $\mathrm{LCl}$ & SDC & MARK II(C) & B-CLASS 5 & & Direct-Single & 2 pumps; GE \\
\hline La Salle 2 & GE & LCl & SDC & MARK II(C) & B-CLASS 5 & & Direct-Single & 2 pumps; GE \\
\hline Limerick 1 & GE & $\mathrm{LCl}$ & SDC & MARK II(C) & B-CLASS 4 & & Direct-Single & 4 pumps; GE \\
\hline Limerick 2 & GE & $\mathrm{LCl}$ & SDC & MARK II(C) & B-CLASS 4 & & Direct-Single & 4 pumps; GE \\
\hline McGuire 1 & WE & LPI & RHR & & & 4 & Indirect-Single & 2 pumps; WE \\
\hline McGuire 2 & WE & LPI & RHR & & & 4 & Indirect-Single & 2 pumps; WE \\
\hline Millstone 2 & CE & LPI & SDC & & & 2 & Indirect-Single & 2 pumps; CE \\
\hline Millstone 3 & WE & LPI & RHR & & & 4 & Indirect-Multiple & 2 pumps; WE \\
\hline Monticello & GE & $\mathrm{LCl}$ & SDC & MARK I & B-CLASS 3 & & Direct-Single & 4 pumps; GE \\
\hline Nine Mile Pt. 1 & GE & LCS & SDC & MARK I & B-CLASS 2 & & Single Use & 3 pumps; GE \\
\hline Nine Mile Pt. 2 & GE & LCl & SDC & MARK II(C) & B-CLASS 5 & & Direct-Single & 2 pumps; GE \\
\hline North Anna 1 & WE & LPI & RHR & & & 3 & Single Use & 2 pumps; WE \\
\hline North Anna 2 & WE & LPI & RHR & & & 3 & Single Use & 2 pumps; WE \\
\hline Oconee 1 & BW & LPI & DHR & & & 2 & Indirect-Single & 3 pumps; BW \\
\hline Oconee 2 & BW & LPI & DHR & & & 2 & Indirect-Single & 3 pumps; BW \\
\hline Oconee 3 & BW & LPI & DHR & & & 2 & Indirect-Single & 3 pumps; BW \\
\hline Oyster Creek & GE & LCl & SDC & MARK I & B-CLASS 2 & & Single Use & 3 pumps; GE \\
\hline Palisades & CE & LPI & SDC & & & 2 & Indirect-Single & 2 pumps; CE \\
\hline Palo Verde 1 & CE & LPI & SDC & & SYSTEM 80 & 2 & Direct-Multiple & 4 pumps; CE \\
\hline Palo Verde 2 & CE & LPI & SDC & & SYSTEM 80 & 2 & Direct-Multiple & 4 pumps; CE \\
\hline Palo Verde 3 & CE & LPI & SDC & & SYSTEM 80 & 2 & Direct-Multiple & 4 pumps; CE \\
\hline Peach Bottom 2 & GE & LCl & SDC & MARK I & B-CLASS 4 & & Direct-Single & 4 pumps; GE \\
\hline Peach Bottom 3 & GE & LCl & SDC & MARK I & B-CLASS 4 & & Direct-Single & 4 pumps; GE \\
\hline Perry & GE & LCl & SDC & MARK III & B-CLASS 6 & & Indirect-Single & 2 pumps; GE \\
\hline Pilgrim & GE & LCl & SPC & MARK I & B-CLASS 3 & & $\begin{array}{l}\text { No suction } \\
\text { modeled }\end{array}$ & 4 pumps; GE \\
\hline Point Beach 1 & WE & LPI & RHR & & & 2 & Indirect-Single & 2 pumps; WE \\
\hline Point Beach 2 & WE & LPI & RHR & & & 2 & Indirect-Single & 2 pumps; WE \\
\hline Prairie Island 1 & WE & LPI & RHR & & & 2 & Direct-Multiple & 2 pumps; WE \\
\hline Prairie Island 2 & WE & LPI & RHR & & & 2 & Direct-Multiple & 2 pumps; WE \\
\hline Quad Cities 1 & GE & LCl & SDC & MARK I & B-CLASS 3 & & Direct-Single & 4 pumps; GE \\
\hline Quad Cities 2 & GE & LCl & SDC & MARK I & B-CLASS 3 & & Direct-Single & 4 pumps; GE \\
\hline River Bend & GE & LCl & SDC & MARK III & B-CLASS 6 & & Direct-Single & 2 pumps; GE \\
\hline Robinson 2 & WE & LPI & RHR & & & 3 & Indirect-Single & 2 pumps; WE \\
\hline Salem 1 & WE & LPI & RHR & & & 4 & Indirect-Single & 2 pumps; WE \\
\hline Salem 2 & WE & LPI & RHR & & & 4 & Indirect-Single & 2 pumps; WE \\
\hline San Onofre 2 & CE & LPI & SDC & & & 2 & Indirect-Multiple & 2 pumps; CE \\
\hline San Onofre 3 & CE & LPI & SDC & & & 2 & Indirect-Multiple & 2 pumps; CE \\
\hline Seabrook & WE & LPI & RHR & & & 4 & Indirect-Multiple & 2 pumps; WE \\
\hline Sequoyah 1 & WE & LPI & RHR & & & 4 & Indirect-Single & 2 pumps; WE \\
\hline Sequoyah 2 & WE & LPI & RHR & & & 4 & Indirect-Single & 2 pumps; WE \\
\hline South Texas 1 & WE & LPI & RHR & & & 4 & Indirect-Multiple & 3 pumps; WE \\
\hline South Texas 2 & WE & LPI & RHR & & & 4 & Indirect-Multiple & 3 pumps; WE \\
\hline St. Lucie 1 & CE & LPI & SDC & & & 2 & Indirect-Multiple & 2 pumps; CE \\
\hline
\end{tabular}


Table 14. (continued).

\begin{tabular}{|c|c|c|c|c|c|c|c|c|}
\hline Plant & Vendor & $\begin{array}{l}\text { LPI } \\
\text { Tree }\end{array}$ & $\begin{array}{l}\text { SDC } \\
\text { Tree }^{b}\end{array}$ & $\begin{array}{l}\text { BWR } \\
\text { Containment }\end{array}$ & $\begin{array}{l}\text { BWR } \\
\text { Design }\end{array}$ & $\begin{array}{l}\text { PWR } \\
\text { Loops }\end{array}$ & $\begin{array}{l}\text { Shutdown } \\
\text { Cooling Class }\end{array}$ & $\begin{array}{l}\text { Injection } \\
\text { Class }\end{array}$ \\
\hline St. Lucie 2 & CE & LPI & SDC & & $2 \mathrm{HL} / 4 \mathrm{CL}$ & 2 & Indirect-Multiple & 2 pumps; CE \\
\hline Summer & WE & LPI & RHR & & & 3 & Indirect-Multiple & 2 pumps; WE \\
\hline Surry 1 & WE & LPI & RHR & & & 3 & Single Use & 2 pumps; WE \\
\hline Surry 2 & WE & LPI & RHR & & & 3 & Single Use & 2 pumps; WE \\
\hline Susquehanna 1 & GE & $\mathrm{LCl}$ & SPC & MARK II(C) & B-CLASS 4 & & $\begin{array}{l}\text { No suction } \\
\text { modeled }\end{array}$ & 4 pumps; GE \\
\hline Susquehanna 2 & GE & $\mathrm{LCl}$ & SPC & MARK II(C) & B-CLASS 4 & & $\begin{array}{l}\text { No suction } \\
\text { modeled }\end{array}$ & 4 pumps; GE \\
\hline Three Mile IsI 1 & BW & LPI & DHR & & & 2 & Single Train & 2 pumps; BW \\
\hline Turkey Point 3 & WE & LPI & RHR & & & 3 & Indirect-Single & 2 pumps; WE \\
\hline Turkey Point 4 & WE & LPI & RHR & & & 3 & Indirect-Single & 2 pumps; WE \\
\hline Vermont Yankee & GE & $\mathrm{LCl}$ & SDC & MARK I & B-CLASS 4 & & Direct-Single & 4 pumps; GE \\
\hline Vogtle 1 & WE & LPI & RHR & & & 4 & Indirect-Multiple & 2 pumps; WE \\
\hline Vogtle 2 & WE & LPI & RHR & & & 4 & Indirect-Multiple & 2 pumps; WE \\
\hline Waterford 3 & CE & LPI & SDC & & $2 \mathrm{HL} / 4 \mathrm{CL}$ & 2 & Indirect-Multiple & 2 pumps; CE \\
\hline Watts Bar 1 & WE & LPI & RHR & & & 4 & Indirect-Single & 2 pumps; WE \\
\hline Wolf Creek & WE & LPI & RHR & & SNUPPS & 4 & Indirect-Multiple & 2 pumps; WE \\
\hline \multicolumn{9}{|c|}{$\begin{array}{l}\text { a. Nuclear Regulatory Commission, Overview and Comparison of U.S. Commercial Nuclear Power Plants, } \\
\text { NUREG/CR-5640, SAIC-89/1541, September } 1990 .\end{array}$} \\
\hline
\end{tabular}




\section{REFERENCES}

1. Nuclear Regulatory Commission, Component Reliability Data Sheets Update 2010, January 2012, http://nrcoe.inl.gov/resultsdb/publicdocs/AvgPerf/ComponentReliabilityDataSheets2010.pdf

2. S.A. Eide et al., Industry-Average Performance for Components and Initiating Events at U.S. Commercial Nuclear Power Plants, Nuclear Regulatory Commission, NUREG/CR-6928, February 2007. 